\title{
The Development of a Moroccan Merchant Colony (1767-1799)
}

We have already seen how the peace treaties signed by the Spanish monarchy with Morocco, the North African Regencies, and the Ottoman Empire favored increased trade among all parties. As a result a significant colony of Muslim (especially Moroccan) merchants began to form in several Spanish ports and other cities. In the almost half century between 1767 and 1814 we can identify three distinct periods. During the first, $1767-178$ o, we find records of the initial experiences of Moroccan merchants on Spanish soil. During the second, between the Aranjuez Agreement of 1780 and the Spanish-English war of 17791783, a permanent colony of Moroccan merchants was consolidated in Spain. The third ran from the Spanish-Moroccan Peace Treaty of 1799 to 1814, the end of the Napoleonic invasion of Spain; during this time Spain attracted, in addition to Moroccans, many Algerian, Tunisian, and Tripolitan ship captains, pursers, and merchants. In this chapter we shall analyze the first two of these periods, leaving the third to Chapter 9 .

\subsection{Gradual Appearance of Moroccan Merchants in Spain (1767-1780)}

The Treaty of Peace, Friendship, and Trade that Spain and Morocco signed in ${ }_{1767}$ included a series of articles intended to regulate the presence and activity of merchant and trading vessels of each country in ports of the other. The treaty was clearly written in a spirit of reciprocity, but - as had happened ever since Europeans first made pacts with Islamic lands in the Middle Ages and Early Modern era - emphasis fell on how Europeans would be treated in Muslim countries. In the Spanish case, while the rights of Spanish subjects were spelled out in minute detail, articles would conclude with a phrase such as "[in Spain], Spaniards shall do likewise toward Moors." 1 This asymmetry translated into an obvious lack of interest in the fate of Muslim seamen and traders in Spanish domains.

1 Cantillo, Tratados, 505-06. 
The situation should not be surprising if we consider that North African nations lacked true merchant marine fleets, and that very few of their merchants could engage in international trade. ${ }^{2}$ Besides, Spanish authorities (through their consulate in Tangier and the Secretariat of State) threw up continuous obstacles to the arrival of Moroccans in Spanish ports. Therefore our sources contain little information about the presence of Moroccan traders in Spain.

Article 5 of the Treaty of 1767 guaranteed the right of trade and sea travel between the two countries and respect for each others' flags:

Free trade is permitted between the two nations, as well as travel by sea from one to the other: any vessel may be in any port it wishes, and the vassals of each power may, without interference from anyone, buy and sell the goods they wish, as they wish, and wherever it suits them, even in the interior of each country, except when the goods are contraband.

By Article 2, merchant ships as well as warships had to carry the proper passports. Article 4 stipulated that ships wrecked on the coasts would be assisted in the rescue of crew members, cargoes, and the ships themselves if possible:

Those that are lost on the coasts of the other shall be treated with all proper hospitality, managing if possible to save the ships and giving them the aid they ask for, without that work being charged or arranged for at more than its fair price.

According to Article 14, ships should serve a quarantine if there was any uncertainty about health conditions in Morocco:

Any vessel of His Imperial Majesty that crosses to a port in Spain shall serve the stipulated quarantine unless the consuls have provided a perfect bill of health, in which case they shall be exempt from it.

The total liberty of one country's citizens in the other nation was guaranteed by Article 11:

2 Lourido Díaz, Marruecos y el mundo exterior, 99-112. 
Every Spaniard in the domains of His Imperial Majesty, and every vassal of the latter in the kingdoms of His Catholic Majesty, shall be free, whatever the motive that has brought him there. ${ }^{3}$

At the same time, Article 6 fixed "in perpetuity the duties of import and export that commerce must pay," including anchorage fees.

To facilitate Spanish commercial activity a consulate and vice consulate were established in Morocco, but the text (at Article 7) makes no reference to parallel institutions of Morocco's in Spain. Article 13 merely protected the property of Moroccans who died on Spanish soil:

Spanish authorities shall preserve the goods of Moors who die there until His Imperial Majesty, having been informed, makes disposition of them; unless the legitimate heir is not present, in which case [His Majesty] shall be given everything unless the deceased has decided otherwise in his will. ${ }^{4}$

Clearly the Treaty of 1767 paid little attention to strictly economic issues: it concentrated on enhancing the activity of ships that flew the Spanish flag, while that of Moroccan vessels was an afterthought. Bearing all this in mind we shall now investigate the presence and settlement of the first Moroccan merchants in Cádiz and other Spanish ports, as well as the litigation and other conflicts they were involved in and what kinds of solutions they attempted.

3 [Article 5]: "Se permite un comercio libre entre ambas naciones, así como la navegacion de un país a otro: cualquiera embarcación ha de poder estar en los puertos que quisiere, y los vasallos de una y otra potencia podrán, sin que se entrometa en ello otro alguno, comprar y vender los géneros que quisieren, como quisieren y donde les convenga, aunque sea en lo interior de los reinos, exceptuando los que fueren de contrabando." [4]: "Los que se perdieren en las costas recíprocas serán tratados con toda buena hospitalidad, procurando, si fuere posible, salvar las embarcaciones, y dándoles auxilios que para ello pidieren, sin pagarse los trabajos ó lo que se franqueare mas que por sus justos precios." [14]: "Cualquier embarcación de su Majestad imperial que pase a los puertos de España habrá de hacer la cuarentena estipulada, a menos que los cónsules no la hayan dado el seguro de una perfecta sanidad, pues en tal caso se eximirán de hacerla." [11]: “Todo español en los dominios de su Majestad imperial, y todo vasallo de este en los reinos de su Majestad católica será libre cualquiera que sea el motivo que á ellos les hubiera conducido." Lourido Díaz, Marruecos y el mundo; Rodríguez Casado, Política Marroqui de Carlos III; Conrotte, España y los países musulmanes.

4 "Las justicias de España custodiaran los bienes de los moros que allí murieren, hasta que dando aviso disponga su Majestad imperial de ellos; a menos que no se halle presente el legítimo heredero, pues en tal caso se le entregara el todo, ó que en el testamento hubiere dispuesto otra cosa el difunto": Cantillo, Tratados, 505-07. 
Our sources yield little about these Moroccans, perhaps in part because of the nature of document collections, which privilege diplomatic issues over commercial ones. Further, the Spanish-Moroccan war of 1774-1775 doubtless inhibited the settlement of Moroccans in Spain. Our information for the period $1767-178$ o is therefore meager.

Few Moroccans would have dared to cross the Strait and enter a trade dominated by experienced European merchants in general, and Spaniards in particular. Perhaps we hear so little about them because their activities caused no conflicts worthy of documentation. Still, a few enterprising individuals tried to take advantage of each side's relative ignorance of the other, as we will see through the cases of Abraham Beniso and Sidi Mohamed Benhamet Sherif.

\subsubsection{Abraham Beniso, a Clever and Wily Adventurer (1768)}

On 25 April 1768 the royal magistrate (corregidor) of the Vizcaya region in the Basque country, Juan Domingo de Junco, wrote to Secretary of State Grimaldi that Abraham Ben Meshud "Biniso" had come to Bilbao the day before: "last night just after dusk that individual arrived in our city, with an introduction from the Count of Fuentes in Paris." ${ }^{5}$

The magistrate issued orders to "the inns and lodging-houses to report at once the arrival of the commissioner from the Emperor of Morocco." On learning that he had lodged at the Posada del León, he sent a trusted associate to gather more information. Beniso, who boasted of knowing how Basque ports might engage in trade with Morocco, proposed that

he needed to meet the authorities of this town and deal with some merchants or the head of the consular service; for which purpose, going far out of his way, he came under express orders from his sovereign to this city because it combined all the advantages of France, England, and Holland through the valuable and abundant iron that is shipped from this harbor to the Empire of Morocco. His master the Emperor is very pleased with the peace concluded with Spain, and wishes to transfer there all the useful goods produced in his vast, opulent empire; but especially to this city, whose merchants he will favor with a reduction of two percent in the duties that are required in that empire.

5 Spain's ambassador to Paris at the time was Joaquín Atanasio de Pignatelli, Count of Fuentes. Abraham's surname appears regularly as both Biniso and Beniso in the sources. Juan Domingo de Junco to Marquis of Grimaldi, Bilbao, 25 April 1768, A HN, Estado, leg. 5803, Exp. 5 . 
He added that every year "forty or fifty French, English, and Dutch vessels averaging five hundred tons among large and small ones" arrived in Moroccan ports "all laden with iron from this region." When asked what products Morocco might provide in return he spoke of "silk, leather, rare furs, dried fruits, almonds, and many other items." 6

Beniso showed a series of passports and claimed that France was less than pleased with the Hispano-Moroccan treaty of 1767 ("in France he had detected jealousy of Spain's peace treaty with his sovereign, and was sometimes treated coldly"). He thought there was suspicion of the treaty in Great Britain as well ("it embitters them even more") because it weakened the defense of Gibraltar: "since [the English] are always importing food from Morocco, if Spain were to lay seige to [Gibraltar] the Empire would never provide it." He ended by reiterating that "his master wishes to reserve the rights of chartering, commissions, returns, and a two-percent advantage in duties to be reserved for tradesmen from this city."7

On the very day he arrived Beniso wrote to the corregidor explaining his objectives in misspelled Spanish:

Today, 24 April 1768, I have arrived in this city of Bilboa [sic] bearing a letter from His Imperial Majesty the Emperor of Morocco, in which letter His Imperial Majesty says that all those who wish to come from Bilboa to trade, or who send their goods to the ports of Mogador and Larache, will be welcomed with their possessions, ships, etc. And from the day that persons from this city arrive in those two ports, they and their possessions will be safe until the day that they wish to return to their country, and will suffer no loss in the Kingdom of Morocco. His Imperial Majesty says in his letter that all who come or send their goods, whether with me or privately, from the day they set foot in those ports shall be safe and protected, with their belongings, until they return home

6 “...necesitaba verse con las justicias de este Pueblo, y tratar con algunos Comerciantes, ó con la Cabeza de el Consulado, a cuyo fin, perdiendo mucho camino, venia con orden expresa de su Soberano a esta villa, la que tenia ocasión de unir en si totas las utilidades, que sacan la Francia, Ynglaterra y Olanda con el precioso abundante fierro, que embarcan en esta ria, para el Ymperio de Marruecos; que el Emperador su Amo se halla mui gustoso con la paz concluida con la España, y quiere trasladar a ella todas las utilidades, que produce su vasto opulento Ymperio, pero con especialidad a esta Villa, a cuyos Comercian[t]es les distinguirá con la equidad de dos por ciento en los derechos, que se exijen en aquel Ymperio." For imports from Spain see Koehler, "Ce que l'économie privée importait d'Espagne."

7 Undated and unsigned document, undoubtedly by Domingo de Junco, AHN, Estado, leg. 5803 , Exp. 5 . 
in peace. In a second letter His Majesty orders me to send or bring from here master masons who know how to build towers, etc.; and since this last point cannot be easily executed without the approval of the Spanish Court, I cannot undertake to do anything without first informing Your Highness. I hope that Your Excellency will honor me with a reply so that I can proceed. ${ }^{8}$

The next day Beniso called on the magistrate, but on not finding him asked that his petition be forwarded to Grimaldi, the Secretary of State: "since I am not acquainted with all the titles belonging to that gentleman I have taken the liberty of sending you a blank sheet to that you can address it properly." $\mathrm{He}$ also hoped to speak with the city's mayor, Domingo del Barco:

I was at the house of the Corregidor this morning and have conveyed part of my mission to him, so I am about to depart. I would be pleased if you could grant me an hour of your good company this afternoon or this evening to speak together, either at your house or at my inn, the León de Oro. ${ }^{10}$

"Oi 24 de Abril 1768 tengo allegado a esta Ciudad de Bilboa Encargado de una carta Real de su Magestad Ymperial el Emperador de Marruecos en la cual carta dice Su Magestad Ymperial, a todos los que de Bilboa quieran vinir a negociar o manden sus Bienes a los puertos de Mogdor y a Larache, que serán Bien vinidos elios sus haciendas, embarcaciones \&, y que desde el dia que allegaren algunos de esta Ciudad a los dichos dos puertos elios y sus haciendas serán en siguridad asta el dia que quisieren volverse a sus tierras sin que tengan ninguna perdida en el Reyno de Marruecos: Dise su Magestd Ymperiall en la dicha carta, que todos los que vinieren o mandaren sus efectos que sea en mi compaña si particular, que Desde el dia que pondrán pie en los dichos Puertos, serán siguros y protexedos Elios y sus Bienes asta qui bulvan a sus tierras en pas; Su magestad mi ordena en sigunda Carta que de aquí lieve o mandare algunos maestros albañiles que sepan hacer torres \&, y Como este ultimo punto no es fácil a cer executado sin aprobasion de la Corte de Espagna no puedo tomas sobre mi hacer nada sin premero dar parte a Vuestra Alteza, espero vuestra Excelencia mi honre con Respuesta par que pueda yo Governarme": Ben Meshud Biniso (who signs all his correspondence in Latin letters), 24 April 1768, AHN, Estado, leg. 5803, Exp. 5 .

9 "I have been at the Corregidor's home and have not had the pleasure of seeing His Excellency": A. Beniso to the mayor of Bilbao, 25 April 1768, AHN, Estado, leg. 5803, Exp. 5.

10 "Esta mañana he estado en caza del Sr. Corexedor y tengo comunicado a dicho Sr. parte de mi encargo, de modo que Estoi de partensia, y tuviera yo gusto el que VM mi conseda una hora de su buena compañía esta tarde ó de Noche para discurrir juntos, sea en su caza de Vm o en esta posada del Leon de Oro": A. Beniso to the mayor of Bilbao, 26 April 1768, AHN, Estado, leg. 5803, Exp. 5 . 
A separate note requested:

I hope that you and the Corregidor will be so good as to name an hour tomorrow so that the commission I bring from His Imperial Majesty the Emperor of Morocco my sovereign may be presented to the public, i.e., the Board of Trade. I have no other reason to tarry in this city, and I remain your obedient servant. ${ }^{11}$

Junco informed Grimaldi of Beniso's visit, describing him as "reluctant to appear in my presence, though he was of course informed that in this province I hold the highest post of any magistrate and without my permission he cannot carry out any of the plans he envisions." He did, however, let the mayor of Bilbao allow Beniso's proposals, "which he says come in the name of his sovereign the Emperor of Morocco," to be heard by the Board of Trade. When he called Beniso in for an interview, the Moroccan

showed him two letters that he said represented "credentials from his master" (these were his exact words). Since they were written in illegible letters and without any translation I did not feel that they had much authority. He brings a passport from the Count of Fuentes and another from the Spanish consul in Bordeaux, but he has not produced the letter Your Excellency mentions from Father Bartholomé Girón of the Concepción Monastery for the Redemption of Captives.

Junco and Grimaldi, after exchanging their information about Beniso, discovered that his real name was Abraham Chasolt and that he brought no letter of recommendation from Father Girón of the Spanish mission in Meknes. The magistrate, knowing that Beniso had already "been caught out in some inconsistencies in what he has said," forbade him to

engage in any business with the commission he claims to bring, unless our superiors have taken the necessary previous steps. And before I explained this to him I understand that he wrote to Your Excellency through the mailbag, after I had suggested that he introduce himself to you; but

11 "Estimare Vm sea servido en compañía del Sor. Corexidor apunten una hora mañana para que se presente al publico o Sea Camara de Comercio la comisión que traigo de parte de su magestad imperial el Emperador de Marruecos mi Suberano, no tengo otro motivo par dilitarme en Esta, siendo lo que si ofrece de su maior Servidor de Vm": A. Beniso to the mayor of Bilbao, 25 April 1768, AHN, Estado, leg. 5803, Exp. 5 . 
I later learned that he did not like my suggestion and says that he will leave this city very soon. ${ }^{12}$

In early May Domingo de Junco received word from Grimaldi in Aranjuez about the activities of "the commissioner from Morocco." The Count praised the magistrate's caution and urged him to remain vigilant until it were proved whether or not Beniso was actually an envoy of the sultan:

According to the first news we had from Paris we should have been suspicious of this individual, but later accounts have removed those doubts and presume that he is really a commissioner from Morocco. Nonetheless it will be best to observe his movements, his speech, the people he meets, and the means he uses, as well as his style of life.

Nothing is lost if merchants and natives of this country listen to what the commissioner tells them about trading they might do in the Kingdom of Morocco; it would be desirable if it could be established to our advantage; but in any case do not let incautious persons, carried away by promises and apparent benefits, risk their money in the hands of the commissioner.

So far the King of Morocco has not told us that this commissioner was coming; rather he has warned us to consider as an adventurer anyone who claims to be a commissioner without bringing a letter in the king's hand. For this reason - and because this commissioner has approached the authorities of one particular city and not the king or his ministry - it behooves Your Excellency to have your representative present him with these doubts as if they were your own, to see how he answers.

Grimaldi concluded by urging Junco to take "care and precautions so that this commissioner cannot defraud any subject of the king," while at the same

12 “...mostró dos cartas, que, dixo ser de creencia de su Amo (estas fueron sus mismas vozes) las que en caracteres ilegibles y sin la menor traducción, no me parecieron denotar la mayor auctoridad, trahe el pasaporte del señor Conde Fuentes, y también el de el Consul de la nación española de Burdeos, pero no ha mostrado la carta, que V.E. expresa dada por el P. Fr. Bartholome Giron de la Concepcion Redemptor de Cautivos. ... [que] hiciese aquí gestión alguna con la Comision que, dixo, trahía, sin que precediesen los pases correspondientes de nuestra Superioridad, y antes de hacer yo esta propuesta, me consta que se dirigió por la Balixa una carta suya a V.E. a quien, le incliné, se presentase; pero he sabido después, que no le ha quadrado mi proposición, y que dice saldrá de esta Villa mui en breve": Juan Domingo de Junco to Marquis of Grimaldi, Bilbao, 28 April 1768, AHN, Estado, leg. 5803. Exp. 5. 
time suggesting that, if possible, he "consider his ideas if they should be truly advantageous." ${ }^{13}$

A few days later, Junco informed Grimaldi that Beniso (whom he occasionally calls "Interpreter to the Emperor of Morocco") had asked him to arrange

to bring the whole [Board of] Trade together so that in my presence he can offer his proposals, which he claims are so useful, in the name of his master. And though I explained to him that in this city there are several English, Irish, and Dutch individuals he could deal with, he did not agree to this, much less to asking Your Excellency for the necessary consent so that his ideas could be heard.

Beniso, having been thwarted, took ship at Portugalete bound for Portugal. But he left behind, "in the hands of a confidant of his from this town, a paper for Your Excellency - who, I understand, did not wish to receive him privately - in which he explains certain dubious passages of the conversation he had with me." The magistrate defended himself saying that he had opposed not the project itself "but only the method by which he planned to carry it out."14

13 "Por las primeras noticias que tuvimos de Paris debía sernos sospechoso este sujeto pero posteriormente han venido otras que quitan aquellos recelos, y le suponen realmente Comisionado de Marruecos. Sin embargo conviene siempre observar sus pasos sus discursos, las gentes con quienes trata y los medios de que se vale, como también la vida que hace.

"Nada se pierde en que los comerciantes y naturales de este Pais tomen las luces que dicho comisionado les comunique sobre el comercio que pueden hacer en el Reino de Marruecos: $Y$ antes seria de desear que se estableciese con ventaja por nuestra parte; pero en todo caso no permita V.S. que algunos incautos llevados de promesas o de aparentes utilidades aventuren su dinero en manos del comisionado.

"Hasta ahora el Rey de Marruecos no ha dado aviso de que venia tal Comisionado: $\mathrm{Y}$ por el contrario tiene prevenido que se mire como aventurero a qualquiera que diga ser comisionado suyo si no trae carta de su puño. Por esto, y por ser notable que ese comisionado se dirija a las justicias de una ciudad en particular y no al Rey ó a su Ministerio, será mui conveniente que el Emisario de V.E. le proponga estas dudas como pensamiento propio para ver que responde": Aranjuez to Domingo de Junco, 2 May 1768, AHN, Estado, leg. 5803 . Exp. 5 .

14 “...[que] juntase el Comercio todo, para hacerle a mi presencia las proposiciones, que, dixo, trahia tan útiles en nombre de su Amo, y sin embargo de que le expuse, de que tendría en este Pueblo, como en efecto hay varios sujetos Yngleses, Yrlandeses y olandeses, con quienes podría tratar, no se acomodó a esto, y menos a solicitar de V.E. el consentimiento correspondiente, para que tubiessen efectos sus ideas": Juan Domingo del Junco to Marquis of Grimaldi, Bilbao, 6 May 1768, AHN, Estado, leg. 5803, Exp. 5. 
After a long delay Grimaldi replied to Beniso about the report he had sent him on reaching Bilbao. The Secretary of State did not recognize him as a commissioner from Morocco because he brought no letter from the sultan, as the sultan himself required. Besides, the conditions Beniso offered were the same privileges outlined in the Treaty of 1767 :

The King my master appreciates the King of Morocco's interest in favoring the residents of Bilbao, though the offers you make in your letter are the same ones that, as the Treaty of Peace stipulates, will be enjoyed in Morocco by all Spanish vassals who come from any province.

Allow me to remind you that you cannot be recognized as a commissioner from Morocco unless you present a letter from the king your master to [our] king, giving you authority. And besides this being the practice of all princes, the King of Morocco himself has particularly insisted upon it. Further, it is not normal for these commercial affairs to be negotiated with any one city, but rather directly with the king my master and his ministers. The king will enter with pleasure into anything that is of advantage to the two nations. ${ }^{15}$

In the meantime Juan Domingo del Junco had continued his inquiries about Beniso's movements in Bilbao. He heard "from a certain merchant of this town" who had

become friendly with the commissioner in order to learn his intentions and why he had come. And in refusing to answer him [Beniso] told the merchant that he would never tell him what he wanted to know. And that he was already aware that there might be an order from Madrid not to admit his proposals here, no matter how favorable, because in the Peace Treaty with his master the Emperor there was a specific

15 "[E]l Rey mi amo estima el cuidado con que el Rey de Marruecos quiere favorecer á los vecinos de Bilbao, aunque las ofertas que Vm hace en su citada carta son las mismas que en el Tratado de paz se estipula han de gozar en Marruecos todos los vasallos Españoles de qualquiera Provincia que sean. "Permita Vm que le advierta no se le puede reconocer por Comisionado de Marruecos mientras no presente una Carta del Rey su Amo para el Rey en que se le autorice: Y además de ser esta la practica de todos Principes, lo tiene particularmente encargado asi el mismo Rey de Marruecos. Tampoco es regular que estos negocios de comercio se traten en particular con ninguna ciudad, sino directamente con el Rey mi Amo, y sus Ministros. En todo lo que sea ventajoso a las dos Naciones entrará el rey mui gustoso": draft letter from Grimaldi to Beniso, Aranjuez, 9 May 1768, acknowledging receipt of Beniso's of 24 April: AHN, Estado, leg. 5803, Exp. 5 . 
exclusion of trade with these provinces, and therefore he would not stay here long.

Junco concluded that while no more had been heard from Beniso, "the traders in this region have had fair warning to avoid the evils that could arise from the promises of this individual, who seems to lack all authority"16

\subsubsection{A Trickster, Sidi Mohamet Benhamet Sherif(1769)}

In May 1769 a man from Tetouan named Sidi Mohamet Benhamet Sherif ${ }^{17}$ appeared in Madrid to complain about Jorge Cheret ${ }^{18}$ and Antonio Gómez, both of whom "seem to have formed a trading company with him in Larache, each investing a certain sum, and [he alleges] that they have not fulfilled the obligations they assumed." As proof Benhamet brought a letter from Tomás Bremond, the Spanish consul general in Larache, and another from the governor of Tarifa; both seemed to confirm his accusation. But since those documents "[did] not explain all the circumstances clearly," it was impossible to determine if his complaint was well founded. The Secretary of State therefore informed Governor José Sentmanat of Cádiz that for greater speed he was sending the petitioner to him, to be treated favorably and to avoid the slow pace of Spanish justice. All was in the service of maintaining good relations between Spain and Morocco:

Because Moors cannot be treated with the formalities and delays that are usual here, and it is of the greatest importance to satisfy this man in his present appeal, both to prove Christians' good faith (especially our own) and to not endanger the peace that happily exists between this Crown and the Kingdom of Morocco, the King our master has resolved that the Moor should go to Cádiz to appear before Your Excellency. And he orders me to instruct you that once you have understood his petition and

16 “[S]e estrechó con el referido Comisionado, á fin de sacarle las intenciones, con que venia, y haviendose resistido a contextarle, dixo últimamente a el Comerciante, que jamas le diría lo que solicitaba saber, y que ya conocía, que podía haver orden de la Corte, para que no se le admitiesen aquí proposiciones, aunque fuesen ventajosas, porque en la Paz con el Emperador su Amo fue capitulo expreso el excluir el Comercio con estas Provincias, y que por tanto, no duraría mucho." Junco was grateful that the government had praised his handling of the affair: Juan Domingo del Junco to Marquis of Grimaldi, Bilbao, letters of 9, 16, and 23 May 1768, AHn, Estado, leg. 5803, Exp. 5.

17 He is also called Sidi Mahamet Bengamet Serif, Mohamat Bengamit Serif, and Mahamet Benjamimi.

18 Whose name also appears as Cerel, Cherel, Cheret, and Cherety. 
his legal case you make sure he is satisfied immediately by the debtors who owe him money, so that he will suffer no delay or annoyance for this reason. And if because those men are absent or for any other reason we can imagine they cannot be made to pay, Your Excellency shall arrange to have this Moor receive what is owed him by any means possible; afterward you have the choice of suing the actual debtors and reclaiming the amount. ${ }^{19}$

Grimaldi was asking "in the most urgent and strongest terms" on the king's behalf that "swift justice be done for him, because the honor and good faith of our nation requires it and because it helps to preserve the peace with Morocco." Besides, there was a "supposition that the Moor has just cause for complaint, as appears from his account in which one can detect a certain sincerity, which will be easier to determine here." He feared that the information he had requested from the Spanish vice consul in Tetouan would not arrive in time; but he also noted that "if I discover that the Moor is acting with malice" he would tell the vice consul, who should pass that knowledge on to the sultan of Morocco "before the Moor can tell him a false tale." He concluded that the Spanish monarch was concerned "that if the Moor has justice on his side he should receive it immediately, and even if he does not have it, no offense or injustice should be done to any vassal of his." ${ }^{20}$

Governor Sentmanat replied that he was expecting "Sidi Mahamet Bengamet Serif, who went to complain of some Spaniards who are keeping him waiting without paying him what they owe him." A few days later he reported the Moroccan's arrival in Cádiz:

19 "Como no puede tratarse a los Moros con las formalidades y dilaciones que están en estilo aqui, y es sumamente importante satisfacer a este en su actual instancia asi por acreditar la buena fe de los cristianos y especialmente la nuestra como para no dexar aventurar la paz que felizmente subsiste entre esta Corona y el Reino de Marruecos, ha resuelto el Rey nuestro señor que el moro pase a Cadiz a presentarse a V.E., y me manda encargarle que enterándose de su instancia y de la justicia que le asiste haga que inmediatamente se le satisfaga por los deudores el dinero que se le está debiendo, de suerte que no se le cause detención ni molestia con este motivo. Y si por haberse ausentado aquellos ó por otro incidente que aquí pueda precaverse no se consiguiere que ellos paguen, dispondrá V.E. que de qualquiera modo se satisfaga a este Moro lo que se le debe quedando después el arbitrio de reclamar contra los legítimos deudores y reintegrarse por esta cantidad." The Secretariat of State asks for "swift justice": draft to José Sentmanat, governor of Cádiz, Aranjuez, 17 and 19 May 1769. At the same time the vice consul in Tetouan was instructed to inform himself about the affair: Aranjuez to Jorge Patissiati, 19 May 1769, AHN, Estado, leg. 5803 .

Marquis of Grimaldi to José Sentmanat, Cádiz, 26 May 1769, AHN, Estado, leg. 5803. 
Having examined the documents he has shown me I have begun the process of the necessary steps for discovering the individuals whose creditor he is. As I have come to understand, however, none of them is a resident of this city, rather of Seville and of the Isla de León; about which I will take the appropriate measures. ${ }^{21}$

Letters from the two men must have crossed, because the governor affirmed that he was expecting the order "to have the said Moor heard in court without delay, and, the truth having been established, to have the debtor pay him. And just as His Majesty wishes to aid the vassals of the Emperor of Morocco, he does not wish to harm his own vassals in the course of his most just and upright conduct." In his search for corroborating documents he found only "one bill, which appears accurate as far as one can see, and that the debtor named Jorge Cherel is a man of ill repute." He offered as proof that the man had "disappeared, and has not yet been found in spite of all my efforts." He suspected that even if caught Cherel would not be able to pay his debt, so the desired outcome would be thwarted

because he has no funds; if he ever had them, they no longer exist today. I have kept the Moor, who seems like an honest man, informed of all this; he has a well-founded fear of his emperor's wrath, so at his request and by virtue of my obligation I will continue to pursue [the matter], guided by the information I keep gathering. ${ }^{22}$

In the meantime Benhamet kept up his pressure on the Spanish authorities. On 30 May a public scribe in Cádiz reported that the Moroccan had asked him for a document that reproduced, almost word for word, Grimaldi's letter of 17 May to the governor of Cádiz. The crucial paragraph was the one in which the governor was instructed to satisfy Benhamet because justice was usually too

21 “[C]on conocimiento de los Documentos que me ha exivido, he dado principio a la práctica de las diligencias correspondientes para el Descubrimiento de los Yndividuos contra quienes resulta ser acrehedor, no obstante que según hasta ahora he llegado a comprehender ninguno es vecino de esta ciudad, y si de la de Sevilla, y la villa de la Ysla de Leon, sobre cuio particular tomaré todas las providencias combenientes": José Sentmanat to Marquis of Grimaldi, Cádiz, 30 May 1769, AHN, Estado, leg. 5803 .

22 “...por no tener medios, pues si los tubo algún dia, ya el de hoi no existen. De todo tengo enterado al Moro quien me parece hombre de bien, i que pide con razón estar temiendo la cólera de su emperador i a petición suia, i en descargo de mi obligación la que prosigo i proseguiré guiado de la noticia que boi recogiendo": José Sentmanat to Marquis of Grimaldi, Cádiz, 6 June 1769, AHN, Estado, leg. 5803. 
slow and Spain needed to show Morocco how well it treated its subjects - all so as not to endanger "the peace that happily exists between this Crown and the Kingdom of Morocco." Even more important was the command to turn over to the Moroccan "immediately" the sum he was owed, so as to cause him "no delay or annoyance." In other words, the claim should be paid even before the case was adjudicated. ${ }^{23}$

On 13 June Grimaldi wrote to Benhamet expressing pleasure that he was now in Cádiz and that the search for Jorge Cheret and Antonio Gómez was in progress. He regretted not being able to intervene more actively in the affair. He proposed a small change in his orders to the governor: that Benhamet be given half the sum he was owed at once, with the other half to be paid after the lengthy suit against the debtors was resolved. His reasons were as follows:

You [Benhamet] surely realize that even if you were a Spaniard and a vassal of the king the matter could not be handled more urgently or with greater speed. However, so you may be convinced of the esteem with which we treat all subjects of the King of Morocco here, I wish to propose a solution that I find highly convenient for you. It is that the governor should give you half the money that those individuals owe you, with which you may return to your country without delay and avoid any reason for the king your master to be displeased. I will take care to continue the suit against those debtors and extract from them all the money they owe, so as to send you the remaining half.

He added a piece of advice that would be repeated over and over to Spanish consuls and governors, and to Moroccans who planned to go to the royal court: that they refrain from doing so and instead try to resolve their problems in Cádiz or in the city where their cases first arose:

As for coming to this court, it would be wholly fruitless because no judgment can be made here; the case against those debtors must be pursued in the city of Cádiz. And I may add that the King would not be pleased if you should make this trip again unnecessarily. ${ }^{24}$

23 Certified statement by Juan Ballés de Mérida, a public scribe in Cádiz, 6 June 1769, AHN, Estado, leg. 5803.

24 "Bien se hará Vm cargo que aun quando Vm fuere un español vasallo del Rey no se podía tomar el asunto con mas calor ni hacer mayores diligencias. Pero sin embargo, para que Vm se convenza de la estimación con que aquí se trata a todos los súbditos del Rey de Marruecos, quiero proponerle un medio que me parece mui conveniente para Vm mismo. Este es el de que ese Gobernador entregue a Vm la mitad del dinero que le deben aquellos 
Grimaldi told the governor of Cádiz that he knew of the unsuccessful pursuit of Cheret and Gómez, and sent him a copy of his letter to Benhamet in hopes that he would be encouraged "to return to his country as soon as possible." If Sentmanat were willing, he should give the man "half of his debt so that he will leave." He still ordered continuing efforts to find the debtors and force them to pay, and hoped that Benhamet would not try his luck in Madrid again:

The Moor gives me to understand that Your Excellency counseled him to return to Madrid, but I assume that he says it to stress his desire to make the journey and that you have not suggested such a notion to him. For this trip would be useless and even harmful, simply encouraging others to make the same decision and to cause us trouble. ${ }^{25}$

Benhamet told Grimaldi of his satisfaction with "all you have been so good as to favor me with," for which he would be "eternally grateful"; he had reached an "agreement to receive from the governor the sum of ten thousand reales de vellón which he will give me tomorrow, with the proper receipt." He would leave "a power of attorney with a trustworthy person" to collect the rest of what his creditors owed him, "if they, or their funds, can be located; I am aware of the earnest efforts that have been made in this city and other towns to search for those debtors, and that they will continue."26

The report on the search for Cheret and Gómez's whereabouts included statements by several witnesses. José Gutiérrez de Morón, a public scribe from the Isla de León, testified that no one had been able to tell him whether Cheret, "a foreigner," possessed "any means to speak of." He knew only that Cheret had left for Morocco leaving behind a woolen jacket, a pair of worn-out white

individuos, con la qual podrá Vm restituirse a su Pais sin dilación y evitar todo motivo de disgusto con el Rey su Amo. Y quedará a mi cuidado hacer que se continue el proceso contra dichos deudores y sacar de ellos todo el dinero que deben para embiar a Vm la mitad restante. ... Por lo que toca a venir a esta Corte seria totalmente infructuoso por que aquí no es posible tomar disposición, debiendo seguirse en esa ciudad de Cadiz el asunto contra aquellos deudores; y antes puedo añadir que al Rey no le parecería bien que Vm hiciese de nuebo este viage sin necesidad": draft to Sidi Majamet Benhamet Serif, Aranjuez, 13 June 1769, AHN, Estado, leg. 5803 .

25 "El Moro da a entender que V.E. le aconsejaba restituirse a Madrid, pero yo supongo que el lo dice por comentar su deseo de hacer este viage y que V.E. no le habrá sugerido tal idea; pues este viage seria inútil y aun perjudicial, sirviendo solo de dar pie a que otros tomen el mismo arbitrio para embarazarnos": Aranjuez to José Sentmanat, 13 June 1769, AHN, Estado, leg. 5803 .

26 Mahamet Benhamet (who signed in Arabic with a six-pointed star) to Marquis of Grimaldi, 20 June 1769, AHN, Estado, leg. 5803 . 
breeches, and a wineskin with one Andrés Pallardo, who traded in carriages. He had also heard that Cheret "was in charge of a warehouse containing some wineskins and furniture"; but a master tailor from Cádiz, Domingo Manero, declared in the name of the Franciscan Order that in 1767 Cheret had delegated him to remove all his goods from the warehouse and sell them. Manero obeyed, but could not recall what price he had obtained. On Cheret's return from Morocco he had sued Manero, but Cheret failed to appear in court in October 1768 and the case remained unresolved. Cheret had deposited with another Cádiz resident, Juan de Bonneval, a sum of money in reales, but had withdrawn it the year before and Bonneval had no fresh news of him. A business agent from El Puerto de Santa María, Antonio Hinabo, had received Cheret in his house four times before the previous May, during which visits Cheret had obtained sugar, cocoa, and indigo in loads of six to twelve arrobas apiece to ship to Granada by land. Later he had chartered a boat in Málaga and loaded a mattress, a chest, a saddle, and ten to twelve bundles of cocoa and indigo. ${ }^{27}$

Then reports began to arrive from Spanish representatives in Morocco. Jorge Patissiati, the vice consul in Tetouan, could say little about Cheret and Gómez because they were both in Larache, he himself was in Marrakesh, and his nephew Miguel Colety had gone to Cádiz. But he could state that according to Tomás Bremond, the consul general, "all these were schemes by the Moor and our Spaniards; the parties to the suit have no basis for their claims, their trading company has no financial base, and the Moor has no reputation in these kingdoms." 28 A undated, unsigned note claimed that Benhamet had formed a trading company with Cheret and Gómez on 23 August 1767, and Miguel Colety declared that the company had bought goods for a total value of thirty thousand reales. ${ }^{29}$

Governor Sentmanat considered the documents that Mahamet Benhamet had presented "fairly confusing." On interviewing him in the presence of a scribe

I found that in total the amount came to thirty-one thousand reales de vellón, although in that debt was included the capital that he had invested

27 Certificate signed by Juan Ballés de Mérida, a public scribe in Cádiz, testifying that the military and political governor, José Sentmanat y de Oms, had given him the cited statements, Cádiz, 3 June 1769. A certificate issued by José Gutiérrez de Morón, a public scribe in La Isla de León, 2 June 1769. A certificate by Lorenzo Prior, a public scribe in Cádiz, 3 June 1769, AHN, Estado, leg. 5803 .

28 Jorge Patissiati to Marquis of Grimaldi, Tetouan, 20 June 1769, AHN, Estado, leg. 5803.

29 Colety's statement of 22 June 1768, AHN, Estado, leg. 5803. 
together with Cherell and Gómez to form a profit-and-loss company, half of which would have come to fifteen thousand five hundred reales. I explained to him that one thing was the base sum that each man had invested at his own risk, and another was the goods that he had placed with the company, and therefore I reduced the sum by ten thousand reales.

Therefore, by order of the monarch, he gave Benhamet

half the cash, amounting to ten thousand five hundred, and out of this sum I agreed with him to deduct for now the five hundred reales. He pledged to accept this agreement voluntarily in the presence of the scribe. I did it because it seemed fair; if the debtors can be found we can determine with them the facts and whether the company has had losses or gains, something that neither he nor I can know.

The sum was handed over with a receipt and a letter of agreement, while the search for the debtors continued with the "greatest zeal." The governor denied to Grimaldi ever having counseled the Moroccan to present himself at court:

Your Excellency may be sure that that was just the opposite of what I advised him; I saw it was impossible and judged how long he would wait for payment, [so I suggested] that he return home and leave in this city a reliable person with authority to pursue the case and collect what was available, assuming that the absent debtors could be located.

Benhamet, he went on, "is resolved to return to his country, but knowing that I will continue my pursuit of his debtors he is leaving a representative for whatever may be needed." Sentmanat begged that the Royal Treasury reimburse him for the ten thousand reales he had given the Moroccan, and that the vice consul in Tetouan be kept informed of all developments. ${ }^{30}$ Grimaldi

30 "[E]ncontré que en globo, importaba la dicha cuenta treinta y un mil reales de vellón bien que en esa deuda yncluie el capital que el puso como los demás Cherell y Gomez formada Compañia a perdida o ganancia cuia mitad ubiera importado quince mil y quinientos reales. Ysele presente que una cosa hera el fondo que cada uno avia puesto a ventura y riesgo y otra cosa los generos que el avia dado a fiar para Compañía y que asi le revajava diez mil reales. ... la mitad del liquido que importaba diez mil y quinientos, y de esta porción, ajusté con él revajar por ahora los quinientos reales a cuio convenio adirio en presencia del referido escribano voluntariamente, lo hize pareciéndome equitativo por si pudiesen ser avidos los deudores averiguando con ellos la verdad, y si en la Comp ${ }^{\mathrm{a}}$ ha auido perdidas ó ganancias, lo que ni el, ni yo podemos sauer. ... [P] uede V.E. estar cierto 
told the Secretary of the Treasury, Miguel de Muzquiz, the whole story of Benhamet and asked him to send the ten thousand reales to the governor of Cádiz:

\begin{abstract}
After the Moor named Sidi Mahamet Bengamet Serif came to me in Aranjuez complaining of some Spaniards who had formed a trading company with him in Tetouan, and then had fled without paying him what he was owed, the king had me send him to Cádiz with a letter for Don José Sentmanat, governor of that port. In it [Sentmanat] was advised to take notice of the matter at once and arrange for the Moor to have his money restored promptly, to avoid justifiable complaints by the king of Morocco, since we know that those Moors obey principles very different from our own and usually seize the recompense they think they are owed on their own initiative. ... By virtue of this the king was pleased to order that for the moment the governor of Cádiz should give the Moor ten thousand reales de vellón (which is half of what is due to him), to make it possible for him to return to his country and so that he cannot tell the king of Morocco that he was denied justice in Spain. ${ }^{31}$
\end{abstract}

Shortly after Benhamet was paid his ten thousand reales the entire scheme was exposed as a fraud. The Secretariat of State received documents of Jorge Cheret's that described five receipts from Benhamet then in his possession:

de que a sido tan al contrario como que desde luego le aconsejé viendo la imposibilidad, y lo que juzgaba se dilataría el cobre que se retirase a su domicilio, y dejase en esta ciudad, un yndividuo de su satisfacción con Poder bastante para seguir las diligencias, y poner cobro a lo que se encontrare siempre, que pudiesen ser auidos los deudores ausentes." The governor was repaid the ten thousand reales in July of that year: José Sentmanat to Marquis of Grimaldi, Cádiz, 27 June and 25 July 1769. Certificate of payment by Juan Ballés de Mérida, public scribe in Cádiz, 21 June 1769, AHN, Estado, leg. 5803.

31 "[Tras] habérseme presentado en Aranjuez el Moro llamado Sidi Mahamet Bengamet Serif quejándose de algunos españoles que hicieron con el compañía de comercio en Tetuan y después se huyeron de allí sin pagarles lo que le correspondía, me mandó el Rey embiarle a Cadiz con carta para D. Joseph Sentmanat Gobernador de dicha Plaza en que se le prevenía tomase inmediatamente noticia del asunto y dispusiese que el expresado Moro recuperase su dinero desde luego: para evitar justas quejas del Rey de Marruecos, quando sabemos que aquellos Moros se manejan por principios mui diversos de los nuestros y suelen tomarse por si mismos la satisfacción que creen se les debe. ... En virtud de ello se sirvió el rey mandar que por el pronto entregase el Gobernador de Cadiz al expresado Moro diez mil reales vellon (que es la mitad de su crédito) para ponerle en el estado de restituirse a su Pais y que no pudiese decir al Rey de Marruecos se le negaba la justicia en España": Grimaldi to Miguel de Muzquiz, 4 July 1769, AHN, Estado, leg. 5803. 
The first two, from 25 August, for one hundred fifty reales de vellón apiece; another of 20 September for three hundred, signed by me and Don Antonio Gómez; another of the same for fifteen pesos fuertes containing two more statements of profit, signed by Captain Manuel Díaz on 30 September; and the last receipt of the 27th of the same [month] for two pesos fuertes, signed by Gabriel Carreras. All are from the past year 1767. By virtue of the power of attorney that Benjamimi gave me to settle accounts with Don Antonio Gómez in Seville, once those [accounts] were settled and the company's funds distributed (as the three of us did on 23 August [17]67), the value of the receipts was reduced. And if it should not be so, Benhamimi required me to present them for a second time so that he could keep them.

One of the receipts stated:

I, Sidi Hagmet Benjamimi, allow and give absolute power to Don Jorge Cherel to settle the accounts of the company that he, Don Antonio Gómez, and I formed in the port of Larache on 23 August of last year, 1767. And once that is done he may receive any balance in my favor, in accordance with the usual agreements. And in case Don Antonio Gómez, who resides in Seville, and with whom the account should be settled, does not consent as he ought, the said Don Jorge Cherel may bring him to court and oblige him to show everything he was given in Larache. This power of attorney may be delegated to such person as he may choose, who may act and sell movable property and real estate belonging to the debtor, for which I have given Don Jorge Cherel all the papers that may pertain to this matter.

It is clear from the documents, all contained in one folder, that the Moroccan's claim was fraudulent. Tomás Bremond, the Spanish consul in Morocco, was instructed to tell the sultan about the affair and reveal "the dishonesty of the Moor" who had managed, "through the generosity we have shown him here as a vassal of that prince, to be paid for the moment half of what he was supposedly owed by presenting a single piece of paper." The sultan should be asked to "force the Moor to pay back what he owes and has obtained unfairly in Spain."32

32 “...los dos primeros de 25 de Agosto, de ciento y cinquenta reales de vellón cada uno; otro de 20 de septiembre de trescientos, firmado este por mi, y D. Antonio Gomez; otro ydem de quinze pesos fuertes, expresando en el dos dichos mas de ganancia, firmado, por el 
A month later, news from Tetouan revealed how great a trick had been played on the Secretariat of State. Miguel Colety, Patissiati's nephew, had returned to the city after recovering from an illness and questioned the actions of Grimaldi and Sentmanat: "what that Moor alleged was invented and false, and in fact he is the one who owes Don Jorge Cheret the sum that has been mentioned." There could now be no doubt in the case:

In June of last year Don Jorge Cherel arrived here pleading a case against the Moor Benjamimi, to make him restore the sum of fifteen thousand reales de vellón named in a bill he had given him against Don Esteban Joseph Rey, a merchant in the port of Larache, which he [Benjamimi] had cashed while Cherel was in Morocco. Therefore I called the Moor into court and explained the suit against him in the presence of several Moors of the city, including Samar, the administrator of the port of Larache and a protector of Benjamimi's. At first he denied the debt absolutely, but when we showed him a document signed in his own hand and threatened to put him in irons while we informed the Emperor (who had had him in irons shortly before, for other schemes), he begged me to settle the matter so that it would go no further.

The vice consul, "seeing how impossible it would be to collect," had agreed with Cheret to make copies that he himself would verify and, "in case more things occur with time," he would also copy the available documents from the

Patron Manuel Diaz en 30 de septiembre, y el restante ultimo recibo de 27 del mismo, de dos pesos fuertes, firmado por Gabriel Carreras todos del año pasado 1767; los que en virtud del Poder que dicho Benjamimi, me tiene otorgado para tomar cuentas a dn. Antonio Gomez, en Sevilla, las que, ajustadas, que sean, y repartidos los caudales de la Compañía, que con fecha de 23 de Agosto de 67, se hizo entre los tres, se rebaje el Ymporte de dichos recibos; y siempre, que no suceda assi, me obligo a entregarlos segunda vez, al expresado Benjamimi, y para su resguardo. ... Yo Sidi Hagmet Benjamimi, otorgo, y doy poder absoluto a don Jorge Cherel para que ajuste las Cuentas de la Compañía que entre el, Dn. Antonio Gomez, y yo, hemos hecho en el Puerto de Larache en 23 de Agosto del año pasado de 1767; y después de executado, lo que resultare a mi favor lo reciba en la conformidad que se acostumbra con los Ynstrumentos necesarios; y siempre que $\mathrm{dn}$. Antonio Gomez, que reside en Sevilla, y es, a quien se le debe tomar el ajuste de cuentas, no quisiere concurrir como es devido, queda el dicho dn. Jorge Cherel ponerlo por justicia, obligándolo a manifestar todo lo que se le ha entregado en dicho Larache; pudiendo sobstituir este Poder a la Persona que el mismo eligiese para que, este, exequte, y venda muebles, bienes, y raizes del Deudor, para cuio efecto, he entregado a dicho Dn. Jorge Cherel quantos papeles puedan pertenecer al asumpto": Document signed by Cherel in Tetouan, 22 June 1768; another signed in Latin letters by Benhamet, also in Tetouan, 12 June 1768, AHN, Estado, leg. 5803. 
business dealings among the three partners. Those proved that the company had been formed only between Benhamet and Gómez and that Cheret had been involved in just "a few minor matters." Benhamet's documents consisted of some receipts and a power of attorney in Arabic

prepared by the adules or scribes of their religion, in which Benjamimi affirmed that he could claim nothing from [Cheret]; and that if he should receive some of the fifteen thousand reales from Gómez, there was no further place to appeal to for satisfaction.

With those copied and witnessed documents Cheret left for Cádiz and then Seville in search of Antonio Gómez, but was unable to find either him or Benhamet, who

left here a few days ago because he was not allowed to embark for Europe from any port here [in Morocco]; finally he traveled by land to Algiers, from which he sailed to Port Mahón and then to Gibraltar. ${ }^{33}$

Bremond wrote of Benhamet's utter untrustworthiness, since he also had problems in his native land. He had informed the governor of Cádiz about

the deception carried out by the Moor Mahomet Benjamimi in relation to his complaint against Don Jorge Cherell and Don Antonio Gómez,

"En junio del año pasado se presentó en esta Don Jorge Cherel pidiendo justicia contra el Moro Benjamimi, a fin que le satisfaciese la cantidad de quinze mil reales de vellón, procedentes de una Letra que le havia entregado contra Don Esteban Joseph Rey, comerciante en el Puerto de Larache, y que cobró durante la estada de Cherel en Marruecos; por lo que, hize llamar a Juicio a dicho Moro, y haciéndole cargo de lo que se le pedia, en presencia de varios Moros de la Ciudad, y entre ellos Samar, Administrador del Puerto de Larache, y Protector del expresado Benjamimi; al principio negó absolutamente la deuda pero exponiéndole Ynstrumento firmado por su mano, y con amenazas de ponerlo en cadenas, hasta dar aviso al Emperador (quien, poco antes lo tenia assi, por otras picardías) me pidió mirase componerlo para que no pasase adelante. ... hecho por los Adules, ó escribanos de su Ley, en el que, firmaba Benjamimi, no poder pretender de este cosa alguna, y si que quanto pudiese cobrar del expresado Gomez, lo percibiese, á cuenta de los quinze mil reales, pues que no havia otro arbitrio, de donde poder satisfacerlo. ... [P]asados algunos días se ausentó de aquí, por no permitirle se embarcase en ninguno de los Puertos para Europa, y solo últimamente, que por tierra marchó a Argel, de donde pasó a Puerto Mahon y luego a la Plaza de Gibraltar": Jorge Patissiati to Marquis of Grimaldi, Tetouan, 20 July 1769 and 15 September 1769 . Miguel Colety to Marquis of Grimaldi, Tetouan, 20 July 1769, AHN, Estado, leg. 5803 . 
who, he wickedly claimed, owed him the sum of twenty thousand reales, half of which was issued to him by the Royal Treasury. The governor of Cádiz told me of it on 23 July and on 24 July I replied about the Moor's dishonesty and how I was impeding his return to this country from which his crimes had expelled him, on the remote chance that he should return here.

He promised to inform the sultan of the "absurd" behavior of his subject "Mahomet Benjamimi, and to convince him of the generosity with which we restored half of his debt, out of respect because he was [the sultan's] vassal." ${ }^{34}$

Later it was learned that Cheret was in prison in Granada. In early October Grimaldi wrote to the governor of Cádiz enclosing the king's order to the president of Granada's Royal Chancellery to release Cheret and return his embargoed goods. As a result Sentmanat suspended the legal pursuit of Cheret and Gómez. ${ }^{35}$ Almost three weeks later Grimaldi wrote to the president of the Chancellery once again, noting that Cheret (whom he called "Pedro Cerel") was still a prisoner and his goods had not yet been released, adding, "it is now established that all the statements and complaints by the Moor Mohamet Bengamimi were false, for the [the two men] whom he calles his debtors were actually his creditors"; he repeated that the king wanted Cheret freed at once and his property restored. ${ }^{36}$ Writing again on the same day he said he had received via the French ambassador a report from Cheret, whom he considered clearly innocent based on information from the consul general in Larache and the vice consul in Tetouan. In the king's opinion the justice system had exceeded its authority with Cheret, who was now seventy years old and plagued with "many ailments." The Moroccan sultan had been urged to "punish that Moor severely and force him to pay the sums he ows to Spanish vassals." ${ }^{37}$

34 “...el engaño usado por el Moro Mahomet Benjamimi, perteneciente a la queja que dio contra dn. Jorge Cherell y dn. Antonio Gomez, de quienes supuso siniestramente deudas a su favor hasta en cantidad de veinte mil reales, cuya mitad se le satisfizo del Real Erario, de que en 23 de Julio me dio parte el Governador de Cadiz, y en 24 de Julio le contesté la falacia de dicho Moro, y quanto yo dificultava viniese á estas Tierras, donde sus delitos le ahuyentaban, y assí en caso remoto buelva á ellas": Tomás Bremond to Marquis of Grimaldi, Larache, 7 September 1769, AHN, Estado, leg. 5803.

35 José Sentmanat to Marquis of Grimaldi, 2 October 1769, A HN, Estado, leg. 5803.

36 San Lorenzo [El Escorial] to Francisco José Velasco, president of the Chancellery of Granada, 19 October 1769. He was relying on the reports of Tomás Bremond: AHN, Estado, leg. 5803 .

37 San Lorenzo to the president of the Chancellery of Granada, 19 October 1769, AHN, Estado, leg. 5803 . 
Cheret, now residing in Granada, certified having received the sums and documents that had been seized from him:

I acknowledge having received to my entire satisfaction from the magistrate, scribe, and recorders of this city 620 pesos sencillos; a deed for five thousand four hundred reales de vellón; a paper for 7,239 reales de vellón; another for seven hundred reales, and one more for 180 . All these are credits in my favor and against several other persons. And likewise all the remaining papers, letters, dispatches, and documents that were taken from me at the time of my arrest have been given to me in total and to my satisfaction. ${ }^{38}$

But Cheret also wrote a letter to Grimaldi to be forwarded to the king, decrying "the ill usage and abuse committed by the justice system in this kingdom to the French nation and to me in particular." In defective Spanish he explained that he was the creditor of both Benhamet and Gómez:

It is true that I formed a company with a Moor and a Sevillian, and that Moor encouraged the Marquis of Grimaldi to abuse me and in fact they have done so when there was no reason for it nor have they given any reason or occasion for it. The Moor invested ten thousand reales in the company, the Sevillian another ten thousand, and I another ten thousand, making thirty thousand that the Moor kept in order to use them, and he did use them: he gave them to the Sevillian so that he could go to Seville to sell. And I have nothing from the company except the contract signed by the Moor and the Sevillian. I also have a paper signed by the Moor stating that he owes me eleven thousand reales, with the condition that at twenty days from that date he had to come to Cádiz to pay me, and also another paper signed by that Moor for twenty-one thousand reales, but he did not come or appear for more than a year. Then I crossed to Barbary in search of the Moor and found him in Tetouan; I presented

38 " [C]onfieso haver resevido a toda mi satisfacción de la Justicia, Escribano y depositarios de esta dicha Ciudad, Seiscientos veinte pesos censilllos; una escritura de cinco mil y quatrocientos reales vellón, papel de siete mil y doscientos treinta nueve reales vellon otro de settecientos reales y otro de ziento y ochenta, cuios papeles son créditos en mi favor y contra varias personas, $\mathrm{Y}$ asi mismo todos los demás papeles, cartas, despachos y documentos, que al tiempo de mi arresto se me habían sequestrado, y de darme por entregado íntegramente, a mi satisfacción": statement by Jorge Cherel, Granada, 26 October 1769, AHN, Estado, leg. 5803. 
my papers to the vice consul of Spain asking for justice, and the consul agreed that the Moor must give me an accounting of the goods that he had given to the Sevillian. He also gave me an absolute power of attorney to solicit the Sevillian and demand from him the sum that the Moor owes me. [Because of] my health and my business affairs I have been unable to go to Seville to confront the Sevillian. The Marquis of Grimaldi wrote to the governor of Cádiz and that governor has sent a case against me to the court in Granada to have them accuse me, and they have done so without taking any statements or declarations.

He had been arrested and sentenced to prison "with a guard always present so that I could neither speak nor write," and stripped of 620 pesos fuertes and deeds for 5,500 reales, seven thousand reales, seven hundred reales, and 180 reales respectively:

... and a variety of other bills for what I am owed in other places that were issued in Granada, but they took away the correspondence from my business. They have trampled on the treaties of peace and the privileges that His Majesty concedes to the French nation; they have taken away my documents and I am the only person in Spain who possesses them. They have also disregarded the passports given me by Don Juan de Villalba, general of El Puerto de Santa María. They have abused my seventy years while I am not in good health - my legs are swollen and covered with boils that ooze fluid continually - without any care for charity. It is no surprise, because the scribe is my mortal enemy: he went to take a statement from a man whom I have sued, so that I, knowing that the scribe had not fulfilled his responsibility, denounced him, and now he is taking vengeance with his actions. I beg you to give His Majesty this report so that he will have the goodness to order my funds returned to me and have me released; also that he command my honor and respect to be restored, for I have given no motive to be abused. As another favor I beg of His Majesty's charity (may God preserve him for many years!) to protect from Spanish powers the Moor's papers as well as everything else they have taken from me. The sum they took from me is more than five thousand five hundred pesos, and I beg you not to allow the justice system to consume them. In truth, my "crime" is that the justice system wants to keep my money and force me into poverty.

Cheret was convinced that if justice were not done, at his age and in his state of health "I will have to beg for alms." As a final plea he claimed that "By the law of 
the kingdom no one can be imprisoned at the age of seventy, and I am seventy and have committed no crime that justifies my imprisonment."39

A royal scribe in Granada, Fernando Pérez Lozano, verified that Cheret had been freed and given 3,197 pesos fuertes by order of the Marquis of Grimaldi. ${ }^{40}$ The president of the Granada Chancellery hastened to deny that Cheret

39 “[E]s berda que tengo echa, Compañía con un Moro y un Sebillano y el dicho Moro a empeñao al Señor Marques de Grimaldi para que me atropelle con efecto me an atropellado sin aber motibo para ello ni aber dado motibo ni lugar para ello y tiene puesto el dicho Moro en la Compañía diez mil reales, el Sebillano otros diez mil y llo otros diez mil que son treinta mil que el Moro se quedo con el para emplear y lo empleo le entrego al Sebillano para que fuera a Sebilla a vender y llo no tengo nada de la Compañía, Solamente tengo el papel de la contrata firmada del Moro y del Sebillano y también tengo llo un papel firmado del Moro que me debe once mil reales, Con condision que a los veinte días de la fecha abia de benir a Cadiz a pagarme y otro papel también, firmado del dicho Moro de beinti un mil reales, y no bino ni pareció en mas de un año y entoses yo, pase a la Berberia en búsqueda, del dicho Moro y llo le encontré en Tetuan, y lo presente mis papeles al Señor SotoConsul, de España para que me ysiera Gustisia, y lo que saco el Consul de acuerdo que, el dicho Moro me entregase la Carta Cuenta, de los Generos que abia el Moro entregado al Sebillano y que me dio un poder al soluto para tomar Cuenta del dicho Sebillano y aplicarle llo la que llo cobrase a la cuenta del que me debe el Moro mi salud y los Negocios mios no me an dado lugar a pasar a Sebilla a tomar Cuentas al dicho Sebillano y Señor Marques de Grimaldi a mandado una carta al Señor Gobernador del Cadiz y el dicho Señor Gobernador a despedido una requisitoria contra mi a la Gusticia de Granada para que me atropellaran Como asi lo an ejecutado sin tomar ynformes ni declaraciones. ... y mas diferentes papeles que me deben en otras tierras que son dilatadas de Granada mas me an quitado las Cartas de la Correspondensia de mi Comersio y an atropellado los tratados de pas y los pribilegios que tiene consedida la Magesta a la Nasion francesa y también me han quitado los dichos tratados que no ai mas que llo en España que los tenga y también an atropellado los pasaportes qe me [ha] dado el Señor D. Juan de Billarba General del Puerto de Santa Maria y también an atropelado la edad de setenta años y que llo no tengo salud que tengo las piernas ynchadas y con llagas que echan Materias continuamente por ellas sin mirad la Caridad no ai qe almirarse por que el escribano es amigo mortal Mio por el motibo que fue a tomar una declarasion a un hombre con quien tengo llo un pleito y llo conosiendo que el dicho Escribano no abia cumplido con su obligacion lo rrecurse y aora, a tenio la ocasión de tomar la bengansa como asi lo esta egecutando y llo suplico a vuestra Grandesa que se digne en Carida de representar a la Magesta este Memorial para que la Magesta me aga la Carida, de mandarme que, me buelban mi Caudal, y mandar ponerme en liberta como también mandar que se me buelba mi honor Respeto que no e dado lugar a que se me atropellase en semegante favor que llo suplico en Caridad de la Magestad a quien Ds.ge.ms.as., para el amparo de la Gerarquia de España los papeles del Moro como todo los demás que me an quitado y los dineros que me an quitado pasa de Sinco mil y quinientos pesos y suplico a buestra Grandesa de no consentir qe la Gustisia se los coma que el delito que llo tengo en sustasia es que la Gustisia pretende quedarse y aserme gastar mi pobresa": unsigned, undated petiton by Jorge Cheret to Marquis of Grimaldi, AHN, Estado, leg. 5803 . 
had been badly treated: "everything stated in his report about poor treatment and severe imprisonment is without foundation, as I have determined; and the subject himself did not dare to contradict me in the presence of the judge and the scribe in the case, although he was fairly free in expressing himself." 41

Surprisingly, Sidi Mohamet Benhamet reappeared in Spain in October 1770. In a new petition he alluded to another he had written "on 5 June of last year 1769," which had made a claim against Cheret and Gómez "for the legitimate sum of thirty-four thousand reales that they owed me." He admitted that the governor of Cádiz, by order of the Secretary of State, had paid him half of this debt and urged him to return to Morocco, "since he would oversee the process until he had obtained all the money from them, when he would send me the rest. And in fact I was given ten thousand reales de vellón."

After returning home, he had come back to Spain for the purpose of converting to Christianity:

Now returned to Spain with the sole objective of embracing the Christian religion, to which I find myself spiritually attracted, with a petition on this date I inform His Majesty (may God preserve him) that I have heard that Cheret, a rash man who does not keep his agreements, has suits pending in every port in Andalusia, especially in Granada, Cádiz, Sanlúcar, and Gibraltar, like the suit I have brought against him. One of my relatives (who are great enemies of mine because I wish to become Christian) has informed against me to the consul, pretending that I am the debtor, or that things are otherwise than he supposed. But among the statements pending before the governor of Cádiz there are papers signed by Cheret and by the consul himself that attest that I am owed the aforementioned thirty-four thousand reales. I am telling Your Excellency this to justify my conduct and explain the calumny of the consul, not to recover that sum, something I do not expect; because I have abandoned greater things - my homeland, estate, parents, brothers, and sisters - simply to march under the banners of Jesus Christ and receive the most holy water of baptism, the only purpose of my coming to Spain, without any other object or temporal cause.

We hear no more of the story of Benhamet, who insisted that he was the creditor of Cheret and Gómez (whom he does not mention here, and about whom

41 Fernando Josçe de Velasco, president of the Chancellery of Granada, Granada, 27 October 1789, AHN, Estado, leg. 5803 . 
no one ever learned anything). Benhamet must have been fairly well informed about how business was conducted in the Peninsula. He probably went to Spain in flight from enemies in Morocco, among them his own family; that might explain why he kept presenting himself, against all the evidence, as the victim of his former partners:

I beseech Your Excellency to look kindly on this respectful request for satisfaction and keep it in mind, so that I will not be prejudiced by any false claims that have been imputed to me through the consul at the request of Don Jorge Cheret, who is in very good standing with him, and of my relations, who abhor me utterly because, abandoning their religion, I embrace the Catholic one, in which I shall be reborn through baptism. ${ }^{42}$

Unless new sources prove otherwise, it seems that Moroccans had limited opportunities to engage in commerce in Spain during this period. Perhaps they felt little interest in an activity that was so thoroughly controlled by European merchants; they enjoyed no competitive advantage if they tried to enter directly into Spanish-Moroccan trade. They would have to await a more propitious moment at which information, experience, capital, and initiative would combine to help them cross the Strait. The windows of opportunity thus opened surely helped the sorts of adventurers mentioned above to make their profits

42 "[V]uelto a España con solo el objeto de abrazar la Religion Christiana, á que sobrenaturalmente me hallo inspirado, como con Memorial de este dia lo hago presente a S.M. (que Dios guarde) he sabido que por sugestiones de Cheret, hombre intrépido, y que por no cumplir sus tratos tiene Pleytos pendientes en todos los Puertos de Andalucia, y especialmente en Granada, Cadiz, SanLucar y Gibraltar, á semejanza del que yo le he puesto; y asi mismo de mis Parientes, Capitales enemigos mios porque quiero ser Christiano, ha informado contra mi el Consul en fingir que soy yo el Deudor, ó en otra cosa de las que haya supuesto; pues en los Autos pendientes en el Gobernador de Cadiz existen los Papeles firmados por Cheret, y por el mismo Consul, en que se justifica, que soy Acreedor de los expresados 34 mil reales. Que esto solo lo hago presente á V.E. por dar satisfacción de mi conducta, y sincerarme de la calumnia del Consul; y no por cobrar aquella cantidad, que no pienso; pues dexo otras mayores, mi Patria, Hacienda, Padres, y Hermanos, por solo militar baxo las Vanderas de JesuChristo, y recibir el Agua sacrosanta del Bautismo, único fin de mi venida á España, sin otro objeto, ni causa temporal alguna. ... A V.E. suplico se sirva admitir con benignidad esta reverente satisfacción, y tener la presente, á fin de que no se me perjudique qualesquier imposturas de las que por el Consul se me hubieren imputado, á solicitud de dn. Jorge Cheret, que con él tiene grande valimiento, y de mis Parientes, que del todo me han aborrecido, porque dexando su Ley, abraxo la Catholica, en que he de ser regenerado y con el Bautismo": petition by Sidi Mohamet Benhamet Charif "of the city of Tetouan, Empire of Morocco," who again signs in Arabic with a sixpointed star. Dated in San Lorenzo de El Escorial, 1o October 1770, AHN, Estado, leg. 5803. 
in any way they could, and can also explain why they figure so largely in contemporary documents.

\subsection{Consolidation of a Moroccan Mercantile Colony (1780-1799)}

The war of 1779-1783 between Spain and England, which coincided with the American Revolution, produced significant changes in Hispano-Moroccan trade relations. Ships sailing between the two countries no longer flew the British flag, and even the French and Spanish ones were seen more rarely as the Royal Navy patrolled the Strait and its base in Gibraltar. Yet the war made trade across the Mediterranean more essential than ever, as fewer vessels carrying wheat from the Atlantic and the Mediterranean were able to reach Spanish ports. Spain responded by relegating its war of $1774-1775$ to the past and pursuing closer relations with the Moroccan sultan. The result was the Convenio or Agreement of 1780, signed in Aranjuez by Ibn Utman and the Count of Floridablanca, which ratified the earlier Treaty of 1767. It marked the reestablishment of peaceful relations after the 17741775 war, crucial to ensuring the supply of wheat imported from Morocco.

The Agreement revealed Moroccan merchants' increasing interest in conducting business on Spanish soil, which was evident in the preamble: it was made "for the mutual benefit of their vassals and the advantages of commerce between them." ${ }^{\prime 3}$ Its first two articles spoke of the warm reception that Spaniards would find in Morocco: they would have to pay the usual duties, but those would be "fixed and guaranteed without any addition." Further, "The king of Spain shall do the same and no more for Moroccan merchants in his domains." Although North African commercial activity was limited to the ports of Cádiz, Málaga, Alicante, and Barcelona, the possibility of expansion to others was left open:

Vassals of the king of Morocco may come to trade in the ports of Alicante, Málaga, Barcelona, and Cádiz, and in those and the others in these kingdoms they shall be well treated and well received and will be provided with what they need of victuals and the repair of their ships when they pay for their expenses and the items they purchase. [Article 3$]^{44}$

43 Cantillo, Tratados, 567.

44 "[L]os vasallos del rey de Marruecos podrán venir a comerciar á los puertos de Alicante, Málaga, Barcelona y Cadiz, y así en ellos como en los demás de estos reinos serán bien tratados y bien recibidos, y se les franqueará lo que necesiten en víveres, y para reparar 
The Agreement reaffirmed that the lives and property of Spaniards in Morocco would be protected: they would not be required to house or support anyone, their rental agreements would be respected absolutely, and they could build houses if they wished (Articles 7 and 8). In the same spirit of reciprocity as in the Treaty of 1767 , these tenets would hold true for Moroccans in Spain (addendum to Article 2). The norms that regulated freedom of movement and of trade for North Africans on Spanish soil were broadened. ${ }^{45}$

Still, the most important feature of the 1780 Agreement resided in two earlier articles that show how eagerly Moroccan merchants sought to participate in trade between the two countries. They were given the opportunity to replace, at least in part, the Spanish ships that had to endure the Royal Navy's blockade, and to make up for the absence of the English merchant fleet since the start of the war:

Our vassals the merchants of Tetouan, who used to trade in hides and other items in the port of Gibraltar, observed that English ships took these hides and items from Gibraltar to Barcelona, earning much profit from them. And since that trade with Gibraltar has ceased they have asked us [for permission] to trade in Barcelona, and to seek partners with whom to form companies for that trade, so as to have a fair share of this merchandise. When the same ships mentioned above unload their cargoes in Tetouan the tradesmen can load them with goods from our country and send them to Barcelona, where they will take on silk and other items. We give our royal word that these businessmen can be secure in their interests.

Spain responded that the Moroccans "may proceed freely to Barcelona in order to trade, and there pay the duties that have been fixed and established." Merchants from Fez were equally interested in trading in Cádiz:

The merchants of Fez, who normally trade in the East, carry silver coin for their business and exchange it for gold, because in those parts they lose by paying in silver. Therefore they have asked us to allow them to send two representatives a year to Cádiz to exchange silver for gold, and to buy cochineal at the current price. For that product is desirable and

sus navíos pagando los gastos que hicieren y efectos que compraren": Cantillo, Tratados, $5^{6} 5^{-68 .}$

Cantillo, Tratados, 565-68. 
sells very well in Fez, and one who sells it can receive Spanish money if he wishes, otherwise he can be given hides or wax in exchange.

Once more the Spaniards gave a favorable reply:

These merchants may come to Cádiz to buy cochineal and other Spanish products at current prices. As for exchanging silver for gold, so long as the latter metal is plentiful (because it is very scarce just now), it will be allowed if they pay for its extraction, and [pay] on other goods the same duty that the most favored nation pays in Spain; and we will accept Spanish coin and other products that they bring. ${ }^{46}$

These two articles provide abundant proof that merchants from Tetouan and Fez sought to participate actively in commercial activity with Spain. Prior experience of many Moroccan tradesmen in that country must have helped them envision the possibilities for profit offered by Spanish ports and cities.

Cádiz, because of its proximity and its importance in the network of Spanish ports, was especially attractive to Moroccans. Most of these, so far as we know, were representatives of the Moroccan government sent to conduct different kinds of business.

$46 \quad$ "Los comerciantes de Tetuán, nuestros vasallos, que antes acostumbraban comerciar en la plaza de Gibraltar con pieles y otros efectos, observaron que las embarcaciones inglesas llevaban de Gibraltar estas pieles y efectos a Barcelona y que con ellos hacían muchas ganancias; y como ha cesado dicho comercio de Gibraltar nos pidieron de comerciar en Barcelona, y buscar compañeros con los cuales hagan compañías en dicho comercio para tener una misma correspondencia en estas mercaderías, y los mismos navios arriba dichos en descargando en Tetuan las provisiones, las cargaran los mercaderes de efectos del país, y las remitirán a Barcelona, de donde cargaran seda y otros efectos. Estos negociantes de vuestra Majestad podrán estar seguros en sus intereses bajo nuestra real palabra. ... [L]os comerciantes de Fez, que por lo regular comercian en Oriente, llevan consigo moneda de plata para su comercio, cambiándola por oro, porque en aquellas partes pierden con la plata. Con este motivo nos han suplicado les permitamos que envíen dos comerciantes al año á Cadiz para cambiar la plata por oro, y que puedan comprar la grana cochinilla según el precio corriente; porque éste género se desea y tiene en Fez mucha salida, de suerte que el que vende dicha grana si quiere recibir por ella la moneda española se le dará, y si quiere en cambio pieles ó cera también se le dará. ... [P]uedan estos comerciantes venir á Cadiz para comprar la grana y demás géneros españoles al precio corriente. Y en cuanto al cambio de la plata por oro, siempre que abunde este metal, porque ahora es muy escaso, se permitirá pagando por su estraccion y por la de los demás géneros los derechos que paga en España la nación mas favorecida; y se admitirán la moneda española y efectos que trajesen": Cantillo, Tratados, 565-68. 
In late 1781 the sultan decided to send a merchant from Tetouan to Cádiz to buy cochineal worth thirty thousand pesos fuertes, though in his first journey the man brought only fifteen thousand. The Spanish consul in Tangier was glad not to have any responsibility for the mission, because

[errands] of this nature can be very harmful when their happy outcome depends on the will of two or three Moors who vie with each other for the sovereign's favor. If they are not well bribed they give an ill report of the quality [of the merchandise] so that it will not be accepted. ${ }^{47}$

The sultan assigned a Moroccan resident in Cádiz to receive a transfer of fourteen thousand duros or pesos fuertes, sent in April 1783 for making various purchases: "[the sum] should be given to the Moor who I am informed is the one to receive it."48 In June of that year the Spanish consul in Tangier was instructed to allow "prompt passage to Cádiz for a Moor who is sent to buy ships' timbers. ... A Moor will cross from this [port] to Cádiz to charter a ship for Larache, where he will load wood for making gun carriages; he will proceed to Gibraltar, where one hundred of them will be built."49

In April 1784 some "Moors" were sent to Cádiz to make purchases and oversee "the manufacture of tent awnings, glass windows, and a litter for this sovereign." ${ }^{50}$ In 1786 the sultan's representative for foreign affairs, a Genoese named Francesco Chiape, told Floridablanca that by the sultan's orders the first ship to sail from Tangier to Cádiz must carry "four Moors and some money that the sovereign is sending to Smyrna; he has entrusted this mission to the French consul in Rabat, who has transferred it to his counterpart in Cádiz. He will ensure that those Moors and the money will reach Smyrna as soon as possible."51

In 1793 a captain from Rabat came to Cádiz in command of a tartane loaded with wheat; he bought some foodstuffs and requested a passport so that he

47 “...[L] as de esta naturaleza suelen ser muy perjudiciales quando su felicidad esta pendiente de la voluntad de dos o tres Moros que el Soberano diputa para que la reconozcan, quienes en no dándoles una buena gratificación informan siniestramente de su calidad para que no se reciba." The consul added that the former Dutch consul, among others, had been manipulated in this way: J.M. González Salmón to Count Floridablanca, Tangier, 19 and 24 November 1781, AHN, Estado, leg. 4314.

48 J.M. González Salmón, Spanish consul in Tangier, to Count Floridablanca, Secretary of State: 4 April 1783, AHN, Estado, leg. 4317.

49 Two letters from J.M. González Salmón to Count Floridablanca, Tangier, 4June 1783, A HN, Estado, leg. 4317.

50 J.M. González Salmón to Count Floridablanca, 14 April 1784, AHN, Estado, leg. 4317.

51 J.M. González Salmón to Count Floridablanca, Darbeyda, 27 January 1786. 
could not be detained by Spanish warships. The Spanish consul, who was in Cádiz at the time, gave it to him "to the captain's great satisfaction." ${ }^{2}$

Spain clearly tried to make sure that Moroccans were well treated on Spanish soil. In 1793 the consul wrote to the sultan's brother, Muley Absalem, assuring him that they would always be well received in Cádiz: "We will always show the same consideration and friendship that Moors now living in Cádiz, who have come from Tetouan on business, already receive."53

Spain, however, always tried to privilege the participation of its own fleet and merchants in direct trade between the two countries. When in 1782 several merchants from Tangier wished to accompany a shipment of oxen to Tarifa, the Secretariat of State instructed the Spanish consul in Tangier to facilitate cattle imports "and prevent, politely, the Moors from crossing to Tarifa." 54 But Moroccan merchants continued to press: in June 1784 the consul reported that "several Moors" from Tangier wished

to ship livestock to Spain themselves, unloading it in Tarifa. And they have come back many times to ask for my permission, and lately Governor Ben Abdelmelek has done so; for himself he wishes to send two hundred oxen that he has here. For this I wrote to the governor, Don Nicolás de Macía Dávalos, [asking] if livestock belonging to Moors could be unloaded at that anchorage; and he answers that the same royal decree from the time of the Gibraltar blockade is still in force, [stating] that Moors can legally conduct trade only in Cádiz or Málaga. I have not told Ben Abdelmelek of this while I await Your Excellency's instructions on how to give a definitive answer to him and the other Moors who wish to pursue this line of business. ${ }^{55}$

52 J.M. González Salmón to Duke of La Alcudia, Cádiz, 11 October 1793, AHN, Estado, leg. 4331.

53 J.M. González Salmón to Muley Absalem, Cádiz, 28 June 1793, A HN, Estado, leg. 433 O.

54 Count Floridablanca to J.M. González Salmón, San Ildefonso, 12 July 1782, AHN, Estado, leg. 4316.

55 “...llevar Ganado por su quenta a España desembarcándolo en Tarifa, y repetidas vezes me han vuelto ha hablar para que les de mi permiso, y últimamente lo ha hecho el Governador Ben Abdelmelek que quiere mandar por su cuenta doscientos Bueyes que tiene aquí, por lo que escribí al Governador Dn. Nicolas de Macia Davalos, si se podría desembarcar por aquel surgidero el Ganado que vaya por cuenta de Moros, y me ha respondido que aun subsiste la misma Real Orden que en tiempo del Bloqueo de Gibraltar para que los Moros hagan su trafico solamente a Cadiz o Malaga en derechura, lo que no he dicho a Ben Abdelmelek aguardando las instrucciones que V.E. tenga por conveniente para satisfacerlo de una vez como igualmente a los demás Moros que quieren seguir este negocio": J.M. González Salmón to Count Floridablanca, Tangier, 11 June 1784, AHN, Estado, leg. 4317 . 
The growing number of Moroccan tradesmen crossing to Spain must have given rise to some difficulties: just a few days after their request to convey livestock directly to Tarifa, the Spanish consul's superiors ordered him to make it harder for Moroccans to reach the Peninsula. He was prepared to comply:

I will try to prevent the Moors who are asking to send their goods to Tarifa but, as Your Excellency instructs me, without denying them formally [the right] to frequent ports other than Málaga and Cádiz in Andalusia. In case the governor of this port should insist on sending the two hundred oxen he has spoken of (and of which I told Your Excellency in my letter of the 11th of this month), I will use all my skill to try to dissuade him and have him sell them here. But if I am unsuccessful I will suggest that they send them by some Spaniard who will care for them until he delivers them to the Moor who will receive them in Cádiz; then there will be no precedent for the others who wish to [engage in] the same trade, nor will it become known. ${ }^{56}$

Aside from Spain's attempts to limit or block the flow of Moroccan traders, an even more important factor would complicate the presence of North African merchants in Spain: the death of King Charles III in 1789, followed only a year later by that of Sultan Muley Muhammad ben Abdallah. The latter's death gave rise to open warfare among several of his sons who were rivals for his throne. Although Muley al-Yazid had himself proclaimed emperor and managed to conquer much of the country, his brothers continued to oppose him on the field of battle. Misunderstandings between the governments of Charles IV and Muley al-Yazid culminated in the Hispano-Moroccan war of 1791-1792. Still, commercial relations with Spain in the ports controlled by the sultan's quarreling brothers remained very fluid, and the sultan himself, like his father

$5^{6} \quad$ "Procuraré impedir a los Moros que solicitan embiar efectos por Tarifa, sin darles negativa formal, como V.E. me ordena, frequenten otros Puertos que el de Malaga y Cadiz en Andalucia; y en el caso que el Govenador de esta Plaza insista en querer mandar los doscientos bueyes que me ha hablado y a V.E. noticie en una de mis Cartas 11 del Corriente, haré con maña todo lo posible para disuadirlo, y que los benda aquí; pero si no lo consigo le propondré los embien en Caveza de algun Español, que cuida de ellos hasta entregarlos en Cadiz al Moro que destine; por tal de no hacer exemplar con los demás que dessean igual trafico, ni que el se pueda resentir": J.M. González Salmón to Count Floridablanca, 11 and 23 June 1764. AHN,Estado, leg. 4317. The sources do not reveal whether the Moroccans were ever able to accompany their cattle to Tarifa. 
in $1774-1775$, saw no reason for the new war to interrupt trade between the two countries. ${ }^{57}$

Shortly afterward a new factor favored participation by both Spanish and North African ships in direct trade with the southern shore of the Mediterranean: the French Revolution of 1789 , which inspired the Moroccan sultan and the Spanish monarch to close ranks against a Republican France that had beheaded its king and claimed to be guided by reason, not religion. The subsequent war between Spain and France in 1793-1795 removed all French vessels from Spanish-Moroccan trade. As a result Moroccan, Algerian, and Tunisian merchant ships began to enter timidly into that trade, helped by the narrowness of the Strait of Gibraltar, which they could traverse as neutral parties. ${ }^{58}$

\subsection{The Spanish Administration and Incidents That Arose from the Presence of Muslim Merchants}

As more Moroccan merchants traveled to Spain they generated several kinds of problems: pretensions to a false rank (usually by claiming to be envoys of the sultan), attempts to avoid the health regulations, ${ }^{59}$ participation in smuggling (often while acting as straw men for European traders), ${ }^{60}$ avoidance of import and export duties, and false claims against Spanish businessmen. Most significant of all were their attempts to supply food to the port of Gibraltar while it was being blockaded by the Spanish army and navy during the lateeighteenth-century wars between Spain and Great Britain. There were Moroccans who committed robbery, failed to pay their debts, or became embroiled in a variety of schemes; I will comment briefly on each group and name the merchants involved in them. In section 8.5 of this chapter I study these men

57 The Spanish consul reported that Sultan al-Yazid had ordered ports from Tetouan to Agadir to admit any Spanish ships that arrived for trading purposes: J.M. González Salmón to Count Floridablanca, 17 May 1791, AHN, Estado, leg. 433 O.

$5^{8}$ Although it concerns later years see Martín Corrales, "La flotte marocaine."

59 Moroccan vessels were subject to Spanish health legislation, which had been well organized ever since an outbreak of plague in Marseille in 1720. Its first objective was to prevent the spread of plague and other diseases, and with a few exceptions functioned well, at least until the spread of yellow-fever epidemics in the second half of the eighteenth century. Health policy was also a powerful weapon against vessels flying certain enemy flags and/or competitors of the Spanish merchant fleet. It was wielded particularly against British ships: Martín Corrales, Cataluña y el comercio, esp. Chap. 3 .

6o There is abundant evidence that the presence of Moroccan tradesmen in Cádiz and other Spanish cities gave rise to illegal practices, and that Muslim merchants were involved in numerous episodes of smuggling. But in fact almost all merchants, of every nationality and religion, took part in such activities. 
of business in detail and describe the more than thirty incidents with which they were connected.

First, we find the Moroccans who presented themselves falsely to the authorities as holders of a given office. They demanded to be received in a manner appropriate to their supposed status, and claimed to be entrusted with missions that in fact did not exist. These deceptions have been detected in the cases of some ambassadors and envoys (Vasif Effendi, Assan Aga Giritri, and Sidi Mahamet Sarjony) and ship's captains (Ibrahim Lubaris and Mate Flores). There were also merchants who resorted to these tactics, with variable results. We have seen in this chapter the case of Abraham Benisso, and must add those of the traders Mahamet Sarrax (who tried to have Spanish authorities house and feed him) and Jamet Bigga (who exaggerated his "rank"). Along with these were men who claimed in the proper form, though without justification, reductions in tariffs or the right to transfer European goods bound for Morocco from ship to ship inside the Bay of Cádiz: they include Absalem Bargas, Hamete Bargas, Jamet Bigga, and Sidi Mohamed Ben Muchafi.

As a general rule, Moroccan merchants adapted more readily to the prevailing sanitary regulations in Spanish ports than ambassadors and ship captains did. Still, some claimed that the quarantine had made them lose their goods and property: among them were Hamet Federico, Jamet el Bacal, and Hach Hamed Erzini.

Cases of smuggling or contraband involved Absalem Bargas, Jamet Bigga, Absalem Karassi, Hamant Sidon, and Abdifadil Yallul. In connection with contraband we include attempts to bring goods or money into Spain without declaring them, claiming ignorance of Spanish law: guilty parties included Absalem Bargas and Jamet Shebany. Hamet Almanzor, Hamant Sidon, and Benamar all tried to take money out of the Peninsula without paying the required duties.

Jami Maduni and Absalem Bargas were among the Moroccan tradesmen who brought foodstuffs into the English stronghold of Gibraltar while it was blockaded by the Spanish army and navy. For many Moroccans the AngloSpanish war of 1779-1783 presented a fine opportunity to profit from both sides, and there are many documented instances of smuggling. ${ }^{61}$ In 1780 it was

61 In November 1779 two Moroccans were arrested aboard an English vessel taking provisions to Gibraltar. They were handed over to the governor of Tangier, who detained them and notified the sultan, who nonetheless ordered them released as having suffered enough:J.M. González Salmón to Count Floridablanca, Tangier, 26 May 1780, AHN, Estado, leg. 4314. In August 1780 the Moroccan brigantine El Veloz was seized in Algeciras and its captain and crew sent to the sultan for punishment: Count Floridablanca to J.M. González Salmón, El Pardo, 25 August 1780, AHn, Estado, leg. 4316. 
reported that Moroccans were buying raisins and other products in Málaga and shipping them to Gibraltar. ${ }^{62}$ Although the sultan threatened those who indulged in this traffic, many were unable to resist the chance. In May 1780 the Spanish consul in Tangier reported on "the exorbitant profit accrued to these Moors by the foodstuffs (which they all have sent at their own expense): it has encouraged them to pursue this traffic ardently, for they have been offered as much as six hundred pesos fuertes for shipping forty oxen."63

The final group of Moroccans consists of those who stole (usually from their compatriots), failed to pay their debts (to Spanish merchants), were sent to prison, or committed other types of offenses. These included Caddur Ben Abú, Absalem Bargas, Hamete Bargas, Sarifey, Mohamed Barrada, Ahmed Karassi, Jamete Vinjut, Alraez Ben Alfaraed, Sidi Mahamet Mekani, and Zuizin.

\subsection{Both Monarchies Seek to End the Abuses}

The Secretariat of State, the consul, and local Spanish authorities were especially disturbed by actions of some ambassadors, envoys, captains, and merchants; they found their behavior incomprehensible and began to express their severe criticisms. Especially troublesome were the "envoys" who claimed false authority or rank, the presenters of impossible claims, and the liars. Soon their unease was extended to Moroccans in general. In 1784, during the negotiations for sending cattle to Tarifa that we described above, the Secretariat warned the Spanish consul not to trust North Africans:

We have had so many instances of bad behavior by Moors in our ports that we should not allow them to enter any one that they wish. For the

62 "Moors ... are in Málaga buying that fruit, in case the English ship it": J.M. González Salmón to Count Floridablanca, Tangier, 19 February 1780. The parish priest of the Spanish hospice in Tangier claimed that a vessel with a Spanish captain had been chartered to take a load of raisins, by "a Moor called Sidy Mahamet Mamón, to ship to this port three hundred fifty-five packets of that product," assuming they had been sold to the English: Fray Pedro Bejarano de San Antonio, Tangier, 19 February 1780, AHN, Estado, leg. 3414. In May of that year Moroccans sold to a Gibraltarian ship a cargo of six hundred arrobas of oil bought earlier by Moroccans in Cádiz: J.M. González Salmón to Count Floridablanca, Tangier, 12 May 1780, AHN, Estado, leg. 4314.

63 The port administrator of Larache, Tangier and Tetouan warned Moroccan smugglers that if the Spanish should seize them out of Moroccan or English ships and declare them slaves, the sultan would not object: J.M. González Salmón to Count Floridablanca, Tangier, 4 March 1780, AHN, Estado, leg. 4314. 
same reason I advise you, in reply to your letter of 27 March, that while not formally denying the Moors who wish to send goods to Tarifa you try to keep them from visiting any other ports except Málaga and Cádiz in Andalusia. ${ }^{64}$

Local authorities shared these feelings. José Veciana, military governor of the Granadan coast, expressed them after receiving instructions from the Secretary of State:

Let Moroccan Moors be treated with all the fairness, ready assistance, and proper administration of justice that they are due in the name of the good harmony that prevails between our court and that of Morocco. Most of them, however, do not deserve it because of their bad behavior, trickery, and lies, like those Your Excellency has experienced from the two Moors Jamet Vargas and Sarifey, who have had the atrocious audacity to irritate you and try to deceive you.

He added that any who arrived on his coasts would be issued the necessary passport, but would be prevented from traveling to Madrid:

I will ensure that none shall be given a passport or license to proceed to the Court unless there is an order from above, as Your Excellency tells me. But since they are able to leave without those documents and move without them from one town to another in the Peninsula - something I believe is not forbidden to them - we can only inform them when they reach our ports that they must not go to Madrid without obtaining permission from a superior, on pain of being treated and punished as vagrants. ${ }^{65}$

64 "Son tantas las experiencias que tenemos de la mala conducta de los moros en nuestros puertos que no conviene facilitarles pasen á todos los que quisieran. Por lo mismo prevengo á $\mathrm{Vm}$. en respuesta a una de sus carta[s] de 27 de marzo que sin dar una formal negativa á esos moros que solicitan enviar efectos a Tarifa, procure impedir que frecuenten otros puertos mas que el de Malaga y Cadiz en Andalucía": Count Floridablanca to J.M. González Salmón, 18 May 1784, AHN, Estado, leg. 4316; also the draft, Aranjuez to J.M. González Salmón, 18 May 1784, AHN, Estado, leg. 4317.

65 "[S]ean tratados con toda equidad, buena asistencia, y recta administración de Justicia los Moros Marroquíes, que aportaren a ellos, mediante la buena armonía, que reyna entre nuestra Corte, y la de Marruecos, sin embargo de que los mas de ellos lo desmerezcan por su mala conducta, artificios, y mentiras semejantes á las que ha tocado V.E. en los dos Moros Jamet Vargas, y Sarifey con la atroz audacia de molestar, y querer engañar a V.E. ... Cuidaré de que a ninguno se le libre Pasaporte, ó Licencia para pasar a la Corte sin que preceda orden superior, según V.E. me lo previene; pero como ellos podrán marchar sin 
Problems must have begun soon, because in early 1787 the Secretariat of State told the consul that more and more Moroccans were arriving at court with their demands: "It happens that Moroccan Moors have decided with some frequency to come to Madrid, and they are causing annoyances both at court and at the summer residences." It was ordered that the ports specializing in trade with Morocco (Cádiz, Málaga, Alicante, and Barcelona) prevent those men from traveling further: "Let none of them come to Madrid without a prior permit or passport issued by this Secretariat of State; also, let the Governor of Cádiz understand that most of the Moors who travel to that city, having no funds of their own or reputation for commerce, are the conduit that some businessmen from there use for their contraband activities."

The Spanish consul was urged to make prudent use of any information he received, so that he could be seen to treat Moroccans properly, "not intending to cause these people any unpleasantness with [their] sovereign, but so it may never be thought that we fail to treat the vassals of that monarch with all possible attentions." 66

In the same year Consul Juan Manuel González Salmón, who knew Morocco better than most men of his time, granted that Moroccans gave trouble at court but advised that it was better not to tell the sultan about it:

... without reporting the least complaint about such people to His Moroccan Majesty, though I know that that monarch's intent is very different from the conduct that his vassals generally display in Spain: he absolutely wishes them to cause no scandal, especially to do with women or wine, and to commit no fraud, for he detests the very word contraband and when he hears it grows irritated and then enraged. Since [his subjects] know this, there is no better way to control them and make them hear reason than to warn them that they will be sent here [to Morocco] as prisoners with a report on their conduct, so that the king of Morocco may punish them as he sees fit. I know that by the order issued to the ports of Cádiz, Málaga, Alicante, and Barcelona they will be prevented from going to Madrid; but those who are there now can be asked or even forced to leave if they have no legitimate business. There is no fear that

tales documentos, asi como transitar sin ellos de unos Pueblos a otros de la Peninsula, lo qual me parece no estarles prohibido: Solo queda el arbitrio de hacerles saber quando arriben a nuestros Puertos, que no deven presentarse en la Corte, sin obtener superior permiso so pena de ser tratados, y castigados como vagantes": José Veciana to Count Floridablanca, Málaga, 8 June 1784, A HN, Estado, leg. 4317. 
His Moroccan Majesty will cease to believe in and feel the attentions and favors that we offer his vassals. And I will do everything I can to ensure that from now on the Moors who come to our ports are men of good faith and guaranteed conduct. ${ }^{67}$

He agreed with the Secretariat of State about the Moroccans' behavior:

The Moors, honored Sir, are generally arrogant and unruly when they are outside the control of their own sovereign if they realize that their impertinence is tolerated; and on the contrary, if they are made to feel fear one can do what one wants with them. They have a tendency to contraband because they are ruled by greed, but if [a Moor] is apprehended you would do well to send him here using the same deception in which he himself was caught. I dare say that making just one example of someone will serve as a warning to all the rest, since then no Moor will decide to engage in illicit trade on his own or others' behalf. But if you treat them with just a little special indulgence they become insufferable. ${ }^{68}$

67 “...sin dar contra essa Gente la menor quexa a S. M. Marroqui, pero constándome que la intencion de este Monarca, es mui distinta de la conducta que generalmente guardan sus Vassallos en España, pues absolutamente quiere que dén el menor escandalo, particularmente si es con Mugeres ó por el Vino, ni tampoco que hagan fraudes porque hasta abomina la voz de Contrabando, y quando la oye, se irrita, y transforma en cólera. Conociendo ellos esto mismo, no hay mejor medio para sugetarlos, y hacerlos entrar á la razón, que amonestarles de que se mandarán aquí presos con noticia de su conducta, para que el Rey de Marruecos los castigue á su voluntad; bien que ya se de la providencia que se a tomado con la orden dada a los Puertos de Cádiz, Málaga, Alicante y Barcelona, se cortará el passo de ellos para essa Corte, pero a los que en el dia están, se les puede requerir, y aun obligarlos a salir de ella, al que no tenga ocupación legitima, sin el menor recelo de que caiga en la creencia y sentir de S. M. Marroqui las atenciones y condescendencias que usamos con sus Vassallos, y procuraré quanto me sea posible para que en lo sucesivo los Moros que passen a Nuestros Puertos sean hombres de crédito, y conducta abonada" (underline in the original): J.M. González Salmón to Count Floridablanca, Tangier, 12 March 1787. AHN, Estado, leg. 4319 .

68 "Los Moros, Señor Exmo, son generalmente altivos, y revoltosos quando se hallan fuera de la dominación de su mismo Soberano si llegan a comprehender que se les disimula sus impertinencias, y por lo contrario si conciven algun temor se hace de ellos lo que se quiere. Son propensos al Contrabando por que los domina el interez, pero si quando se coge alguno tiene V.E. a bien mandar que se envie aquí con el mismo fraude que se le haya encontrado, me atrebo a asegurar que con solo un exemplar de estos sirve de escarmiento para todos los demás, y que ningun Moro se determina á hacer Comercio ilisito, suyo propio ny ageno, pero en tratándolos con alguna indulgencia particular son insoportables": J.M. González Salmón to Count Floridablanca, Tangier, 12 March 1787, AHN, Estado, leg. 4319 . 
The sultan was equally unhappy with his subjects' conduct on Spanish soil. We recall that in the Treaty of Peace of 1767 and the Agreement of 1780 , almost no attention was paid to the rights and obligations of Moroccan merchants in Spain, and the sultan hoped to suppress their illegal activity; he was afraid of its possible negative impact on his foreign policy. On several different occasions he commanded that his people not embark for a Spanish port without a passport from Spain's consul in Tangier.

In January 1788 the sultan alerted the consul: he had heard from "certain trustworthy persons that Moors who go to Christian lands to trade, and who embark in Tetouan, entertain themselves and do things that true believers should not do; and when we heard this we were seriously displeased." He therefore told the consul not to allow any Moroccan to take ship "unless you know that the Moor who seeks to embark is a man of good sense, good conduct, and religion." Besides, he should issue a letter of reference for the governors of the proposed ports of call, and a passport or safe-conduct stating "the length of time that [the bearer] plans to stay in the Christian land." The Moroccan traveler "shall not remain any longer than what the paper says, and if he does so no one shall be blamed except himself." The sovereign asked the consul to report to him monthly on the men who embarked and the merchandise they carried; further, if the merchants took servants those too should be "men of conduct and religion."69

The consul reported to the Secretary of State that in fact the sultan had received his information from "a Moor said to be Tunisian." That man had told the monarch that Moroccan traders who embarked in Tetouan for Europe "show bad behavior, being drunk and disorderly." Hence the sultan's orders, especially those ensuring that merchants had a permit issued by a European consul in Tangier. González Salmón suggested that his superior read the sultan's letter "to those Moroccan Moors who are now in Madrid or in this residence [Aranjuez], so that, if they do not withdraw as the sultan commands, they cannot claim afterward that the order was not explained to them or that they did not understand it."70 Still, it does not appear that the prohibition was effective: later, Spanish authorities had to be asked again not to admit any Moroccan who lacked a passport from the Spanish consul. ${ }^{71}$

69 Letter from the sultan to J.M. González Salmón, 25 January 1788, AHN, Estado, leg. 4321.

70 The consul also reported having sent a copy of the letter to the governor of Cádiz, to be read to the "Moroccan Moors who are in that port": J.M. González Salmón to Count Floridablanca, Tangier, 11 February 1788, AHN, Estado, leg. 4321.

71 Count Floridablanca to J.M. González Salmón, Aranjuez, 10 June 1788, AHN, Estado, leg. 4316. 
In June 1788 the sultan ordered "all Moors his vassals who are in Spain to leave it," granting them until year's end so that they could "finish off their business before their departure." The Spanish and Moroccan courts were sometimes surprisingly synchronous in their decisions: in July the Spanish consul learned from his superior that the king had heard about the sultan's command. A circular notice stated: "they [the Moors] should be told that it is His Majesty's wish that what that monarch [the sultan] has decided should be done." Again, they were allowed to remain in order to settle their affairs until the end of the year. ${ }^{72}$

The Spanish consul told the sultan the news, hoping that "he would be pleased to hear of it." He himself was glad that the Moroccans would be leaving: "it will be useful for us as well, for Spain will be rid of many Moors who usually take part in smuggling and other evil acts." 73

We do not know if every Moroccan returned home, and in fact the passport requirement was often ignored by both Moroccan and Spanish officials. In 1788 Mahamet Sarjony appeared in Tunis, Palma de Mallorca, and Ceuta claiming to be an ambassador from Morocco, and without either a passport from the consul or a letter from the sultan he managed to be received as a diplomat in Palma and Ceuta. The Secretariat of State reminded the Spanish consul, the admirals of the various regions, and the governors of the North African presidios that a decree of 1775 had required "that when Moroccan Moors appear without a letter from His Majesty's consul in Tangier explaining their mission, character, and proper form of address, they should receive only the treatment necessary to maintain our good harmony with the King of Morocco."74

We observe a certain ambiguity in the requirement of a passport for merchants, travelers, and others. In any event, in spite of the difficulties that Moroccan merchants encountered, they did manage to form a permanent colony on Spanish soil.

72 The bulletin also repeated the order that "no Moroccan vassal shall be admitted to Spain unless he bears a passport or letter from you recommending him": Aranjuez, undated draft [June 1788] with no addressee, AHN, Estado, leg. 4321.

73 J.M. González Salmón to Count Floridablanca, Tangier, 23June 1788, A HN, Estado, leg. 4321.

74 Count Floridablanca to J.M. González Salmón, Aranjuez, 10 June 1788, AHN, Estado, leg. 4316. 


\subsection{Members of the Moroccan Merchant Colony}

In this section we will tell the stories of some of the Moroccan merchants who were active in Spain. They were numerous enough to allow us to speak of a permanent Moroccan colony, whose members spent shorter or longer periods in the country. Almost all of these were involved in some kind of problem with the authorities, in illustration of what we noted in the previous paragraphs.

Most of these traders and pursers, however, caused no significant conflicts and therefore leave no traces in documentary sources; therefore our information about this colony can be only partial. ${ }^{75}$

\subsubsection{Jachi Mostafá(1779)}

In October 1779 the military governor of Madrid, Cristóbal de Zayas, wrote to the Secretary of State (who was in San Lorenzo de El Escorial) about the arrival of "a Moroccan Moor named Jachi Mostafá, a free man and a trader by profession." He bore a passport issued by the governor of Cartagena that noted his arrival there in one of a fleet of Sicilian war frigates. He intended to go to Marseille "on personal business," claiming that "he has an urgent need to wait on Your Excellency, for which he asked asked me for permission to visit that residence [El Escorial]." 76 Permission was granted "provided that he plans and pays for the journey himself, because since he is traveling of his own will and is not sent by the king of Morocco there is no reason [for us] to bear the cost."77

\subsubsection{Ahmet Bodinach (1780)}

In about 1780 we find Ahmet Bodinach trading in hides in Málaga and Barcelona. In March of that year he was forbidden to sell in Barcelona a load of hides and other items that he had sent from Málaga, "from which he had taken them after not having found there the profits he expected from their sale." He petitioned the Count of Floridablanca and had the prohibition lifted. ${ }^{78}$

\subsubsection{Aly Castillo (1780-1787)}

Aly Castillo introduced himself as "a Muslim by birth, a citizen of Tetouan and a resident in this court [Madrid]." He had reached Spain as an interpreter to Ibn Utman during his first embassy in 1780 : "He had the honor of acting as

75 I have not cited, however, documents related to dozens of Moroccan traders, captains, and pursers who conducted business in Spain but caused no detectable problems.

76 Cristóbal de Zayas to Count Floridablanca, Madrid, 21 October 1779, A HN, Estado, leg. 5802.

77 San Lorenzo de El Escorial to Cristóbal de Zayas, 23 October 1779, AHN, Estado, leg. 5802.

78 Імнв, Fs, Serie v, leg. 11, fols. 119-20, 20 June 178 o. 
Interpreter in the recent embassy that the king of Morocco sent to Your Majesty with Si[di] Mohajamet Benozman [Ibn Utman] in order to become acquainted with this country. Therefore the petitioner decided to come to this court to establish his business." That was what he did, "opening a shop and forming a company with Absalam Vargas [or Bargas] of his own nation."79 In 1786 the Diario de Madrid reported that "in the past few months three shops belonging to Moroccan Moors have been opened in this city," one of them in "Puebla Vieja Street, whose merchant is named Alí, a native of Tetouan, and he sells the following: slippers for men and women, kerchiefs, skirts, and several other items made of cotton, as well as carpets and dates." 80

As Aly Castillo was to explain in July 1787, problems soon arose with his partner Vargas:

[Castillo]'s company lasted from the the king's soujourn in La Granja [in the summer] to his stay in Aranjuez [in the spring]. At the beginning of the latter Vargas asked for an accounting and claimed that he had lost two hundred duros through fault of the petitioner, who stripped him of everything and abandoned him without returning even what remained of his investment, which was twenty-five duros.

Aly claimed to be the victim of Absalem Vargas's "bad faith," and sought aid from

the governor of the Council and that of the royal summer residence of Aranjuez, in whom he found all possible justice and protection. But since Vargas denied the facts, and proof of these was needed in Madrid, and since the petitioner saw in the courts the delays, annoyances, and heavy fees that any suit causes, which he could not assume by any means because he had no money, he has been obliged to defray [satisfaction] for his own country, where he will find justice without costs or delays. ${ }^{81}$

79 Petiton by Aly Castillo, Madrid, 7 and 16 July 1787, AHN, Estado, leg. 5803, Exp. 8 (34).

80 Diario de Madrid, 18 September 1786; cited in Sarasúa, Criados, 138.

81 “...cuia compañía ha durado desde la Jornada de la Granja hasta la de Aranjuez al principio de la qual figurando Vargas un ajuste de cuentas, y que de el resultaban perdidos doscientos duros por culpa del suplicante, le desposeio de todo dejándole abandonado sin darle ni aun el resto de su parte de caudal, que eran veinte y cinco duros...Governador del Consejo y el del Real Sitio de Aranjuez en quienes halló toda la Justicia, y Proteccion imaginable. Pero como Vargas negó los hechos, y estos se debían justificar en Madrid, y judicialmente viendo el suplicante las dilaciones molestias y crecidos gastos que ocasiona qualquier Pleito, y que el no podía hacer absolutamente por no tener dinero se ha visto 
Though discouraged and wanting to go home, "he also lack[ed] the means to return" and asked the Secretary of State for help, "some alms to help him go back to Tetouan." A note on his case suggests that he was believed: "There are bad reports about Abasalen Vargas even in Tangier according to a letter from [González] Salmón of 12 March of this year, after he also importuned us here with his demands." Aly's departure presented no difficulty: "Let him be gone," the note adds. ${ }^{82}$

\subsubsection{Hach Jami Maduni (1780)}

In September 1780 the Secretariat of State expressed satisfaction at the punishment imposed on Hach Jami Maduni "for having twice introduced foodstuffs into Gibraltar, breaking the Spanish blockade." It hoped that his case would set an example to others who might consider doing the same. At the same time, the Spanish consul in Tangier was ordered to "help ensure that the king of Morocco does not take Hache Jami Maduni's life or treat him harshly ... the king does not require such an extreme measure to be assured of His Moroccan Majesty's good intentions in this regard." ${ }^{33}$

\subsubsection{Mahamet Sarrax (1781)}

The sultan sent this merchant from Tetouan to Cádiz to buy cochineal worth thirty thousand pesos fuertes. He enjoyed Spanish protection from the consul in Tangier and the governor of Cádiz, but before leaving Tetouan he clashed with the former: he claimed that by the sultan's order he should be lodged in the consul's house until he sailed for Cádiz. The consul's complaint is eloquent:

He appeared at this house (with the pride and arrogance that these natives display when they come on an errand from their sovereign) with the said sum of money, telling me that His Moroccan Majesty had ordered him to come here and be my guest until he embarked. Knowing that it was all an invention - for I had heard from the governor of this port that his Majesty had only requested a ship for him to carry the money in I answered that I had received no such order.

precisado a dejarlo para su tierra, donde conseguirá justicia sin gastos, ni dilación": petition by Aly Castillo, Madrid, 7 and 16 July 1787, AHN, Estado, leg. 5803, Exp. 8 (34).

82 Note on his file with an instruction to inform Anduaga, 16 July 1787, AHN, Estado, leg. 5803, Exp. 8 (34).

83 The man is also called Tami Maduny and Tami Dun; the sultan had his sons put in chains. See two draft letters sent from San Ildefonso to T. Bremond, 19 September 1780; also T. Bremond to Count Floridablanca, 21 September 178o, AHN, Estado, leg. 4313. 
He refused to lodge Sarrax without an express written instruction from the sultan: "My reply annoyed him greatly, and he retorted that even though he had no explicit order from the king his master he did not expect to be received in such a manner."

González Salmón offered to receive him "as a private friend"; though that was "very strange, since I am in his country, I was happy to do it." The governor of Tangier, on being applied to, confirmed that Sarrax had no such order and "upbraided him severely." The consul knew that he would behave the same way in Cádiz: "The Moor obviously thought that just because he was charged with going to Cádiz on his sovereign's private business I should house him until he embarked. And I assure Your Excellency that he believes his stay in that city will come at the expense of the Royal Treasury." Further, Sarrax would not show gratitude for favors: "Any consideration offered him is fruitless, because this individual and many others of his type are incapable of ever acknowledging a benefit; and much less does he enjoy any credit with the monarch." 84

The consul warned Governor O'Reilly of Cádiz that Sarrax would surely petition there for "what is needed for the daily support of himself and his family." He advised treating him "on the same terms as any other Moroccan subject, with only the preference needed for providing him with what is necessary for the speediest possible dispatch of his commission." 85

\subsubsection{Caddur Ben Abú (Caddur de Bargas) (1781)}

In 1781 two Spanish merchants, José García from Málaga and Luis Gabarrón from Estepona, sent a petition to the king. They complained that Caddur de Bargas (actually Caddur Ben Abú) from Tangier had arrived in Málaga early that year and had dealt with them in cash, figs, raisins, and saffron. According to documents witnessed in Málaga, the Moroccan "would be up-to-date and make no delay in paying for everything," making Caddur's father Abdu Ben-Adrajama, "who was a rich man and respected in Tangier, site of his residence," the responsible party. García had given him a total of 12,227 reales de vellón and Gabarrón 326 pesos fuertes, both amounts in a combination of cash

84 "Se me presentó (con la sobervia y altivez que acostumbran estos Naturales quando trahen alguna comisión de su Soberano) con dicho dinero en esta Casa, diciéndome tenia órdenes de S. M. M. para venirse á ella y estar a mi disposición hasta su embarque. Conociendo yo todo era supuesto, pues solo se me havia prevenido por el Gobernador de esta Plaza, y de orden de S. M. M. le facilitase embarcación en que fuese con el dinero, le contesté que a mi no se me havia leído tal orden”: J.M. González Salmón to Count Floridablanca, Tangier, 3 December 1781, AHN, Estado, leg. 4312.

85 J.M. González Salmón to O’Reilly, Tangier, 3 December 1781, A HN, Estado, leg. 4314. 
and product; García's felucca had taken a cargo of raisins, figs, and saffron to Tetouan in June but were not paid by either Caddur or his father, who refused to receive them. The latter declared before the Spanish consul that he knew nothing about his son's contracts, and that "because he is in a state of extreme poverty he cannot respond to nor satisfy any demand at all." The consul investigated and concluded that this was true: the father could not even pay for his daily needs. ${ }^{86}$

Gabarrón and his purser were forced to sell their products cheaply to avoid further losses; they denounced Caddur and asked for recompense, claiming that the friendship between "the Spanish Crown and the Empire of Morocco" should not be endangered by such "serious inconveniences, with wellknown harm to the state and the public trust." They demanded that Abdu Ben-Adrajaman, his son being insolvent, return the money invested in the expedition to Tetouan: ${ }^{87}$ they set the amount at 13,117 reales de vellón. The Spanish consul explained that normally in Spain, when any loan was requested, the potential borrower was investigated thoroughly - among other reasons, to determine if he could replay the debt in case of difficulties. Therefore,

it is strange how readily they entrusted their funds to the Moors, as we see with these two men: without any other assurance than Caddur's claim that his father was a rich and respected man in this [city], they handed him the sum in question in goods and cash. They did not consider that just as [the Moor] lacked enough for his immediate needs, his bad or irregular conduct in that city and his very character - which is clear at first glance - were sufficient warning of the blow they are suffering.

In this the Secretary of State agreed: he had thought that the Spanish businessmen had acted "too lightly" and should be "more careful in the future." The consul went further, expressing his "astonishment at our Spaniards' generosity with these natives." Almost all Moroccans who chartered ships for Spanish ports borrowed from their captains:

One man four hundred, another six hundred, even a thousand pesos fuertes; and this from individuals who cannot command even one

86 J.M. González Salmón to Count Floridablanca, Tangier, 30 November 1781, AHN, Estado, leg. 4314 .

87 Petition by José García and Luis Gabarrón, Madrid, 4 October 1781. Count Floridablanca to J.M. González Salmón, San Lorenzo de El Escorial, 16 November 1781, AHN, Estado, leg. 4316 . 
hundred. If [the Moor] suffered a reverse of fortune our people would be left with nothing, and many would have fallen behind in their payments if I had not thought to tell them never to unload from their ships sufficient merchandise to satisfy their debts until the money had been paid.

The consul was proud that thanks to his intervention, no Spanish captain had emerged the worse from this kind of trade:

Becoming aware of the harm done by Caddur Ben Abú (that is his true surname) in Málaga, in addition to asking the Count of Xerena on 26 June to force him to come to this kingdom, I informed Governor BenAbdelmelek. He promised me that as soon as [Caddur] returned to these domains he would not go again to those of the king our master; and that those who went in the future would be men of good behavior and repute so as to avoid disagreements. And in fact he has done this, for he does not give a license to everyone.

He decided not to tell the governor of Tangier about Caddur's debts - since neither he nor his father were able to pay them - until he had consulted the Secretariat of State. The notion of reciprocity is clear in this case: "Once the governor receives the funds, I believe he should do the same with the four thousand or so duros that Don Juan Miguel Díaz, a native of Vornos, still owed to several vassals of His Moroccan Majesty after the last peace." 88

88 “[E]xtraño la facilidad con que franquean sus caudales a los Moros, como se bé en los dos mencionados que sin mas informes que haverles dicho el citado Cadur que su Padre era hombre rico y bien acreditado en esta, le proporcionaron en efectos y dinero hasta la expresada suma, sin considerar que por lo mismo que se hallava sin lo necesario para sus principales urgencias, la mala, o desarreglada conducta que el Moro tubo en aquella Ciudad, y su propio carácter que a la primera vista manifiesta lo que és, eran suficientes avisos para precaver el golpe que estan experimentando. ... Quien quatrocientos, quien seiscientos, y mil pesos fuertes; y a sujetos que no son Dueños ni aun de ciento, de manera que si tubiesse un revés de fortuna se quedarían los nuestros sin sus caudales, y muchos hubieran experimentado considerables atrasos a no haver tomado yo la providencia de mandarles que jamas consintiesen sacar de sus Buques los efectos considerasen suficientes a cubrir sus créditos, hasta que estos se les satisfaciesen. ... Noticioso yo de lo mal que se producia el referido Cadur Ben Abú (que es su lexitimo apellido) en Malaga, a mas de haver escrito en 26 de junio al Exmo.Sr.Conde de Xerena, lo hiciese benir a este Reyno, informé de ello al Gobernador Ben-Abdelmelek quien me prometió que luego que regresase a estos Dominios no volveria a los del Rey N.S. y que los que fuesen en adelante serian hombres de conducta, y crédito para evitar desavenencias, lo que en efecto cumple pues no le permite a todos la Licencia": J.M. González Salmón to Count Floridablanca, Tangier, 3o November 1781, AHN, Estado, leg. 4314. 


\subsubsection{Absalem Bargas (1781-1787)}

In 1781 Absalem Bargas, ${ }^{89}$ a "Moroccan Moor" from Tangier, was conducting business in Málaga and Barcelona. That year he sailed from the first city to the second in the caïque Nuestra Señora del Carmen y Ánimas under Captain Manuel González, with a cargo of hides. In Denia they loaded dried figs, raisins, onions, and garlic, "and in company with that Moor they were able to enter the enemy port [Gibraltar] on 13 November and sell all their products." 90

We already met Bargas in September 1786, when he was operating a shop in Madrid with Aly Castillo as his partner; Castillo sued him for having appropriated part of his original investment. ${ }^{91}$ The shop must have closed after that incident, since almost at once Bargas petitioned the Secretary of State: introducing himself as "a native and resident of the city of Tangier," he claimed to have been trading in Spanish ports, especially in and around Murcia, for seven years. Now he hoped to settle in Cádiz, and offered to serve without pay as an assistant to the port's interpreter:

He has been trading in Spain for seven years, and therefore is used to dealing with the natives of these kingdoms; and he knows their peoples fairly well, especially in the seaports of the Mediterranean coast, the Kingdom of Murcia, and others farther inland, where he has dealt and traded with them. And wishing to settle in Cádiz to trade in products of his country, since that is the port to which most of his compatriots arrive and in which the greatest number of lawsuits and issues with them occur; and since the interpreter in that port is now very old and in very poor health and almost decrepit, so that the Moors do not wish to deal with him, and most decide to come to Madrid and annoy Your Excellency and the other ministers of His Catholic Majesty to arrange their affairs; that could easily be avoided if Your Excellency would honor and protect this petitioner by naming him assistant interpreter of the port and Bay of Cádiz and its environs, without any salary, while the one who is there now still lives. Likewise in view of the damage the petitioner suffered a year ago when, because of a violent storm, he lost a ship loaded with 2,300 fanegas of wheat off Cabo Espartel. Also, he has sufficient knowledge of the Islamic language.

89 He also appears in the sources as Absalem de Bargas, Absalen Vargas, and Absalem de Vargas.

90 J.M. González Salmón to Count Floridablanca, Tangier, 5 February 1781, AHN, Estado, leg. 3414 .

Petition by Aly Castillo, 7 July 1786, AHN, Estado, leg. 5803 . 
At the same time he offered to transmit to the Secretary of State all the news about Morocco that reached him in Cádiz. ${ }^{92} \mathrm{He}$ also asked permission to import Moroccan wax into Cádiz, hoping to pay for the privilege at a rate of only three duros per quintal instead of the usual five; he would invest the profits in fabrics from other European countries and hoped to transfer them within the Bay of Cádiz so as not to pay the required duties. The Secretary of State, on receiving these requests, referred the matter to the Royal Treasury:

The Moroccan Moor Arselen de Vargas stated four months ago that he asks to pay only three duros instead of five per quintal on a shipment of wax that he is expecting from his country. And since he cannot export the wax from Cádiz and plans to receive [its value] in fabrics that will come into Cádiz, he asks permission to transfer them without paying taxes. He is willing to have them inspected in case there is suspicion of contraband, and will ferry them to shore in a small boat. ${ }^{93}$

The Treasury noted that by the royal decree of 22 August 1786, goods could not be transferred within a port from one vessel to another because the practice

92 "Hace siete años está comerciando en España, por cuio motivo se halla ya impuesto en el trato con los naturales de estos Reynos, y tiene bstante conocimiento de sus Gentes de ellos, maiormente en los Puertos de Mar de la Costa del Mediterraneo, Reyno de Murcia y otros de tierra â dentro, con quienes ha tratado, y comerciado; y deseando establecerse en Cadiz con el comercio de generos de su Pais, siendo este el Puerto donde mas vienen sus compatriotas, y en el que mas acaecen algunos pleitos, e historias con ellos; siendo ya mui anciano el Ynterprete que ay en aquel Puerto, y estar mui achacoso, y quasi decrepito por lo que los Moros no quieren tratar con el, y para tratar de sus asuntos determinan los mas venir á la Corte a incomodar a V.E. y demas Ministros de S.M.C. lo que se impediría con gran fazilidad mereciendo el exponente que V.E. le honrase, y protegiexe con el nombramiento de ayuda de Ynterprete de dicho Puerto, y Baia de Cadiz, y sus inmediaciones, sin sueldo alguno, interin viva el que en el dia ay atendiendo a que el proponente tuvo la desgracia un año hace, de que por causa de un fuerte temporal, perdió una embarcazion cargada de trigo que aszendia a 2300 fanegas en Cavo Espartel; y posehiendo suficientemente el Ydioma Yslamico." Bargas signed his statement in San Ildefonso [El Escorial], 15 September 1786, AHN, Estado, leg. 5803 .

93 "El moro Marroqui Arselen de Vargas dicho ha quatro meses que solicita la gracia de que solo pague 3 duros en lugar de 5 por quintal de una porción de cera que aguarda de su país; y mediante que no puede sacar de Cadiz el producto de la cera y piensa recibirlo en lienzos que vendrán al mismo Cadiz, pide el permiso de poderlos transbordar sin que paguen derechos, estando pronto a que se registren en caso de duda de contrabando, pasándolos a tierra en barco chico": unsigned report to the Secretary of State, 7 September 1786. The case was passed on 16 September to Pedro de Lerena, Secretary of the Treasury, for his opinion: AHN, Estado, leg. 5803 . 
facilitated fraud and smuggling. Granting Bargas's wish would set a bad example and every other "nation" would ask for the same favor: "therefore an exception has been denied to that Moor, and it would be imprudent to agree to the [request] Your Excellency has just sent." ${ }^{\prime 4}$ In spite of this denial Bargas because of his position or his doggedness - found it relatively easy to approach the Secretary of State, who confessed to having diverted him to the Treasury even after admitting that "his request is unfounded. ... I have already told him so in person." 95

Bargas had great enemies among members of the Moroccan colony. In August 1786 "a Moor from Madrid" (actually Aly Castillo, who signed his petition in Arabic) denounced him to the Secretary of State: he held a low opinion of Bargas and observed that "the laws of fairness prescribed by our religion may be corrupted and disrespected by men of no merit." He added,

The Moor Bargas has arrived here with the view and claim that some gold dust seized in Cádiz from an Algerian (now returned to his own country), who had contracted with a Frenchman who owned the gold, should have yielded him forty reales, which it seems is half the worth of this amount of gold. If he kept his word to get him through the door [at court] it would be returned to him, he pretending to be the said Algerian.... As an honest man I must act to prevent such an abuse. ${ }^{96}$

The warning did not fall on deaf ears, and a note was added to the file on Aly Castillo: "There are bad reports of Abasalen Vargas even in Tangier, according to [González] Salmón's letter of 12 March of this year, after he importuned us here with his demands." 97

Bargas, not surprisingly, complained about not receiving from "the Ministry of the Treasury several favors he ha[d] requested," so he applied for a license to

94 Pedro de Lerena to Count Floridablanca, San Ildefonso, 25 September 1786, AHN, Estado, leg. 5803 .

95 Unsigned and undated draft, AHN, Estado, leg. 5803.

96 "El Moro Balgas ha llegado á este sitio con la mira y pretensión de que cierto oro en polvo que en Cadiz fue apresado a otro Argelino (quien se marchó a su tierra) que havia contratado con un Frances dueño de el expresado oro le havia de dar 40 reales que al parecer es la mitad de el importe de esta porción de oro si cumplia con su palabra de pasarlo de la puerta se le restituia á el pretextando ser el Argelino mencionado. ... [C]omo hombre de bien devo impedir semejante abuso": Madrid, 11 August 1786. Signed in Arabic, AHN, Estado, leg. 5803 .

97 Petition by Aly Castillo, Madrid, 7 July 1787. The note on his file, with a request to inform Anduaga, is of 16 July 1787, AHN, Estado, leg. 5803, Exp. 8 (34). 
take one hundred thousand pesos fuertes out of Spain, a sum he claimed was "the value of the goods he imported and the transfer of one hundred chests of linens." He also asked,

to redeem some of the inconveniences he has suffered, to be allowed to pay four percent on taking out of Cádiz one hundred thousand pesos fuertes that he earned from the goods he had imported and has sold in that port. Also, to be able to transfer within that bay one hundred chests of linens so as to ship them to his country, without these goods touching any land in Spain: a Customs Minister can come aboard the vessel, as a pilot does, to guide them to his coast, being paid the usual daily rate until the date of sailing. This will obviate all suspicion or doubt of contraband, in which he has never intended to participate nor to disobey your royal decrees. $^{98}$

Once again the petition was forwarded to the Treasury, though it was thought to have no merit: "tell the Moor to go there although his request is unfounded. I have already told him so in person."99 Bargas obviously had little chance of getting his wish, since if granted it would further complicate the efforts to control smuggling in the Bay of Cádiz. In another petition he defended himself on the grounds that he was established "in business in Cádiz," and claimed that in Morocco Spaniards were treated better than other foreigners, a way of saying that the privileges the sultan offered the Spanish should be matched by those offered to Moroccans in Spain:

Five months ago he came to your court and royal summer residences to discuss several business propositions with your ministers, promising to pay the necessary duties to your Royal Treasury. Everything he requested has been denied, perhaps because it would not profit your Royal Treasury.

$98 \quad$ “...para poder redimir parte de las vejaciones que ha experimentado, se digne concederle la grazia de que pagando el quatro por ciento, pueda extraher de Cadiz cien mil pesos fuertes que ha sacado de los generos que introdujo, y ha vendido en dicho Puerto. Y asimismo poder transbordar en la referida Bahia cien Cajas de Telas de Lenzeria para transportarlas a su Pais, sin que estos Generos salgan en tierra alguna de España; poniéndose como en practica un ministro de Rentas a Bordo de la embarcazion que los ha de conducir a su costa pagandole la dieta regular que se acostumbra hasta el dia que se haga a la Vela: con lo que se obiará toda sospecha ó rezelo de contrabando en lo que jamas ha pensado contravenir, ni quebrantar vuestras Reales Ordenes": petition signed in Spanish and Arabic, San Lorenzo de El Escorial, dated 3 November 1786, AHN, Estado, leg. 5803 . 
But since all was in accordance with usual business practice in Spain, it is strange that he has not been satisfied in part of what he asks for, since it is publicly known that in his own country, in every port and town, his monarch has assisted and favored all Spaniards above the other nations of the earth, for example: a Spaniard who buys loads of wheat pays duties of four reales less per fanega than other nations, of course when they export it to other kingdoms. If [Spaniards] purchase cattle they are done the same favor in that they pay only sixty reales per head, while other nations and foreigners who take them to Gibraltar and other places pay one hundred reales de vellón per head. And likewise with other victuals and goods exported from that kingdom: every Spaniard is charged at least one-third less than all other nations. ${ }^{100}$

Whenever a Spaniard asked a favor of the Moroccan sultan, "instantly, without the least delay, it has been granted, making sure that he incurs no expenses or disadvantage of any kind; and besides, with what one spends [in Spain] in a single day, anyone can live well there for a week." Bargas stressed his own uncomfortable situation, "stripped of all favor, and having spent a great sum of maravedís to support himself without any hope of relief, while neglecting the chief aim of his business affairs in Cádiz."101

Bargas does not seem to have received anything he asked. It was said of him in early 1787 that "he has done other extravagant things and is living in Madrid with a brother of his named Asmed."102 In March of that year he asked the Spanish consul for a passport to Spain; as he took ship for Cádiz he was found

100 "Haze cinco meses que vino á vuestra corte, y sitios Reales a entablar barias pretensiones de su comercio con vuestros Ministros sin dexar de proponer pagaría los derechos correspondientes a vuestra Real Hazienda, y a quanto tiene solicitado, se le ha negado, tal bez por que no combendria a vuestro Real Herario: Pero haviendo sido todo con arreglo al comercio general de España, extraña que no se le haia atendido en parte de lo que [ha]impetrado; siendo asi que es publico y notorio que en su Pais en todos los Puertos, y pueblos, su Monarcha ha atendido, y favorece a todos los Españoles con particular distinción de las demas Naciones del Orbe, como es que a el Español que compra por carga de Trigo, paga quatro reales menos en fanega de derechos que las demas Naciones, y naturalmente, que lo sacan para otros Reynos: Si sacan Ganado Bacuno les haze igual grazia en que solo paguen sesenta reales por cabeza, lo que las demas Naciones y naturales que lo llevan para Gibraltar y otras Partes pagan cien reales vellón por cabeza; y a este tenor en los demas comestibles, y Generos que extraen de aquel Reyno se les hace a todo español, lo menos la tercera parte de Grazia que a toda Nacion": petition dated 3 November 1786, AHN, Estado, leg. 5803 .

101 The same petition of 3 November 1786, AHN, Estado, leg. 5803.

102 El Pardo to J.M. González Salmón, 16 January 1787, AHN, Estado, leg. 4319. 
to have hidden "inside a mattress up to forty short lengths of muslin," for which the governor of Tangier sent him to prison and fined him

one hundred duros to extricate himself and not have the matter come to the attention of His Moroccan Majesty. I tell Your Excellency this so you can form an idea of how they treat here those Moors who cross to Spain with the status of merchants. Of course any indulgence toward them or concealment [of their wrongs] is fruitless, because neither does the king of Morocco appreciate it nor are they themselves grateful for it: they are full of arrogance and passion and imagine or believe that just because they are Moors and subjects of His Moroccan Majesty everything is theirs by right.

The governor of Cádiz thought that "most of the Moors who cross to that city without any funds or reputation for business are the conduit that some merchants use for their contraband." ${ }^{103}$

Naturally enough, the Secretariat of State instructed the Spanish consul in Tangier to make Absalem return to Morocco at all costs: "I shall make sure to find a way to have Absalem Bargas return to that city [Tangier]."104

\subsubsection{Hamete Bargas (1784-1787)}

We know of Hamete, ${ }^{105}$ almost certainly a brother of Absalem Bargas, at least from 1784: in that year José Veciana, military governor of the coast of Granada, called him a man "of bad conduct, full of wiles and falsehoods."106 He traveled around Spain, especially to Málaga, Murcia, Alicante, and Madrid, between at least 1784 and 1787 , and was involved in robbing his fellow Moroccans. The Spanish consul in Tangier told the Secretary of State that he had been wanting to locate Hamete for a long time

\footnotetext{
103 “...Cien Duros por salir del asunto, y que no llegase á noticia de S.M.M. el asunto. Refiero a V.E. esto para que pueda formar una idea del modo que por acá se tratan a esos Moros que pasan a España con titulo de Comerciantes, y desde luego qualquiera indulgencia, ó disimulo que se tenga con ellos es infructuoso por que ny el rey de Marruecos lo aprecia, ny los mismos interesados son capaces de estimarlo, por que estan llenos de orgullo y entusiasmos que se figuran ó creen que por solo ser Moros, y súbditos de S.M. Marroqui, todo se les debe de derecho": J.M. González Salmón to Count Floridablanca, Tangier, 12 March 1787, AHN, Estado, leg. 4319.

104 Count Floridablanca to J.M. González Salmón, 13 April 1787. AHN, Estado, leg. 4319.

105 Also called Jamet, Jamete, and Ahmed Vargas.

106 José Veciana to Count Floridablanca, Málaga, 8 June 1784, AHN, Estado, leg. 4317.
} 
at the urging of the honored Minister effendi and the governor of this port, so that if he were found anywhere in the domains of the king our master he could be made to cross to Morocco willingly or by force, because in Madrid a Sherif who was in Spain with Bargas has testified against him. In La Alcantarilla, in Murcia, [Bargas] "disappeared" a number of oriental pearls so that the Sherif could never find them again or recover their value, and had to appeal to the Effendi; who, for this reason, urged me to bring him here, as Ben Abdelmelek has asked me several times to do by request of Bargas's own family. Knowing the Moor's bad conduct there, they want to have their eye on him before some serious loss should occur.

Since Vargas was then in Madrid, the consul asked that he be sent to Tangier under arrest to be handed over to the Moroccan authorities. It was important that he be arrested,

because if he is left at liberty he will certainly escape us, as he did two years ago in Alicante. Also at the urging of Governor Ben Abdelmelek, and when Don Antonio Oliver suggested that he should be brought here, he claimed that he was prepared to obey the order but asked for a few more days to complete some negotiations for saffron; and leaving the city on that pretext, he did not return to it. ${ }^{107}$

Indeed, in late 1786 and early 1787 Hamete was in Madrid, where he had gone to ask for an appointment as an interpreter in Málaga. The Secretariat of State

107 “...a Ynstancias del Ministro Effendy, y el Governador de Esta Plaza para que si se encontrase en algun parage de los Dominios del Rey Nuestro Señor, se le obligase pasar á Estos de Marruecos, por voluntad ó por fuerza, por haver representado contra él en esta Corte un Cherife que estubo en España en compañía del tal Bargas, y en la Alcantarilla de Murcia le desapareció este una cantidad de Perlas Orientales, de manera que el Cherife no se pudo hacer mas con ellas, ny con su importe, y se vió obligado a recurrir al Effendy, quien por este motivo me intereso para que lo hiciese benir, y Ben-Addelmeleck me lo á pedido varias vezes á instancia de la familia del mismo Bargas, que saviendo la mala conducta que guarda dicho Moro por allá, lo dessean tener a la vista antes que le suceda algun fracaso pezado. ... en arresto por que si se dexa libre, seguramente se nos escapa como hizo ahora dos años en Alicante que haviendolo pedido también por instancias de este Governador Ben Abdelmaleck, e intimándole Dn. Antonio Oliver, la precisión de benir a Esta, le dixo que estaba pronto a obedecer la orden, pero que teniendo una negociación de Azafran entre manos le urgia esperar algunos días mas, y haviendo salido con este pretexto de aquella Ciudad no volvió a ella": J.M. González Salmón to Count Floridablanca, 12 March 1787, AHN, Estado, leg. 4319. 
reported that he had left the capital for that city and warned the authorities in Málaga about him:

The Moroccan Moor Hamet Vargas has already left Madrid for Málaga to see if he can subsist in that town as an agent or interpreter for his countrymen. In general, Moors who have come here have not displayed the best behavior; rather they have given trouble through their scandalous dealings with women, their untrustworthiness in business, and their impertinent demands, which are usually unreasonable. Jamet Vargas has been one of these.

Still, following the policy of not dealing harshly with Moroccans out of consideration for their sultan, the Secretariat hoped that he might "change his ways and behave well." It recalled a decree of 31 October 1786 that forbade "any Moroccan or Barbary Moor to come to Madrid without prior permission or a passport issued by this Secretariat of State."108 Hamete, a "Moroccan Moor," also aspired to the post of interpreter in either Málaga or Cádiz:

For more than a year he has petitioned Your Excellency to be granted the post of interpreter of languages in the city of Cádiz or in Málaga, by virtue of being qualified to hold it, in particular with those of his nation, who would then have no reason to come to this Court nor any occasion to intrude on Your Excellency's attention. And since in all this time he has incurred too many expenses, he should withdraw to Cádiz.

In fact, however, Hamete Bargas cared more for acquiring privileges in trade with Morocco than for being an interpreter. He argued that if what he asked was impossible, he be recommended to the military governor of Cádiz "to consider him whenever goods from his country such as dates and slippers arrive, and look on him with fairness." 109 A marginal note on his petition reads, "Let

108 "Habia salido ya de Madrid para Malaga el Moro Marroqui Hamet Vargas con el objeto de ver si puede subsistir en ese Pueblo haciendo de agente ó interprete de sus paysanos. Generalmente los moros que han venido aquí no han tenido la mejor conducta antes bien han dado que hacer por su trato escandaloso con mugeres, poca fé en su trafico, y mucha importunidad en sus pretensiones por la mayor parte extravagantes. Jamet Vargas ha sido uno de estos": San Ildefonso to Marquis of Vallehermoso, 27 June 1787, AHN, Estado, legs. $5809-5810$.

109 "[H]ace mas de un año que tiene echa la pretensión con V.E. a fin de que se le conceda el empleo de Ynterprete de Lenguas en la Ciudad de Cadiz, ó en Malaga, en virtud de ser Persona apta para su desempeño, y en particular con los de su nación, quienes con este motivo no tendrán que venir a esta Corte, ni Lugar para molestar la atención de V.E.; y 
him go and let the governors of Cádiz and Málaga assist him so long as he conducts his countrymen's business well." Another note observes that Hamete Bargas "says that Your Excellency has offered to pay him a sum and give him a letter of recommendation for Málaga"; someone at the Secretariat, undoubtedly irritated, countered, "I have offered no such thing, just make sure he leaves." The final determination was that "Anduaga told him on 16 July 1787 that he could leave at once and that the letter would be sent directly to Málaga."110

\subsubsection{Hamet Federico (1784)}

Hamet appeared at the Spanish court to demand recompense for goods lost when a ship of his was wrecked in the Bay of Cádiz. An examination of the case "showed that his tale is highly exaggerated and even false in some points, so his wholly unfounded claim was denied." He than asked for a sum to pay for his journey home and was allowed 1,500 reales de vellón. In January 1787 he was still in Madrid. ${ }^{111}$

\subsubsection{Sarifey (1784)}

"The Moor Sarifey" was another man whom José Veciana named in 1784 as an individual of bad conduct who was always trying to deceive the Spanish authorities. We know nothing further about him, however. ${ }^{112}$

\subsubsection{Hach Hamed Erzini (1785)}

Hach Hamed Erzini, 113 "a most distinguished vassal of the Emperor of Morocco," reached Barcelona aboard an English galliot in late November 1785. He would have been one of the merchants with a strong interest in trading directly with Spanish ports in general and Barcelona in particular, as allowed in the Agreement of 1789 with Morocco. He arrived with "eight companions, merchants of that empire, and three slaves." He presented a written statement "expressing the many inconveniences he and his companions had suffered because of the narrowness of the vessel," and complained that other ports required only ten days of quarantine; considering his confinement a personal affront, he asked to be admitted at once or serve out the time in a warehouse on shore. The

habiéndosele originado en todo este tiempo demasiados gastos, le precisa retir[ar]se a dicho Cadiz": petition by Hamete Bargas, Madrid, 7 July 1787, AHN, Estado, legs. 58095810, Exp. 6.

110 In the file on Hamete Bargas, AHN, Estado, legs. 5809-5810, Exp. 6.

111 El Pardo to J.M. González Salmón, 16 January 1787, AHN, Estado, leg. 4319.

112 José Veciana to Count Floridablanca, Málaga, 8 June 1784, AHN, Estado, leg. 4317.

113 Also called Hamet Cresiny. 
Board of Health responded only to a second complaint, and used the occasion to speak of "the need to build at least a temporary lazzaretto in this port for such cases, which occur continually." It was impossible to ensure that "persons of distinction" and their goods could serve the quarantine in comfort. ${ }^{114}$

\subsubsection{Lanaya Bohalel (1785)}

In 1785 the Moroccan Lanaya Bohalel traveled to Cádiz, Madrid, and other cities on business for the Moroccan Makhzen. The sultan, who did not know where he was, asked the Spanish consul in Tangier to make him return: "Let him write to the governor of the place where the Moor Bohalel is, so that he be sent in one of the ships that comes to Casablanca; he owes money to his uncle in a matter that interests us, and when he has paid it he may go wherever he wishes."115

The consul asked the Secretary of State for information about Bohalel, "in case the Moroccan Moor Lanaya Bohalel is in Madrid, so that Your Excellency may order him to leave and come to these domains." He wrote to the governor of Cádiz as well, "so that for his part he can search for that Moor and force him to come here if he is in some city or location in the Kingdom of Andalusia."116 Almost two months later Bohalel was located in Gibraltar, and the sultan was informed in case he wished the English to surrender him. ${ }^{117}$

\subsubsection{Jamet Bigga (1786-1791)}

A Moroccan firmly established in Cádiz was Jamet Bigga, ${ }^{118}$ according to the testimony of the consul in Tangier in 1786:

They write me from Cádiz that the Moroccan Moor Jamet Biggá, who has been living in that city conducting business for some years, has gone to

114 The galliot, Los Tres Amigos under Captain Juan Piedra, sailed from Tetouan to Barcelona in late November 1785. In two written requests of 12 and 15 December Ramón Ayguals, a Barcelona merchant, asked the Board of Health to admit him to the port and let him serve his quarantine in a warehouse there; the second request was granted. Baron Serrahí to Junta de Sanidad de Barcelona, 15 December 1785, Ім нв, Fs. Serie I, leg. 16, fol. 86; Serie v, leg. 11, fols. 216-17, 20 December 1785. See Erzini, "British-Moroccan Relations," and "Hal yaslah li-taqansut?".

115 Translated letter from His Moroccan Majesty to J.M. González Salmón, 31 December 1785, AHN, Estado, leg. 4319.

116 J.M. González Salmón to Count Floridablanca, 3 January 1786. On 31 January the Secretariat was still urging the consul to locate Bohalel in view of the sultan's strong interest in him: AHN, Estado, leg. 4319.

117 J.M. González Salmón to Count Floridablanca, Darbeyda, 27 February 1786.

118 He appears as both Bigga and Biggá. 
Madrid in hopes of becoming an agent for Cherife, a Turk; it is to collect some small sacks of gold dust that a customs officer in Cádiz seized from Cherife last year. ... He is among the many Moors who fly to seek their fortunes in Europe. As far as I know his conduct is not bad, and in Cádiz he encountered two or three trading companies owned by Irishmen who have helped him and generated some [business]. ${ }^{119}$

But he warned that Bigga made excessive demands: "That Moor, in the requests he presents or has presented, exaggerates his rank as all of them usually do when they are in Spain; for there are few who do not try to make us believe that they have some commission from the sovereign himself, and that any special privilege they receive is much valued by their prince."120

Months later the Secretariat of State, denouncing the complicity of merchants from Cádiz and Morocco in smuggling, mentioned Bigga by name:

In effect, some have said that the Moor Jamet Bigga, the representative of the Turk Cherif of whom you spoke in your letter no. 135 of 6 October, has practiced certain deceptions in Cádiz. It is suspected that these included the gold dust that was confiscated and was ordered returned as a favor to the Turk (whom the Count of Expilly had warmly recommended for having served and accompanied him in his negotiations in Algiers); the two individuals are still quarreling about [the gold dust]. Bigga went to Madrid to ask for the gold dust, claiming it was his [crossed out: "with several extravagant claims that were denied"]. And while no special irregularity in his conduct was observed we understood that his petitions were supported by companies in Cádiz. ${ }^{121}$

119 "Me escriben de Cadiz, que el Moro Marroqui Jamet Biggá, que há algunos años reside en aquella Ciudad haciendo algun Comercio, ha pasado a esa Corte con motivo estar comisionado por un turco Cherife, para recoger algunos saquitos de polvo de oro que el año passado le quitó el Resguardo de las Puertas de Cadiz, al expresado Cherife.... [E]s un Moro de los muchos que bán volanderos á buscar su vida a Europa. Su conducta según tengo noticia, no es mala, y encontró en Cadiz, dos o tres Cassas de Comercio de Yrlandeses, que le hán dado la mano, y lo han fomentado algo": J.M. González Salmón to Count Floridablanca, Darbeyda, 6 October 1786, AHN, Estado, leg. 4319.

120 J.M. González Salmón to Count Floridablanca, Darbeyda, 6 October 1786, AHN, Estado, leg. 4319.

121 "En efecto no ha faltado quien diga que el moro Jamet Bigga comisionado del Cherife Turco de quien habló Vm. en su carta de 6 de octubre $\mathrm{N}^{\circ} 135$ ha tenido parte en algunas ocultaciones en Cadiz, y rezelado que fuesen de esta clase los polvos de oro que se confiscaron y que por favorecer al Turco (que havia recomendado mucho el Conde de Expilly por haberle servido y acompañado en sus negociaciones de Argel) se mandaron devolver, 
Bigga also sought a special authorization, "An exclusive privilege for himself and all the Moors of his nation to transfer freely in the Bay [of Cádiz] all the goods that arrive from the North and from Italy bound for Barbary, and those that leave there for Europe." While the consul was not sure that the petition was genuine, he informed the Secretariat of State because the matter seemed important. Indeed it was, because if accepted it would have been a heavy blow to activity in the port of Cádiz and to the Royal Treasury. ${ }^{122}$

Bigga was still in Cádiz in 179o, since he attended Muhammad b. Abd Allah al-Zuwayin (Essuin), Sultan Muhammad Ben Abdallah's envoy and brother-inlaw, during the latter's visit there; for those services the Spanish authorities paid him 3,530 reales de vellón. ${ }^{123}$ But he returned to Madrid and was there at the outbreak of the Spanish-Moroccan war of 1790-1791. The Moroccan ambassador, Ibn Utman, who was in Spain at the time, lamented that "the Moorish merchant Ahmet Begge" and "a companion" had been put in prison, where they had found "another six Moorish businessmen" in violation of the Treaty of 1767. Ibn Utman asked for freedom for all of them so they could collect their debts and attend to their affairs; he also hoped that they could remain in Cádiz during the conflict, or at least be granted passports to another country. ${ }^{124}$ Bigga had been arrested because of the justified mistrust he inspired in the Spanish authorities: the Spanish consul wrote from Cádiz that "we must be as wary of the Moroccan Moors in this city as of those over there." He was particular concerned about Jamet Bigga:

He communicates to his home country whatever he wants, whether it is true or not. Therefore, if these people are not to be forced out of the kingdom, they should go elsewhere in the interior so that none of them will be in the ports or their surroundings. In Bigga's case, not even sending him inland is prudent; his acquaintance among foreigners here helps him to continue his contacts, so it would be best to force him to leave. He will

y sobre los quales disputan todavía los dos sujetos. Bigga pasó a Madrid a solicitar se le entregasen dichos polvos alegando ser suyos [tachado: "con varias pretensiones extravagantes que le fueron negadas"] y aunque en su conducta no se advirtió cosa particular comprehendimos que estaba apoyado por casas de Cadiz para sus solicitudes": El Pardo to J.M. González Salmón, 16 January 1787, AHN, Estado, leg. 4319.

122 J.M. González Salmón to Count Floridablanca, Darbeyda, 6 October 1786, AHN, Estado, leg. 4319 .

123 J.M. González Salmón to Count Floridablanca, Cádiz, 10 and 13 July 179o, AHN, Estado, leg. 4313 .

124 Letter signed by Ibn Utman in Arabic and Spanish: "Ben Otoman" to Count Floridablanca, Ocaña, 18 September 1791, AHN, Estado, leg. 5818. 
probably never go to Morocco, but he can be made to travel to any other place he prefers so long as it is not one of our domains. ${ }^{125}$

The Secretariat of State promptly ordered Jamet Bigga and the other Moroccans to leave the kingdom. ${ }^{126}$

\subsubsection{Mohamed Benissa (1786)}

Mohamed Benissa ${ }^{127}$ sent a petition, dated in 1786 in Tangier, that described his services to Spain during the 1779-1783 war with Great Britain, particularly to the enclave of Melilla: "During the late war with England he had offered various services to the presidio of Melilla, supplying it with food, and consequently had lost two ships that the English burned. As a result he went to Algiers where he has an uncle, and recently crossed to Spain to request recompense or help with the cost of those services."

He had also provided aid to El Peñón de Alhucemas:

During the siege of Gibraltar I managed to supply the presidio of Alhucemas with everything they needed. Also, having heard that some Moors from that region wanted to deceive the Christians by luring them into the countryside on the pretext of selling them food but really to kill them, on learning of this I sailed in my launch to warn the fort. When the Moors heard the news they pursued me in order to kill me, and they burned my launch; therefore I beg Your Excellency to arrange that I be given something to aid me for these two actions [that I took] in favor of Spain and at the risk of my life. ${ }^{128}$

125 "[C]omunica a su tierra quanto quiere y se le antoja sea cierto, ó no, por lo que si no se piensa hacer salir á esta gente del Reyno, seria bueno fuesen a otros parages de lo interior para que no hubiese ninguno en los Puertos, ni sus inmediaciones, y a Bigga ni a tierra dentro será conducente embiarlo por que el mucho conocimiento que tiene aquí con los extranjeros le facilita la continuazion de la correspondencia por lo que no seria malo hacerle salir, bien que, probablemente nunca iría a Marruecos, pero se le puede obligar baya á otra qualesquiera parte que mas le acomode, con tal que no sea dominio nuestro": J.M. González Salmón to Count Floridablanca, 11 October 1791, AHN, Estado, leg. 4324.

126 San Lorenzo to J.M. González Salmón, 21 October 1791, AHN, Estado, leg. 4324. In 1800 the Bey of Mascara had a representative in Gibraltar: "our agent in Gibraltar named Ahmet, son of Muhamet Biggia." This may be our same man or a close relative: Duke of Frías and Marquis of Villena to Mariano Luis de Urquijo, Lisbon, 7 and 16 October 180o, AHN, Estado, leg. 5806.

127 He also appears as Mohamet Ben Yssa.

128 "[E]n el tiempo del sitio de Gibraltar e procurado proveer el presidio de Alucemas de todo lo que habían de menester y tambien que habiendo entendido que algunos moros de los de aquel Campo querían con cierta treta engañar a los cristianos haciéndolos benir á el 
The Secretariat of State investigated the matter but could find nothing "about this Moor and his services." It turned out that he had presented a similar petition, making the same claims, to the Secretariat of War, but it had been rejected based on information from "the Admiral of the Coast of Granada and the inspectors of Málaga and Alhucemas." Someone wrote on the edge of a page, "Let him be gone, for which he will be given four hundred reales."129

Benissa wrote from Cádiz again, however, on 26 June: he lamented "not knowing the Spanish language, and not being able to explain my petition face to face." Therefore he was writing "to tell you that I was unable to come earlier to pursue my request because Spain was at war with Algiers, at a time when I was in that city in flight from the violent men from Morocco of whom I wrote in my report to the Count of Floridablanca." After the peace treaty with Algiers he was allowed to travel to Spain to explain

my good offices to the Spaniards in Alhucemas: Sir, I have pursued this claim for nine months, spending money I do not have, paying ten reales a day for my lodging, and in short, I am now reduced to the sad state of having nothing left with which to pursue my claim. Nor can I pay my debts in a foreign land, and have no consolation but God's providence, the mercy of our king, and the generosity of Your Excellency.

In these straits he asked for funds to support himself, but when the reply came in November it was negative. Further, Consul González Salmón had orders tell the sultan to punish him if he should be forced to return to Morocco, ${ }^{130}$ but no

dicho Campo con pretesto de venderles Biberes y era para matarlos sabiéndolo yo pase con mi lancha a dar aviso al dho presidio de lo que noticiosos los Moros me persiguieron para matarme y me quemaron la lancha por lo que suplico a V.E. se sirba mandar se me de algo para poderme socorrer de estos dos echos a favor de España y a riesgo de mi vida": petition in the original Arabic and in Spanish, AHN, Estado, leg. 5803 .

129 "Because the Moor Mahamed Ben Ysa made the same appeal to the Secretariat of War [that is] in my charge as the one that Your Excellency sent me in your paper of the 26th of this month, the king asked for a report from the Marquis of Vallehermoso, Admiral of the Coast of Granada. He denied [the claim], citing reports on the matter by the inspectors of Málaga and Alhucemas": Pedro de Lerena to Count Floridablanca, Palacio, 30 December 1786, AHN, Estado, leg. 5803 .

130 “...[los] buenos oficios hechos a los Españoles en Alhucemas: nuebe meses Señor llevo en pretensión, gastando lo que no tengo, pagando diariamente 10 reales de posada y en una palabra, ya me veo reducido a la triste suerte de no tener con que seguir mi pretensión, ni poder pagar mis deudas, en tierra extraña, y sin tener mas consuelo que la providencia de Dios, la piedad en nuestro Rey y la clemencia de V.E.": from Cádiz, signed in Arabic, 26 June 1786. " "In view of all this, last 4 November His Majesty refused everything the said 
one actually knew where he was: the Secretariat could not say "if he will have gone by now."131

\subsubsection{Mohamed Barrada (1786-1787)}

Barrada was one of the merchants from Fez whose interest in trading directly with Spain was noted in the Hispano-Moroccan Agreement of 1780. The Diario de Madrid reported that he had a shop in the city in 1786, in Jacometrezo Street "next to the Plazuela de Santo Domingo." He sold the same goods as Aly Castillo and Absalem Crassy: slippers, kerchiefs and other cotton clothing, carpets, and dates. "The merchant is called Bar[r]ada and is a native of Fez."132 In 1787 he was one of three men accused of scandalous conduct with Spanish women and of having mocked the Sacrament:

Mohamed Barrada, Absalem el Crasi, and his brother Ajmed are still living in Madrid operating a shop that sells goods from that country [Morocco]. It has been necessary to warn them to avoid causing scandal with women and not to fail in respect for the Most Holy Sacrament when it is carried along the street where they live. They have been told either to withdraw at that moment or to act as the Christians do. ${ }^{133}$

\subsubsection{Jamet Shebany (1787)}

Shebany, a merchant from Tetouan, frequented Spanish ports: "he has made several voyages to Spain and went as far as Holland." He tried to avoid paying the required duties on imported goods and capital, and was forced to protest "the confiscation or retention in Sanlúcar de Barrameda of two thousand two

Mohamed demanded": Pedro de Lerena to Count Floridablanca, Palacio, 30 December 1786, AHN, Estado, leg. $5^{803}$.

131 Another document asserted that he had lost three boats while trying to aid Melilla: "he asks that we reimburse him for having supplied victuals to Melilla and having lost three boats during the last war." But the Ministry of War, "not in agreement with his explanation, denied his petition, as was confirmed later by this Secretariat": El Pardo to J.M. González Salmón, 16 January 1787, A HN, Estado, leg. 4319.

132 Diario de Madrid, 18 September 1786; cited in Sarasúa, Criados, 138.

133 "Todavia hay en Madrid actualmente un tal Mohamed Barrada, Absalem el Crasi y su hermano Ajmed con tienda de algunos generos de ese país, a quienes ha sido preciso amonestar eviten el escandalo que causaban con mujeres y el que han dado en faltar al respeto que se debe al Santisimo Sacramento quando pasa por la calle en que habitan, previniéndoles se retiren en aquel momento o que hagan lo que los demás Cristianos": El Pardo to J.M. González Salmón, 16 January 1787, AHN, Estado, leg. 4319. 
hundred fifty pesos fuertes found on the Moroccan Moor Jamet Shebany, without any paper or document that justified this amount."134

Shebany's brother ("who is [named] Talbe and is in the service of His Moroccan Majesty") learned of the situation, proof of the effective commercial and informational links between the shores of the Strait of Gibraltar. He wrote to both the governor and the Spanish consul in Tangier, insisting that "my brother is innocent in not having taken a document for that money, believing it was not needed. ... Not having had that paper was an innocent act on his part." The governor also conveyed to the consul the opinion of the "Qadi or chief judge of the city of Tetouan." The Moroccans hoped that Shebany would be pardoned and that his case would serve as an example to other tradesmen:

For this one time let the money be released; and if later some Moroccan vassal should remove funds from this kingdom and not declare them immediately on arrival in Spain with a paper from me or one of my confidants - [a policy] we have already decided and made public - then he will be the first to insist that the Moor who has done wrong be sent here, and he will punish him with his own hand to our satisfaction.

The consul asked that the governor's recommendation be followed, but observed that "if he had not intervened the Moor would be brought here under arrest, as is already the rule for all those who commit crimes in Spain."135 Ben Abdelmelek, Tangier's governor, defended Shebany, but the consul could promise only that "he will be set at liberty at once if Spain acknowledges that his not having declared it at the time was a case of sheer ignorance, without any other reservation. But otherwise we cannot ensure it, because it has already been decided to send here every Moroccan subject who is caught in a fraud."

Consul González Salmón, in possession of letters from the governor of Tangier and the merchant's brother, was confident that if the Secretary of State found Shebany to be a criminal he would hand him over in Tangier, in accordance with the peace treaty with Morocco:

134 J.M. González Salmón to Count Floridablanca, Tangier, 23 May 1787, A HN, Estado, leg. 4319.

135 “...que por esta vez se dexe libre el dinero y que si en lo sucesivo ocurriese que algun vasallo marroquí saque caudales de este Reyno, y no los presentase inmediatamente que llegue a España con un papel mio o de mis Confidentes como yá esta resulto y hecho publico, él será el primero que inste para que embie aquí al Moro que falte, y por su propia mano lo castigará a nuestra satisfacion": letter from Shebany's brother signed in Arabic, 1 May 1787; J.M. González Salmón to Count Floridablanca, Tangier, 23 May 1787, AHN, Estado, leg. 4319 . 
[If] he is found guilty Your Excellency should arrange for him to be sent to this [city] together with the money, all [to be placed] at the disposition of His Moroccan Majesty - who of course will feel no fondness for Shebany or for any other vassal of this monarch who commits fraud in Spain. I believe that forgiveness will harm the Royal Treasury, which should collect everything it finds that lacks a letter or other document, to remove suspicion or fear that it is involved in contraband. This example should be sufficient to frighten the Moors so they will not continue to abuse the favors and exceptions that are offered them there.

Governor Ben Abdelmelek should know that Moroccan tradesmen going to Spain needed a signed certificate from the consul declaring any money they carried, so that no one could plead ignorance:

Moroccan subjects who travel to or through Spain henceforth must carry a paper from me or one of my commissioners in a port of these domains, declaring the sums they bring so there can be no doubt that they took them out of this kingdom. Otherwise they might negotiate the money in clandestine fashion, whether it belongs to them or to others, when they move from one port to another in Spain. And if they are apprehended by customs officers and seek to use the excuse that they brought the money from here, where a document of permission is not usually carried (although some people request one), they also use this as a justification when they are asked for their papers.

The governor of Tangier approved the plan and hoped that it would be enforced. ${ }^{136}$

${ }_{13}$ " [S]i se halla culpado será bueno que V.E. disponga lo conveniente para que se remita á esta juntamente con el dinero todo a disposición de S. M. Marroqui, que desde luego no le quedará afición al mencionado Shebany ny a vasallo otro alguno de este Monarca hazer fraudes en España. Vien considero que esa providencia perjudica a la Rl. Hacienda por que deve tirar de todo lo que se encuentra sin despacho ú otro documentos que desvanezca la sospecha ó rezelo de que pase de contravando, pero este exemplar será suficiente para escarmentar a los Moros y que no abusen tanto de las condescendencias y disimulos que se les tiene por hallá. ... que los súbditos marroquíes que vayan en lo sucesivo a España ó de transito, hande llevar precisamente un papel mio o de los comisionados que tengo en los Puertos de estos Dominios, en que se declare los caudales que llevan para que no se dude después que los han sacado de este Reyno, por que de lo contrario les queda arbitrio de negociar el dinero por alto bien sea propio o ageno quando en España pasan de un Puerto á otro y si llegan a ser aprehendidos por los resguardos de Rentas buscan para libertarse el refugio de que lo han sacado de este Pais, y como no 


\subsubsection{Jamet el Bacal (1786-1787)}

Another petitioner with unreasonable demands was "the Moor Jamet El Bacal," a merchant from Tetouan. He interested the sultan's brother Muley Abdessalam in his affairs and had him write to the consul in Tangier on his behalf:

Sherif el Jach Jamet El Bacal has complained to us of having lost some money in your country, and he seeks no more than what is right: if through the courts he can obtain what he asks that will be satisfactory, and let him be given what is his. If he does not find justice with you he will remain as before, but if he receives justice under your law [do] not deny his petitions, and attend to our recommendation in this matter. ${ }^{137}$

The consul promised to look into the affair, but warned that

I greatly fear it will do no good, since he does not have justice on his side; since he did not insure his money no one will advance it to him, and he will have to accept his bad luck. ... [El Bacal] is asking to be reimbursed for 1,80o pesos fuertes that he claims to have lost in Cádiz aboard a Spanish ship that foundered in its bay; he bases this right on the fact that the Board of Health's felucca could have saved the money but refused to do it. This Moor speaks reckless nonsense as they all do when we do not agree with what they wish, though they know their petition is unfounded. ... [The petitioner] was kept dangling with false hopes until finally, unable to support himself, he returned to Cádiz and went on to Mogador to meet Prince Muley Absalem. I realize he will have told him unfavorable things about us (though this is no obstacle for us), because I think the prince will have listened to him just as Ben Abdelmelek did. [Ben Abdelmelek] tells me that we are wrong to allow Moors to visit Madrid without any errand or commission from their sovereign; I assured him that we have

es practica llevar Documento (aun que algunos lo piden) que lo acredite se disculpan también con esto mismo quando se les pregunta por los papeles": J.M. González Salmón to Count Floridablanca, Tangier, 11 May 1787. Shebany's brother's letter is dated 1 May 1787 and signed in Arabic: J.M. González Salmón to Count Floridablanca, Tangier, 23 May 1787, AHN, Estado, leg. 4319 .

137 "Cherife el Jach Jamet El Bacal, quien se nos a quejado de haber perdido algun Dinero en vuestra tierra, y el no busca otra cosa que lo que es regular; por justicia si puede lograr lo que pretende está bien, y que se le entregue lo que es suyo, y si el no alcanza de Vosotros justicia, quedará como antes, pero si por vuestra Ley tiene justicia, no negarle sus pretenciones, y atender en este asunto a nuestra recomendación": Muley Abdessalam to J.M. González Salmón, 19 October 1787, AHN, Estado, leg. 4319. 
taken steps to prevent it, but this leader wants us to expel those who are there now because he knows they go there to cause trouble. ${ }^{138}$

Everything indicates that our Jamet el Bacal was the same as "another called Hamet" who appeared in Madrid asking for restitution of the losses he suffered when a ship sank in the Bay of Cádiz. His tale "was found to be greatly exaggerated and even false in some details, so his wholly unfounded petition was denied." 139

\subsubsection{Absalem Karassi (1787)}

The Secretariat of State became aware of Absalem Karassi ${ }^{140}$ of Tetouan in 1781, when after his ship docked in Cádiz he was found to have lengths of muslin hidden under some mattresses; Spanish officials treated him leniently, allowing him to take the fabrics back to Tetouan. The consul was concerned that indulgence in such cases would only encourage merchants to attempt other frauds:

At first he showed such alarm and fear that the king of Morocco would find out that he persuaded several Moors to ask me not to make a complaint against him; and I did not make one because I had no official notice of the event and heard of it only from those who spoke to me on Crassy's behalf. After he was able to negotiate to have his muslins returned on condition he take them to Tetouan he grew bolder, and I do not doubt

138 "[D]esconfio mucho no tenga efecto por la falta de justicia que le asiste, pues no habiendo asegurado su dinero nadie se lo puede abonar, y deberá conformarse con su suerte ... [P]retende el reembolso de Mil ochocientos Pesos fuertes que dice se le perdieron en Cadiz a bordo de una Embarcacion Española que naufragó en dicha Bahia, fundando su derecho en que la falúa de Sanidad podía haber salvado este dinero, y que no lo quiso hacer. Este Moro desbarra y habla de disparates como todos ellos quando no se condesciende con sus desseos aun que conozcan su infundada pretencion. ... [S] le entretubo con buenas esperanzas, hasta que aburrido, y por falta de tener con que mantenerse, se volvió à Cadiz de donde pasó à Mogador, à encontrarse con dicho Principe Muley Absalem. Me hago cargo que le habra dado noticias poco favorables acia nosotros, aun que esto no nos embaraza nada, por que creo que el Principe lo habrá escuchado como Ben-Abdelmeleck quien me ha dicho que nosotros no hacemos bien con consentir pasen los Moros a Esa Corte quando no llevan Encargo ó Comision por parte de este Soberano; á lo que satisfize se han dado ya providencias para impedirlo, pero este Gefe dessea que se hagan salir à los que en la actualidad se hallen Allí, por que sabe que ban mas a que importunar": J.M. González Salmón to Count Floridablanca, Tangier, 19 November 1787, AHN, Estado, leg. 4319.

139 He was granted only 1,500 reales for his return trip to Morocco: El Pardo to J.M. González Salmón, 16 January 1788, AHN, Estado, leg. 4319.

140 Also called Absalem El Crassy, 
that given another occasion he will cheat. This would not happen if when they seized his smuggled goods they had sent him here with them for His Moroccan Majesty to administer justice. ${ }^{141}$

This must be the same Karassi from Tetouan whose shop in Jacometrezo Street in Madrid in 1786 carried "the same goods" as those of Mohamed Barrada and Aly Castillo. ${ }^{142}$ The next year he was admonished by Spanish authorities together with Mohamed Barrada and his brother Ahmed, all three for behaving scandalously with women and mocking the Holy Sacrament. ${ }^{143}$

\subsubsection{Ahmed Karassi (1787)}

Ahmed Karassi ${ }^{144}$ was also in Spain, almost certainly accompanying or subordinate to his brother Absalem. We know only that he was one of the three Moroccans accused in 1787 of scandalous behavior with women and mockery of the procession of the Holy Sacrament when it passed along Jacometrezo, "the street where they live."145

\subsubsection{A merchant from Fez Who Died in Málaga (1787)}

Other incidents that may or may not be related to commercial activity might have harmed relations between Spain and Morocco if they had not been dealt with promptly. In May 1787 the Secretary of State asked the Spanish consul in Tangier about the incident of "a Moor who was disinterred in Málaga."146 The consul consulted the governor of Tangier, who confirmed that in the Andalusian city "a Moroccan Moor, a native of Fez," had died, and after his burial in a place indicated by the government his corpse had been dug up at night and thrown into a corral. The governor had received a complaint from the

141 "[A]l principio estubo con tanto miedo, y recelo de que lo supiese el Rey de Marruecos, que interezó a varios Moros, para que yo no diesse quexa alguna contra él; efectivamente no la di por que no tube de este passage ninguna noticia de oficio, y solo lo supe por los mismos que me hablaron interviniendo por el Crassy, y como después pudo este negociar el que se le volviesen sus Musolinas con la condición de traerlas a Tetuan, cobró animo, y no dudo que si se le proporciona otra occasión haga fraudes, lo que no sucedería si quando le agarraron los generos de contravando lo huviesen enviado aquí con ellos, para que S.M. Marroqui lo juzgase": J.M. González Salmón to Count Floridablanca, Tangier, 12 March 1787, AHN, Estado, leg. 4319.

142 Diario de Madrid, 18 September 1786. Cited in Sarasúa, Criados, 138.

143 El Pardo to J.M. González Salmón, 16 January 1787, A HN, Estado, leg. 4319.

144 Also known as Ajmed el Crassi.

145 El Pardo to J.M. González Salmón, 16 January 1787, AHN, Estado, leg. 4319.

146 Aranjuez, Count Floridablanca to J.M. González Salmón, 15 May 1787, AHN, Estado, leg. 4319. 
deceased's brother and had convinced him to discuss the matter in Tangier before appealing to the sultan. He hoped to dissuade him from "expressing his complaint, because it will certainly make a bad impression on His Moroccan Majesty, not so much because the Moor was killed but because they disinterred him and threw his body into a filthy place." The consul doubted that all the details of the story were true, but promised to write to the Admiral of the Coast of Granada asking for information: if the tale were confirmed they must determine "who the guilty parties were, both in the Moor's death and in his disinterment; they will be punished as their crime requires and if they are apprehended we will not show them the slightest mercy." The governor of Tangier awaited the consul's conclusions, and the latter approved his caution. ${ }^{147}$

Having received information from Málaga, the consul provided a new version of the events: the Moroccan "was wounded and then cured, but after many days fell victim to malignant tertian fevers from which he died. He was buried by other Moors in the place designated for it, where Protestants are also buried." His brother claimed that his body had been exhumed and profaned by unknown persons, but the Spanish consul hastened to tell the governor of Tangier that the report was untrue. Armed with letters from the governor of Málaga, he told Tangier's governor that he possessed

authentic justifying documents that reveal as imaginary and false everything that the brother of the dead Moor had told the governor. For although it is true that he was wounded and cured ... On examining the spot where the cadaver was buried it was found to bear not the least trace of any person's having been there.

The governor of Tangier accepted the explanation, which demonstrated "the imposture and falsehood they have accumulated against us." ${ }^{148}$ The important point here is that both governor and consul agreed in giving the lie to the false accusation, to keep it from harming the relations between the two countries:

147 J.M. González Salmón to Count Floridablanca, Tangier, 3 May 1787, AHN, Estado, leg. 4319.

148 “...con documentos autenticos y justificativos, que dán por supuesto y falso todo quanto á este Governador le avia dicho el hermano del Moro Muerto; por que aunque fue cierto lo hirieron, curó y después de muchos días le acometieron unas Tercianas malignas de que falleció y se le dio Sepultura por otros Moros en el sitio señalado para ello, y donde se entierra a los Protestantes; que examinado el lugar donde se puso el Cadaver se encontró sin el menor indicio de que persona alguna huviese llegado a él": J.M. González Salmón to Count Floridablanca, Tangier, 30 June 1787, AHN, Estado, leg. 4319. 
A brother of the dead man who is now in Tetouan wishes to raise a complaint to His Moroccan Majesty about the whole affair. But he has written to him to desist and come to Tangier to speak to me before going to the Court. Ben Abdelmelek also told me that he was acting on the hope that once he was here he could be dissuaded from making that complaint, which would surely make a poor impression on His Moroccan Majesty not so much for having killed the Moor as for having disinterred him and thrown his corpse in a filthy place.

The governor trusted the consul's account:

He gave me to understand that he had no doubt of our honesty and fairness, but that the king his master would still be much displeased if he heard that after one of his vassals died in Spain he was thrown into a corral. And if the deceased's brother should come here, at least we can detain him while we obtain some report of what really happened. And I find the governor's decision a very prudent and correct one. ${ }^{149}$

The problem of Muslim burials in Spain - where by the late eighteenth century Muslims could live in total freedom - remained unresolved and would be deferred to a later date.

\subsubsection{Hamet Almanzor (1789)}

In 1789 Hamet Almanzor and Hamant Sidon, two "Moroccan Moors," filed a petition after having had 37,0oo pesos fuertes confiscated in Cádiz: "they say they had sent them from Tetouan in a Spanish ship so that from Cádiz they could

149 "Que un hermano del muerto que en el dia se halla en Tetuan, quiere ir a dar quexa a S.M.M. de todo el echo; pero que él le ha escrito suspenda este paso, y que benga a Tanger para hablar conmigo antes de pasar a la Corte. Assi mismo me manifestó BenAbdelmeleck que hacía esto con la idea de ver si teniéndolo aquí, se le puede disuadir baya a dar dicha quexa por que seguramente hará mala impresión en S.M.M., no tanto por haver matado al Moro, como por que lo hayan desenterrado, y tirado su cadáver en un sitio inmundo. ... Me dio a entender que no lo dudaba de nuestra rectitud, y justicia, pero que esto no quita para que desagrade mucho al Rey su Amo si oye que despues de haver muerto en España a un vassayo suyo, lo tiraron al muladar, y que viniendo aquí el hermano del Defunto, por lo menos se podrá entretener hasta que yo tenga algun informe de lo que en realidad haya ocurrido, y pareciéndome mui prudente y acertada la determinación de dicho Governador": J.M. González Salmón to Count Floridablanca, Tangier, 3 May 1787, AHN, Estado, leg. 4319. 
send this money to the north." The local office of the Treasury investigated and found that

the result is very different from what the Moors claim in their petition: there are reasons to suspect that the money did not come from Tetouan and may belong to some merchants from Cádiz. These, by using the Moors and abusing the privilege and tolerance we offer them, have fraudulently attempted to export that silver to the North.

Silver coins and perhaps gold ones also circulated in mysterious ways that were difficult to track and account for. Officials must be vigilant about the "sinister reports" that Moroccans would provide in their native land, and the vice consul in Tangier was instructed to inform the sultan himself or his minister about any cases. But there was no doubt that some customs officers were complicit, in light of

the carelessness on the part of officials in Cádiz who at the moment of landing, and when the Moors deposited the boxes or chests of money in their customs house, did not demand the permissions or authorizations that I have ordered given to all those who take sums out of ports in Morocco for Spain and other destinations, if they have to touch at our ports.

The Moroccans Almanzor and Sidon, who were in Madrid at the time, were ordered to pursue the matter in Cádiz, and the Moroccan ambassador took an interest in the case. The two were found guilty but were allowed to "give themselves up to the Moroccans or whomever is responsible for them, with the requirement that they leave Cádiz and all other towns in His Majesty's domains without ever being allowed to reenter them. Otherwise the established punishment will be applied to them."150

150 “...[el] resultado hasta ahora es muy diverso de lo que los Moros representan en su memorial por lo que hay razones para sospechar que el tal dinero no ha venido de Tetuan, y si que pertenezca a algunos Comerciantes de Cadiz, que valiéndose de los Moros, y estos abusando de la condescendencias y tolerancias que se tiene con ellos, han intentado hazer fraudulentamente la exportación de dicha Plata para el Norte... descuido que ha habido de parte del resguardo de Cadiz, en no haber pedido a los Moros al tiempo de desembarcar, y depositar en aquella Aduana las Cajas o Baules con el dinero, las Guias o Despachos que tengo mandado se den a todos lo que por los Puertos de Marruecos saquen caudales para España u otros destinos, si tienen que tocar en nuestros Puertos." There were actually three Moroccans implicated in the affair: "Morocco, 1789, Cádiz, 179o, Madrid, 1791. On the smuggling and extraction of 36,933 pesos fuertes perpetrated on 1 October 1789 by the Moroccan Moors Benamar, Almancor and Amas Sidon." The case was 
This order does not seem to have been carried out: at the end of the century someone named Hamet Almanzor appeared in Cádiz once again and played an important role. We will return to him in the Epilogue.

\subsubsection{Hamant Sidon and Benamar (1789)}

As we saw in the previous section, the Moroccans Hamant Sidon and Benamar were implicated in 1789 , together with Hamet Almanzor, in an illegal attempt to export currency. Benamar also drew the attention of Spanish authorities, probably for circulating negative information together with Jamet Bigga. In 1791 the Secretary of State ordered the Spanish consul to expel him from Cádiz "and from the kingdom."151

\subsubsection{Abdilfadil Yallul (1791)}

Yallul, from Tetouan, found himself in trouble in Cádiz in 1791 after the goods he was transporting were confiscated: he "crossed to Cádiz with some goods that were withheld by Customs as items that had lately been forbidden, although the petitioner was unaware of the prohibition." He offered to pay the customs duties in order to recover them. ${ }^{152}$

\subsubsection{Hach Abafidil Benchulona (1791)}

He was recommended by the sultan's secretary and ambassador Ibn Utman, who asked the governor of Ceuta, Luis Urbina, in 1791 if his friend Benchulona could be conveyed to Algeciras and then helped to travel to Cádiz by land. The Moroccan was granted thirty-seven pesos for his expenses and three horses to transport him and his goods. ${ }^{153}$

\subsubsection{Hamet Monfux (1791-1792)}

When war broke out between Spain and Morocco in 1791, according to the Peace Treaty of 1767 citizens of each country residing in the other had to return home within six months. Such must have been the situation of "the Moor Hamet Monfux, resident in this city" of Granada: around September 1791 he petitioned the king of Spain to let him remain until he had collected a series

still active in 1791: J.M. González Salmón to Count Floridablanca, Madrid, 23 December 1789; Count of Lerena to Count Floridablanca, Palacio, 17 February 1791, AHN, Estado, legs. 5809-5810.

151 San Lorenzo to J.M. González Salmón, 21 October 1791, AHN, Estado, leg. 4324.

152 Report from the Cádiz customs house, 15 July 1791, AHN, Estado, legs. 5809-5810.

153 Arribas Palau, "La estancia en España de Muhammad Ibn Utman," 136. 
of debts owed to him, after which he would leave the country. ${ }^{154}$ The debts originated in his "business of buying pearls for export, and also other types of clothing which he resells at retail to poor people for weekly payments; these people would suffer harm if he pressed them for the [full] amounts they owe him." Besides, he had a "suit pending in the Royal Chancellery over the transfer of the shop where he lives." ${ }^{\text {155 }}$ The authorities in Granada found it reasonable "to allow him a period of two months to put his affairs in final order and prepare his departure,"156 and the king concurred. ${ }^{157}$ The President of the Council of Castile conveyed these decisions to Granada, reminding officials there that Monfux had "appealed to the king asking that his departure not be hastened until he could collect several amounts that he is owed"; the king had granted him "a reasonable delay for making these collections, telling officers of the law to encourage them so that once the allotted time has passed this Moor shall leave Spain." But in case "his remaining should cause any inconvenience," the king instructed that he "depart leaving a list of his debtors, so that efforts can be made to make them pay and send the amount collected to him wherever he may indicate." 158

\subsubsection{Sidi Mahamet Mekani (1793-1797)}

"The Moor Mekani,"159 who had a relationship with the Spanish commercial house of Benito Patrón and partners, appears in the sources in 1783: the business specialized in importing wheat from Darbeyda (Casablanca). The French vice consul in Rabat, Monsieur Mure, told the Spanish consul that Mekani had lived in Cádiz: "as you have known for a long time, he crossed to Cádiz with his son to settle his accounts with Señor Patrón."160 On his return to Morocco he

154 Count of Cifuentes, President of the Council of Castile, to Marquis of Contreras, 12 September 1791, Archivo de la Real Chancillería de Granada, Caja 4.405.

155 Felipe Gil de Taboada, judge of the military base, to Benito Puente, Granada, 26 September 1791, Archivo de la Real Chancillería de Granada, Caja 4.405.

156 He made his petition through a written report: Count of Cifuentes to Benito Puente, Madrid, 21 October 1791, Archivo de la Real Chancillería de Granada, Caja 4.405.

157 Count of Cañadas (in the absence of the President of the Council of Castile) to Benito Puente, 26 October 1791, Archivo de la Real Chancillería de Granada, Caja 4.405.

158 Count of Cifuentes to Benito Puente, Madrid, 17 January 1792, Archivo de la Real Chancillería de Granada, Caja 4.405.

159 Also called Mecany.

160 M. Mure, French vice consul in Rabat, to J.M. González Salmón, Salé, 18 June 1793, AHN, Estado, leg. 433 o. 
claimed to have been well received, especially by the Spanish consul who was in Cádiz at the time. ${ }^{161}$

In January 1797 Mohamet Bargas, the governor of Rabat, complained to the Spanish consul ("our friend") that Mekany had been improperly detained in Cádiz by the Holy Office and accused of being a Jew:

News has reached me of what happened there to the Moor Mecany, whom they put in prison without any motive. This is irregular, and besides they have supposed he is a Jew; you know his father and that they come from one of the principal families of Rabat, so the one who arrested him should have informed himself first among the Christians and Moors, to make sure of the truth and act justly.

He reminded the consul that, by the Peace Treaty of 1767 , should "one of your nation commit any crime [in Morocco] we would either ignore it if it is minor or hand him over to your consul for punishment according to the laws of Spain." But Spain did not reciprocate, because "some of your judges act and proceed with Moors as they do with Spaniards, which is in opposition to the Peace Treaty." He resisted his first impulse to report the case to Sultan Muley Sliman before learning the consul's version of events, "since you have dealt with the affairs of this kingdom for many years, no one knows better the rules that prevail in it." He could understand that the consul might not wish to speak in Mekany's favor, but not that he should fail to report the incident. He also wrote to the governor of Cádiz, asking him "to punish the one who told the false tale that supposed Mecany to be a Jew; for if that person feels no consequence he will do something worse another day." Should Mekany die in prison "we would be much displeased with you, and if you do not remedy these offenses I cannot remain silent about them: I will write to Muley Soliman so that he can inform King Charles." ${ }^{\prime 62}$

161 Letter from Sidi El Hadgi Abdalá Bargas, governor of Rabat, to Antonio González Salmón, AHN, Estado, leg. 4330.

162 "[M]e ha llegado la noticia de lo que ha acaezido ahí con el Moro Mecany que lo pusieron en la Carzel sin motivo alguno, y esto está fuera de regla, además de que le han supuesto que es Judio: Vosotros conocéis a su Padre y que proceden de una de las Casas mas principales de Rebat, y asi devio el que lo arrestó informarse primero de los cristianos y moros para certificarse de la verdad con lo que procedería según justicia." He added in a postscript: "We have always been friends and all the Moors of Rabat remember and recollect your generosity in arranging to send us wheat when we were in great need": Hach Mohamet Bargas to J.M. González Salmón, 16 January 1797, AHN, Estado, leg. 4338. 
The consul duly passed on to the Secretary of State the complaint about the Moroccan's arrest. ${ }^{163} \mathrm{He}$ thought it essential, to avoid "motives of mutual resentment," that Spain's justice system not violate terms of the Peace Treaty in its dealings with Moroccans; the treaty stipulated

that a Spaniard who commits any offense in [Morocco] be handed over to his consul [struck out: "Commissioner"] so that, in trying him according to our laws, he receive the proper punishment and be sent to Spain; up to now the Moors have followed this scrupulously, and we should reciprocate as good harmony requires.

He recommended ordering the immediate arrest of the Moroccan who had borne false witness against Mekany, and that the individual be remanded to the Spanish consul to be sent on to the sultan and punished according to local law. That would eliminate any cause for complaint, and "keep Moroccan vassals more controlled, for without doubt they fear this outcome more than any punishment they might receive in Spain; and at the same time we would be observing what is agreed on this point [in the treaty]."

This policy brought other benefits as well:

The Moors deal with our citizens in their country according to their laws, by virtue of which we do the same here with them according to ours (which are most benign and fair). Spaniards have suffered the cruel [punishments] that they inevitably impose, for just a small incident of smuggling causes delinquents to have their hands cut off; and very slight faults are in proportion, since raising one's hand against a Muslim is punished with hundreds of strokes that leave [men] crippled. Further, our good reputation would be much weakened if those citizens saw a Spaniard punished with the measures established for themselves. ${ }^{164}$

163 He struck out from the draft the phrase "on account of false information that he was a Hebrew."

164 “...que el Español que cometiere qualesquiera delito en el se entregase a su Consul [tachado: Comisionado], afin de que juzgándolo según nuestras Leyes se le impusiera el castigo correspondiente, dirigiéndolo a España, lo que hasta ahora han observado escrupulosamente los Moros, a que debemos corresponder, según lo exigen la buena armonía .... [L]os Moros tratan a nuestros Nacionales en su Pais con arreglo a sus Leyes, en virtud de que lo executamos nosotros aquí con ellos, conforme a las nuestras (que son muy benignas, y equitativas) sufrían los Españoles las crueles que irremisiblemente imponen, pues por solo un chico contrabando tiene la pena de cortar las manos a los delinquentes; y a proporción las mas ligeras faltas, como levantar la mano a un Musulman lo castigarían con centenares de palos, que los dexase inhábiles. A que se agrega que nro. buen concepto 
As a consequence of all this a royal decree proclaimed "that Moroccan criminals be remanded for judgment to their country with the brief about their case, the Commissioner being charged with forwarding it to their government."165 The consul informed the governor of Rabat, Ibn Utman, and Tahir Fenis of "the treatment that in the future should be given to Moroccans who commit a crime." He hoped that this would satisfy them and they would "set aside the resentment caused them by the imprisonment of the Moor Mecany in this [city]. By this means we shall ensure that proceedings against delinquent Moors in Spain will correspond to those practiced in that kingdom against our citizens who commit some excess." ${ }^{166}$

\subsubsection{Taib Ben Cachet (1793)}

In September 1793 the governor of Tangier asked the Spanish consul general in the city, who was in Cádiz at the time, to protect Taib Ben Cachet, whom he was sending to Cádiz to buy for the sultan an assortment of fine textiles and linens worth 3,500 pesos fuertes. 167

Because Ben Cachet had enjoyed the consul's confidence, ${ }^{168}$ the latter could inform the Secretary of State that Ben Cachet's secret mission from Tangier's governor was to try to send Muley Sliman more than 36,000 pesos fuertes that had been seized from Moroccan merchants in previous years. He made clear

se debilitaría notablemente si viesen aquellos Naturales castigar á un Español con las penas establecidas a ellos": J.M. González Salmón to the Prince of Peace [Manuel Godoy], Cádiz, 17 February 1797, AHN, Estado, leg. 4338.

165 Prince of Peace to J.M. González Salmón, Aranjuez, 3 March 1797, AHN, Estado, leg. 4338.

166 It was considered essential to inform the Moroccan authorities, especially Ibn Utman, of everything, since that information "will cause great satisfaction to that magnate. For he is persuaded by proof that his concerns merit Your Excellency's attention, and lends himself with energy to whatever is recommended as just and fair": J.M. González Salmón to the Prince of Peace, Cádiz, 10 and 21 March 1797. The Court responded that "efforts are being made to find and punish the offender, and the Commissioner [of the Holy Office] has been reproved, as the letter from the talbe requested": Prince of Peace to J.M. González Salmón, Aranjuez, 11 March 1797, AHN, Estado, leg. 4338.

167 Letter from Hach Hamet Dlimi in Arabic and Spanish translation: "The king my master ordered me to buy four lengths of fine cloth, twenty of the coarser variety [estopilla], and some of medium grade [creas]. Therefore I wish to send to that [city] Sid Taib Ben-Cachet so that someone you trust can guide him in performing this errand - that is, someone connected with Don Alexandro Risso - until all is accomplished." He offered to pay the price in Cádiz or to the Spanish vice consul in Tangier, and added that he had told Ben Cachet verbally "certain things for him to tell you in private": Hach Hamet Dlimi to J.M. González Salmón, Tangier, 1 September 1793, AHN, Estado, leg. 433 O.

168 J.M. González Salmón to the Duke of La Alcudia, 6 and 27 September 1793, AHN, Estado, leg. 433 o. 
that the sum "did not belong to the Moors, nor did they have any role except as an instrument for committing the fraud, and therefore nothing could be done in the matter."

González Salmón thought it wiser to send the sultan the fabrics as a gift, "since I believe this is his true desire.... The prince will be very grateful for this small attention and will punish the wrongdoers severely."169 The governor of Tangier expressed his appreciation for the gesture. ${ }^{170}$

\subsubsection{Jamete Vinjut (1793-1794)}

In April 1794 Abdrajaman Vinjut, "a Moroccan Moor and native of Tetouan," sent two petitions from Málaga, one to the king and one to the Secretary of State. The first identified him as a brother of Jamete: "In the city of Granada, a year ago, a Moor named Jamete Vinjut died; [he was] a brother of the petitioner, settled in that city with a shop [that sold] a variety of goods." ${ }^{171}$ He had made a will with the scribe Juan Polayno stating that Miguel Acosta would receive "whatever small or great estate he had; to whom he left sixteen thousand reales in cash, seven packets of emeralds, some furniture, and used clothing." Before his death he had also "agreed with another Moor to whom he transferred his shop; his goods had a value of fourteen thousand reales and they drew up a receipt for it to protect them both." After the decease, however, the Moor who had kept the shop "broke the agreement they had made" and "gave whatever goods he wished to the said Miguel Acosta." Abdrajaman claimed that Acosta "should not have received any item at all from that Moor because they had made their agreement, as is proved by the paper they drew up" and by the will. Later Acosta and the scribe Polayno decided that the former would take "a certain sum so that Acosta could receive the transferred goods," an action that showed "the twisted reasoning of Acosta and the scribe to obscure the truth: they believed that the deceased, being a Moor, would have no heir, so

169 J. M. González Salmón to Duke of La Alcudia, 6 and 27 September 1793. His proposal was approved on 4 October 1793 .

170 Hach Ahmad al-Dalimi (who also appears as Amet Delimine and Hamet Dlemi) showed the consul "his gratitude for the fine treatment he received" and wrote him of "the constant friendship I have always had with you and with which you have treated me in that [city]": Hach Ahmad al-Dalimi to J.M. González Salmón, Tangier, 2 May 1793. J. M. González Salmón to Abdrajaman Ben-Nasar, governor of Safi, Cádiz, 3 Many 1793. J.M. González Salmón to Duke of La Alcudia, Cádiz, 10 May 1793, AHN, Estado, leg. 4330. See also Arribas Palau, "Ahmad al-Dalimi, gobernador de Tánger."

171 Both documents are dated 26 April 1794 and signed in Málaga in Arabic and Latin letters: AHN, Estado, leg. 5802 . 
their deceits would not come to light and all would remain between the two of them."

The scribe, "in fees for [drawing up] his dead brother's will alone, robbed him of seven thousand reales." Abdrajaman felt that as a foreigner he was defenseless: "though the petitioner is a Moor and in a foreign land, powerful Sir, he can find no reason or motive for [the scribe's] having taken the seven thousand reales." He claimed that "various persons in Granada owed sums to his brother, as the account book shows," those debts adding up to six thousand reales; but the scribe had appropriated them also. Abdrajaman had traveled to Granada "as the heir, to take possession; and seeing that all that was done was unjust he reported it to the chief magistrate, who gave him no help." The Treaty of 1767 had made provision for the inheritances of Moors who died in Spain, and when the authorities in Granada ignored his demands he had filed his suit, as other Moroccans had done in similar circumstances. On his return to Tetouan he "informed his king of how that scribe in Granada had acted"; the sultan then wrote to the governor of Tetouan asking that he inform the Spanish consul general in Tangier. The consul, in turn, contacted the Admiral of Málaga requesting that the affair be brought before the president of the Chancellery of Granada, and Abdrajaman returned to that city to reopen his case. He still felt helpless, however: "Moors do not understand lawsuits nor does their religion allow for them, especially when there is no legitimate motive for them."

Abdrajaman pointed out that his brother had had no debts and yet he had been able to collect only eight thousand reales, while the scribe had received the other seven thousand plus six thousand collected from Jamete's debtors. Legally, then, the surviving brother should receive fourteen thousand reales. He asked the Chancellery and Admiralty of Málaga to force Juan Polayno to surrender the fourteen thousand and to collect "the fee for the testament" that his brother had drawn up. ${ }^{172}$ His petition to the Secretary of State again stressed his helplessness: "finding myself in a strange land I am moved to implore Your Excellency's pity so that you may respond to the entreaties of your humble servant." Someone wrote on the margin "Recommend this to the Admiral," but we do not know the outcome of the case. ${ }^{173}$

172 The sums mentioned do not balance perfectly.

173 Abdrajaman declared his faith in the Spanish judicial system: "The justice that assists me." Abdrajaman Vinjut to Duke of La Alcudia, Málaga, 26 April 1794, AHN, Estado, leg. 5802. 


\subsubsection{Sidi Cassen Reisi (1793)}

In August 1793 a Spanish xebec from Ceuta captured the brigantine Annuntiatina with seventeen Frenchmen aboard, and it was judged a legitimate prize. It carried

twelve Moors and one Hebrew with a Moroccan ensign and passport, and a certificate sealed and signed in Tangier by Consul Don Antonio Salmón, declaring the ship to belong to a Moor from Salé who is a friend of Spain. Therefore he requests assistance for the vessel, but in spite of these circumstances it is detained because it carries seventeen Frenchmen, two hidden cannons, and the flag of the [French] Assembly. ${ }^{174}$

Several Moroccan governors and merchants claimed that the brigantine flew their country's flag and was called the Saida, that its captain was Mohamed Ben Embark, and that the Frenchmen were merely passengers. They brought their protests before the consul and vice consul, and less directly to the Secretary of State; their action shows that the two sides enjoyed good relations, and that the Moroccans expected Spanish agents to intervene and resolve the issue in a way favorable to them. The governor of Tetouan, Ibn Utman, complained that the Moroccan flag had not been respected: "he was much surprised that the flag of these domains is not properly honored, which is a breach on our [Spain's] part." The problem was grave, for the brigantine could show passports issued by the sultan and the European consuls in Tangier together with "documents signed by the scribes of Sale that proved the legitimacy of its purchase by the Moors." The vice consul assured Ibn Utman that the Moroccan flag was scrupulously respected, and promised him to apply "the full justice that follows from the harmony existing between the two nations."175 The governor of Rabat protested the Spanish decision to consider the Frenchmen crew members rather than passengers:

174 “...doze Moros, y un Hebreo con Vandera y Pasaporte de Marruecos, y una certificación sellada, y firmada en Tanger por el consul dn. Antonio Salmon, en que acredita ser dicho Buque de un Moro de Salé con quien tiene amistad España, por lo que encarga se le auxilie, y sin embargo de dichas qualidades está detenido por traer á su bordo diez y siete franceses, dos cañones ocultos, la Vandera de la Asamblea": Marquis of Casa-Tilly to J.M. González Salmón, Isla de León, 21 August 1793, AHN, Estado, leg. 4330.

175 A. González Salmón to J.M. González Salmón, Tangier, 21 August 1793, AHN, Estado, leg. 433 o. 
I assure you that I have felt this action keenly, and for the moment do not wish to recount it to the king my master so as not to alter the good friendship that he professes toward your monarch. You well know that our sovereign (may God exalt him) loves yours very much; and the best proof of his esteem is the permission he has granted to Spaniards, excluding other Christian nations, to ship wheat out of these ports at a time when that commodity is still very expensive in our country and the Muslims complain of these exports. As for me, I am desirous that the king my master and yours may always continue to be in harmony.

The governor reminded the Spaniard that Moroccan merchants had set sail "after you had assured us that they could go wherever they wished without interference from anyone," and added that the captain's documents were in order. He was therefore surprised by the Spanish action:

Since you are our best neighbors, and therefore the most beloved by our sovereign, why have you proceeded in this way against us, destroying all the ties that bind us and the assurances you have given us? Why are you committing such an irregular act toward our prince just for the sake of a few passengers who are protected by his flag?...As for us, because we have embarked passengers under our sacred flag you arrest and detain our captain, ship, and cargo, which belong to Moroccan merchants as proved by the documents that are in possession of the Moorish tradesman who is aboard our ship. You are making our captain waste his time, and you do all this at a time when other nations respect us; and it is customary that if passengers sail under the flag of a sovereign they shall in no way be molested.

He noted that he had provided a safe-conduct to the brigantine's French passengers to allow them to return home, and begged that the Spanish court be asked to release "without delay" the ship, its cargo, and "the passengers, since they are under the protection of our flag." He did not wish the matter to reach the ears of the sultan, who would take it very badly: "what you have done is improper, so I have concealed it from him that he may continue to feel the same sentiments of friendship toward you that you know he professes." The governor of Rabat also wrote to the consul asking him to mediate: "I will be grateful if you do all in your power to have orders issued as soon as possible to release Captain Ben-Embark."176

${ }_{176}$ "Os aseguro que he sentido sobremanera éste proceder, de él que por ahora no quiero hacer sabedor al Rey mi Amo, por no alterar la buena amistad que profesa a vuestro 
The consul informed the Secretary of State that the brigantine had belonged to the French consul in Morocco, M. Mure, but that he had sold it at the outbreak of his country's war with Spain in 1793

to a merchant of that city who, together with others, loaded it with different goods from that country to ship to Livorno. As for the seventeen Frenchmen aboard, I am convinced that they are the same ones belonging to its former crew, together with that of a tartane of the same nation that Mure also sold to the Moroccans. It sails from one port to another on that coast, and since these men have no money for returning to their country they have taken advantage of the occasion and the protection of the neutral Moroccan flag to go to Livorno and proceed from there to their homeland. ${ }^{177}$

Monarca, y bien saveis que nuestro Soberano (a quien Dios exalte) ama mucho al vuestro, y la mayor prueva de la estimación que le tiene, es el permiso que ha concedido á los Españoles, con exclusión de las demás Naciones Cristianas, para que extraigan trigo por estos Puertos en un tiempo en que dicho renglón se mantiene aún muy caro en éste Pais, y que los Musulmanes se quexan de dicha extracción, quando por mi parte estoy deseando que el Rey mi Amo y el Vuestro sigan siempre con buena harmonia... [V]osotros siendo nuestros mejores vecinos, y por lo mismo los mas bien quistos de nuestro Soberano, ¿como se ha podido efectuar de parte vuestra ácia nosotros semejante procedimiento, que destruye todos los vínculos que nos unen, y las Seguridades que nos haveis dado? ¿Que hagáis una cosa tan irregular para con nuestro Principe por solo el motivo de unos pasajeros que estan baxo la protección de su bandera?....Y Nosotros porque hemos embarcado Pasageros baxo el Sagrado de nuestra bandera, apresais y deteneis á nuestro arraez, buque y cargamento que es de cuenta de Mercaderes Moros según lo acreditan los Documentos que paran en poder del Comerciante Moro que se halla á bordo de nuestra dicha embarcación, haceis perder tiempo á nuestro arraez, y todo esto lo executais en una época en que las demás Naciones nos respetan, y que es costumbre de que si algunos Pasageros se embarcan baxo la Bandera de un Soberano, de ningun modo son inquietados": Sidi El Hach Abdallah Bargas, governor of Rabat, to A. González Salmón, August 1793, A HN, Estado, leg. 433०.

“...a un Comerciante Moro de aquella Ciudad, y éste, en compañía de otros, la ha cargado de varios efectos de aquel Pais para Liorna. Los diez y siete Franceses, que conduce, me persuado sean los mismos de su antigua tripulación con la de una Tartana de la propia Nacion, que también vendió dicho Mure á los Marroquíes, y hace viajes de un Puerto á otro en aquella Costa, y que no teniendo estos hombres proporción de regresar á su Pais, hayan aprovechado de la coyuntura y seguridad de la Bandera Neutral Marroqui con destino á Liorna, para desde allí transferirse á su Patria." The Spanish consul, who believed that Mure was sincere, considered it best to treat his French counterpart tactfully because his aversion to the French Republic (proclaimed in 1792) made him sympathetic to Spanish policies: J.M. González Salmón to Duke of La Alcudia, Cádiz, 23 August 1793. The seventeen Frenchmen were sailors from four French ships who had been sold 
He added that the matter must be dealt with so as not to prejudice relations between Muley Sliman and "important men of his faction," who "must find this highly irregular, since they had been solemnly promised that their mercantile flag would in no way be interfered with by our warships. Their distrust of us will only grow greater." He warned of "the damage that can ensue in our political arrangements with the Moors, if they do not see their brigantine released as soon as may be." He would be informing the sultan of the "reason that has been given for this detention, so as to dispel any bad impression the prince may have received from this event and so that he will have no motive for mistrusting our conduct and good faith."178

The Secretariat of State took at least some of the consul's pleas to heart: it ordered the Moroccans on board to be set at liberty while retaining the ship, its cargo, and the Frenchmen. ${ }^{179}$

More complications ensued when the Moroccans claimed that the brigantine's crewmen were mistreated in Ceuta, something that the city's governor denied. The vice consul, concerned for "the chief object of maintaining good harmony between the two nations," thought that the brigantine's documents should have sufficed to prove that it had been sold "to some Moors." He worried about how the detained Moroccans might react because of "the character of these people, who do not reflect on whether actions are proper if these inconvenience them in any way." "Ill-intentioned Moors" would exploit the incident, as would "Europeans [who] would find an excellent motive to make us uncomfortable on the pretext that we ignored the Moroccan flag, and would impugn our good faith." He thought it essential to inform Muley Sliman that "we have proceeded justly"; if this were done quickly "it would give him one more proof of our desire to strengthen our mutual friendship, acknowledging in his favor what public law granted to us; adding that the poor conduct of the captain gave reason to reprove him so as to avoid other cases of the same kind."180

The Spanish consul, for his part, told the Secretary of State "how resentful the Moors are because we do not immediately return or release their ship"; he feared that in retaliation they might interrupt grain exports just when Spain

to the Moroccans. J.M. González Salmón to Duke of La Alcudia, Cádiz, 17 September 1793. Mure to J.M. González Salmón, Salé, 14 September 1793, AHN, Estado, leg. 433O.

${ }_{17}$ The consul reported on "the feelings that this event have begun to arouse in those people," claiming that it was best to placate them "so that they do not grow inflamed": J.M. González Salmón to Duke of La Alcudia, Cádiz, 23 August 1793, A HN, Estado, leg. 433 o.

179 Duke of La Alcudia to J.M. González Salmón, 3 September 1793, AHN, Estado, leg. 433 O.

180 A. González Salmón to J.M. González Salmón, Tangier, 27 August 1793. Notice to the governor of Ceuta on 23 August 1793, A HN, Estado, leg. 4330. 
urgently needed them. He suggested that, "whether or not the detention is legitimate and well founded," the brigantine should be turned over "because the Moors will never accept that it was a legal prize, even if it were justified to declare it so. And if they note any reluctance on our part and grow displeased to the point of blocking our ships and funds, the value of the Moroccan brigantine's cargo would not make up for [the loss]."181

The king was persuaded to order the release of the ship and the Moroccans, while continuing to detain the French until it could be determined "what kind of men they are and the purpose of their voyage." His decision was to be conveyed to Muley Sliman "and the appropriate leaders," as "clear proof of the mutual regard and sincere friendship that the king still feels for him."182 González Salmón notified Muley Sliman that "in accordance with the customs and rights of war that ship should be considered a legitimate prize, because among the men who make up its complement there is a larger number aboard from an enemy nation (that is, the French) than of Moors." ${ }^{183}$ The measure was also announced to the governors of Rabat, Tangier, and Tetouan "and to the other leaders and magnates" to remove "any bad impression that this event may have made on them."184

Nonetheless, the Minister of the Treasury in Ceuta claimed to possess proof that the sale of the brigantine to the Moroccans had been "false and concealed." 185 The king therefore ordered the ship, cargo, and Frenchmen to remain under arrest, though he approved the Moroccans' release "as a sign of our particular regard and friendship." The consul had to write to Muley Sliman once more:

The sale to the Moors is false, and arranged by the French themselves in concert with their friends; there is not the least doubt of this in view of

181 He also warned that delay in making a decision "can harm us greatly with every passing day": J.M. González Salmón to Duke of La Alcudia, Cádiz, 30 August 1793, AHN, Estado, leg. 4330.

182 Duke of La Alcudia to J.M. González Salmón, San Ildefonso, 3 September 1793, AHN, Estado, leg. 4330.

183 Spain wished to give a proof of its "considerate gesture" to show "how great and true is [its] mutual regard and sincere friendship" with the sultan: J.M. González Salmón to Muley Sliman, Cádiz, 10 September 1793, AHn, Estado, leg. 4330.

184 J.M. González Salmón to Duke of La Alcudia, Cádiz, 13 September 1793, AHN, Estado, leg. 433 .

185 The Secretary of State advised the consul: "once again: first look over the documents and arguments he presents, so that we may make no mistake": Duke of La Alcudia to J.M. González Salmón, San Ildefonso, 9 September 1793. J.M. González Salmón to Duke of La Alcudia, Cádiz, 17 September 1793, AHN, Estado, leg. 433O. 
the documents, papers, and effects found on board, and the statements of the Moors and Frenchmen of the crew themselves. ... Some Moors played a part in this affair, lending their names to disguise the truth of the matter. They deserve punishment because they have deceived both Your Highness and us: Your Highness because, on the pretext of having bought the ship, they received a passport from you; and us because while the ship and its cargo were French, as is now confirmed, they were favoring the interests of [the French] by means of dissimulation and pretense. ${ }^{186}$

Naturally, the "Moorish businessmen" from Rabat who claimed to own the brigantine and its cargo were very angry. They were Sidi El Hach Abdallah Bargas (Rabat's governor), his son El Hach el Miki Bargas, Sidi Cassen Reisi, Sidi Taib Reisi (the purser, nephew of the former), Sidi Lhage Hamet Feniche, and Captain Mohamet Ben Embark. ${ }^{187}$ The governor claimed that the Frenchmen were not crew members but passengers, and therefore under the protection of the Moroccan flag; the captain could not leave Ceuta without them "because it would much offend our prince, since these men are under our flag." 188 The consul retorted that the documents seized, and the crew's statements, proved that the brigantine and its cargo were French, and that the Frenchmen could not be released "while we are in a state of war with them." He reminded the governor that freeing the Moroccans had been a demonstration of friendship. ${ }^{189}$

186 "La] venta á los Moros es falsa y supuesta por los mismos Franceses de concierto con sus amigos; no dexando la menor duda de todo esto los Documentos, Papeles y efectos encontrados á bordo, y las declaraciones de los propios Moros y Franceses de su tripulación. ... Algunos Moros ... han intervenido en éste asunto prestando sus nombres para disimular la verdad del hecho, son dignos de castigo, porque han engañado á V.A. y á Nosotros; á V.A. porque con el pretexto de que havian comprado la Embarcacion, alcanzaron el Pasaporte que les dió; y á Nosotros, porque siendo propiamente dicho Buque y carga de Franceses, como ahora se ha verificado, resulta que favorecían los intereses de estos por los medios de disimulación y fingimiento": J.M. González Salmón to Muley Sliman, Cádiz, 16 September 1793, AHN, Estado, leg. 433 .

187 Each one owned one-sixth of the ship, which they had bought in 1793 for six thousand pesos fuertes. The buyers pledged to take the French crews of four ships sold to the Moroccans to Genoa or Livorno. There was a certificate from the Chancellery of the French consulate general in Salé (6 June 1793) and another that recorded that the cargo (wool, hides, gum Arabic, and tragacanth valued at 8,366 pesos fuertes) had been sold to Cassen Reisi, Taib Reissi and another two Moroccans: Governor of Rabat to J.M. González Salmón, 28 September 1793, AHN, Estado, leg. 4331.

188 Governor of Rabat to J.M. González Salmón, 14 September 1793, AHN, Estado, leg. 4330.

189 J.M. González Salmón to Hach Hamet Bargas, Cádiz, 16 September 1793; also J.M. González Salmón to Duke of La Alcudia, Cádiz, 24 September 1793, AHN, Estado, leg. 433 O. 
Ibn Utman, the governor of Tetouan, was also concerned, although it is not clear whether he was personally implicated in the brigantine and its cargo. He demanded of "our esteemed and beloved friend Manuel Salmón" the liberation of the Frenchmen "who are under the flag of the king my master." He hoped to strengthen the friendship between the two monarchies, since it was unfortunate

to have any quarrel as we are beginning to renew our friendship. We continue in the same good harmony as always, and we hope with God's help that it will be greater than before; we trust that this time you will release the French, and that if another law should arise in relation to affairs of the sea you will inform us so that we can all obey it. ${ }^{190}$

The consul informed the Secretary of State that Ibn Utman "insist[ed] strongly" on the need to release the French. He would let the sultan know why Spain did not believe "the complaints that may reach him from the Moors about this affair."191

The brigantine's owners managed to attract Sultan Muley Sliman's interest to the case, though the sultan adopted a milder tone than theirs: he wrote to the vice-consul, "If you are at peace with us, you should not treat us worse than you do the Christian nations who are at peace with you." If the capture had been legal, he continued, both the Moroccans and the French should suffer the same fate; therefore he could not accept the release only of the former. Treating the two groups alike would be to the Spaniards' advantage: "Your generosity will be lauded if you put them all at liberty, or give all of them no cause for complaint against you." If Spain acted in accordance with the law of the sea that all nations accepted, it would have to mete out "severe" punishment to the captain "who exposed those Christians to danger and implicated us in an illicit act."192

\footnotetext{
190 “...que haya disgusto en los principios de una renovación de amistad. Nosotros seguimos con la acostumbrada buena harmonia que siempre, y esperamos en Dios será todavía mas que la antigua, confiando en que por ésta vez soltareis á los Franceses, y si hubiese otra nueva Ley por lo que hace á la Mar, nos la comunicareis para que la observemos todos": Ibn Utman to J.M. González Salmón, Tetouan, 17 September 1793, AHN, Estado, leg. 433 o.

191 J.M. González Salmón to Duke of La Alcudia, Cádiz, 27 September and 11 October 1793. The vice consul wrote to the sultan that the merchants had "deceived him with the documents that they presented to obtain his passport": A. González Salmón to J.M. González Salmón, Tangier, 24 September 1793, AHN, Estado, leg. 433O.

192 Muley Sliman to A. González Salmón, 20 September 1793, AHN, Estado, leg. 4331.
} 
Antonio González Salmón, in his reply to the sultan, assured him that Spain was treating the Moroccans well:

It observes with the inhabitants [of Morocco] the same that it practices with friendly Christian nations. But in the case of this ship it has been even more considerate, ordering it released with its Moors and its cargo, even though by the general laws of the sea [the ship] was subject to being declared a legitimate prize by the mere fact that its crew included a majority of subjects of an enemy power.

Further, the French knew that "they were in danger of being seized by vessels of any power that is at war with France"; the captain had been warned both by him and by the consuls of Portugal and Venice that the Frenchmen could not ship as sailors. According to the "Public Law of War" the ship could legally be captured if more than one-third of its crewmen were subjects of an enemy nation. ${ }^{193}$

In another letter the governor of Rabat argued that the captain could not depart and leave the Frenchmen under arrest, "because he would fear displeasing our king under whose flag he had embarked them." The governor did not trust the documentary proofs found in Ceuta, claiming that the purser had been carrying "all the papers and documents concerning the purchase of the ship and its cargo issued by our public scribes and by the Qadi." ${ }^{194} \mathrm{He}$ could not understand why those documents were not accepted, unless Ceuta's "pirates and thieves" (a phrase crossed out in the translation) "wanted to take possession of Muslim ships." He assumed that the king of Spain had made his decision after having been "grossly deceived" (another crossed-out phrase), and added: "You know that I try by all means to maintain the good friendship that prevails between our king and yours, and between their respective subjects, so that harmony and proper proceedings may always be present between them."

193 “[O]bserva con sus habitantes lo mismo que practica con las demás Naciones Christianas amigas, sino que en el caso ocurrido con dicho buque ha tenido mas consideración mandando ponerlo en libertad con los Moros y su carga, no obstante que por las leyes generales del Mar estaba sugeto á que se declarase por buena presa por solo el hecho de ir tripulado con mayor numero de vasallos de Potencia enemiga": A. González Salmón to Muley Sliman, 25 September 1793. A. González Salmón to J.M. González Salmón, Tangier, 1 October 1793, AHN, Estado, leg. 4331.

194 Governor of Rabat to J.M. González Salmón, 28 September 1793, AHN, Estado, leg. 4331. 
You offend me by not placing any faith in my words, instead believing some highway robbers who set themselves up as judges of their own case, producing testimony forged for their own convenience. ... My probity is known to every Moor in the country, and these men trust whatever I tell them about you and your friendship. ... My conduct and intervention established the friendly ties that exist between my master and yours; for when my master was here in Rabat I spoke much to him about this, and convinced him to allow you to export wheat from all his ports on favorable terms, something that no other nation has been able to achieve. ${ }^{195}$

He insisted that Spain had promised to protect Moroccan ships:

The Moors did not decide to buy the ship commanded by Captain BenEmbark until after I had assured them of the friendship I thought you professed toward us, trusting in what you had written to us: that our ships could sail anywhere without anyone hindering them. On this promise the friendship between us was based, and in return you have impugned my word before the king my master and all the Moors, so that in the future they will no longer believe what I tell them in your favor. ... You who are our best and closest neighbors have treated us thus.

He had persuaded the brigantine's Moroccan owners not to go to the sultan, because their sovereign "would regret it very much, and that could alter the harmony that exists between ourselves and you: the ship belongs to his subjects and flies his flag, so I thought it best that they not complain to him." For his part, he "aspire[d] only to maintain the good understanding and friendship between the two nations," hoping that "you [Spaniards] will do the same, and make ever stronger the friendship between the two kings and their vassals." And he ended with a heartfelt lament: "We have always taken you for reasonable people of noble sentiments, and for this reason we wonder greatly that

195 "Me haceis la afrenta de no prestar fé alguna á mis palabras, y creeis mas bien a uno[s] salteadores que se establecen Jueces en su propia causa produciendo testimonios fraguados por su propia conveniencia". También se daba a valer: "mi probidad, que es notoria á todos los Moros del Pais, y estos se fian de quanto les aseguro de Vosotros y de vuestra amistad. ... [P]or mi conducto é intervención se han establecido los enlazes amistosos que subsisten entre mi Amo y el vuestro; porque quando mi amo se hallaba en ésta de Rebat le hablé mucho sobre esto, y logré que permitiera la Extraccion de trigo á favor vuestro en todos sus Puertos, sin que otra alguna Nacion haya podido obtener semejante gracia": Governor of Rabat to J.M. González Salmón, 28 September 1793, AHN, Estado, leg. 4331. 
you can have done such a thing - something that no one in this world would have done, so as to avoid unpleasantness." 196

In a later missive the governor complained that the brigantine's crew were being poorly treated,

suffering many inconveniences and receiving justice from no one. If you wished to act honestly you would have the vessel, its captain, and its crew taken to Cádiz so that this matter could be litigated and settled there, so that the Moors might rest, for in Ceuta they are dying of hunger and are being mistreated in word and deed, which is unjust and goes against good friendship.... [The Spanish] in Ceuta wish to keep our money, our goods, and our ship; they are welcome to them, but let them at least give us back our Moors.

He reproached González Salmón saying, "How little have you kept your promises!", and ended by begging for the Moroccans' liberty once again, though in fact they had been detained only briefly after the brigantine had first been seized. ${ }^{197}$

The consul explained to his superior that he believed the brigantine and its cargo to be Moroccan property. The governor of Rabat had challenged him: if the authorities found "any item or merchandise that is not a product of the Kingdom of Morocco or does not belong to the individuals named in the

196 " $[\mathrm{L}]$ os Moros no se determinaron á comprar la Embarcacion que manda el Arraez BenEmbark, sino después de haverles yo asegurado de la amistad que crei nos profesabais, fiado en lo que nos escribisteis de que nuestros Buques podían navegar en todas partes sin que nadie los inquietara, sobre cuya seguridad se ha cimentado la amistad entre Nosotros, y en pago de todo esto havéis desacreditado mi palabra acerca del Rey mi Amo y de todos los Moros, quienes en lo succesivo no creeran ya lo que les pueda decir en vuestro abono. ... [V] osotros que sois nuestros mejores y mas inmediatos vecinos, haveis procedido asi con Nosotros.... Siempre os hemos tenido por Gente sensata y de sentimientos nobles; por lo mismo extrañamos sobre manera que haya podido suceder semejante cosa de parte vuestra, cosa que nadie en este mundo hubiera hecho para no dar margen á disgustos": Governor of Rabat to J.M. González Salmón, 28 September 1793, AHN, Estado, leg. 4331 .

197 “...sufriendo muchas incomodidades sin que nadie les haga justicia; Si Vosotros quisieseis obrar según la verdad, mandaríais llevar á Cadiz la Embarcacion, su Arraez y Tripulacion, para que en dicho Cadiz se litigue y averigüe este particular, a fin que los Moros descansen, pues en Ceuta se mueren de hambre, y los maltratan en obras y palabras, lo que no es justo, ni se conforma con la buena amistad. ... Los de Ceuta quieren quedarse con nuestro dinero, generos y Buque, háganlo en hora buena, pero siquiera que nos debuelban los Moros. ... iy que poco haveis cumplido vuestras promesas!": Hadgi Abdalá Bargas to J.M. González Salmón, 18 November 1793, AHN, Estado, leg. 5803. 
documents," he would withdraw his complaint. Otherwise Spain should pay reparations for the damages incurred by the ship's detention, calculated by the governor at twenty-five percent of the value of the wool. The consul therefore advised that, to avoid further dispute, "even if the Moors did not claim the brigantine and its cargo (to which they have a right, according to their documents), it would behoove us to make Prince Muley Soliman a gift of the ship and its contents, while explaining to him the well-founded motives that led us to proceed as we have done." Handing over the ship and cargo as a special favor would demonstrate the Spanish king's generosity, while explaining the reasons for the seizure might "disabuse them of any notion that we proceeded out of self-interest and merely to exercise our power." If justice were seen to be done, Muley Sliman would be satisfied. The owners of the brigantine, however, "will never accept that there was justification for declaring the ship a legitimate prize, no matter how sound our reasons may be."198

The letters back and forth continued. Ibn Utman wrote again to the Spanish consul claiming that the accusation that the brigantine and its cargo were French had originated with both the captain of the xebec that had seized it and the Ministry of the Treasury of Ceuta, both of whom had a direct interest in the prize. He asked to examine the report drawn up in Ceuta: "If you would allow me to see these statements [by the passengers and crew], we could settle the matter at once.... [It is] a universal custom that an enemy flying the flag of a friendly nation should be free, this being the general law of all nations." Even if the ship were declared a legal prize and ceded to the Moors, claimed Ibn Utman, "you still have much scope for doing good; and the friendship between my king and yours is much greater than all this. We too have done far more that what the law prescribes in favor of the king of Spain. ... If between ourselves and you, our neighbors, such a firm friendship reigns, you should not give so much importance to a petty affair like this."

Ibn Utman insisted that Muley Sliman objected to the arrest of the French "because to him, it is a great offence committed against his flag. ... Do not continue this embarrassment for my master, because it would be a very bad thing. ... The immunity given by the flag to the Frenchmen in that ship" had to be respected. ${ }^{199}$ The governor also wrote directly to the Secretary of State,

198 In the consul's opinion, "It would be useful if we returned everything." In a sentence later crossed out he claimed that the return would be beneficial because of "the positive effects that it can produce, not only on Muley Sliman but on all the Moors of his states in general": J.M. González Salmón to Duke of La Alcudia, 18 October 1793, AHN, Estado, leg. 4331.

199 Ibn Utman, governor of Tetouan, to J.M. González Salmón, Tetouan, 1 October 1793. Draft letter from J.M. González Salmon to Ben Otoman, Cádiz, 17 October 1793. In November the governor insisted that swift action be taken about the brigantine, "suggesting that its 
"though in a different style," suggesting that "if there were no other solution," at least the Frenchmen who had traveled under Muley Sliman's flag should be set free. The Duke of La Alcudia reported to the consul that the king favored freeing the Frenchmen in spite of "the strange conduct of those people [the Moroccans]."200

Mure, the French consul, also wrote to insist that the Frenchmen aboard the brigantine were passengers. Its Moroccan owners, he said, "are extremely angry; I myself have had to absorb much invective and insults hurled against the people of Ceuta." The owners threatened to send a delegate to the sultan asking for "vengeance for such an obvious theft," and there was talk of detaining Spanish ships in Moroccan ports. Mure claimed that he and the qadi had calmed the waters by arguing that if an injustice had been done, it was because "the king of Spain has been fooled by the people of Ceuta," but that when the king saw the documents of the ship's purchase he would certainly see justice done. ${ }^{201}$

The captain and co-owner of the brigantine, Mohamed Ben Embark, also wrote to the Spanish consul, whom he considered his only advocate in Spain: "Our interests are in your hands, since we know no one else to [attend to] them in Spain, but I have not yet heard from you although you know I am your good friend and cannot forget the good you have done me. I hope that you will strive to let me be successful in my affairs."

He complained of the harsh treatment meted out to his crew by the "Christians of Ceuta," who

have done us great harm, scarcely even giving us water. I went to the governor's house to tell him that this port was very bad and that he should send us to Algeciras or Málaga or some other port in Spain; and he replied

delay only causes complaints and disagreements between the two nations":J.M. González Salmón to Duke of La Alcudia, 29 November 1793, AHN, Estado, leg. 4335.

200 Duke of La Alcudia to J.M. González Salmón, San Lorenzo de El Escorial, 11 October 1793, AHN, Estado, leg. 4335.

201 Mure claimed to have owned the brigantine's cargo but to have sold it to Moroccans at the outbreak of the war between Spain and France. He had asked the captain to take on as passengers the crews of the four French ships sold to the Moroccans, confident that they would meet no difficulties while under the neutral Moroccan flag. He believed it impossible that any documents could prove the ship and its cargo to be French: "the Moors' ownership is sufficiently established by the papers they hold, and there should be no more doubt about it”: Mure to J.M. González Salmón, Salé, 5 October 1793, AHN, Estado, leg. 5803. The consul considered Mure "a man of his word": J.M. González Salmón to Duke of La Alcudia, Cádiz, 18 October 1793, AHN, Estado, leg. 4335. 
that he had no such order, so we should await the [order by] post; and from one post to the next they continue to hold us. The only three cables we have are in the water and totally spoiled, having been in use for three months; and I tell you, so you will be aware, that these Christians of Ceuta do not treat us by the laws of war or of peace, as you know better than anyone. They have also taken away our passport and our papers, even the ones certified by the consuls - even private letters from the pilgrims who were going to Alexandria and then to Mecca, as well as a small gold bar. When we ask for the papers, they reply that they are in Madrid. We are asking that our ship be taken to a safe harbor; if it is a true prize let them keep it, and if not, let them return it, but they want neither one thing nor the other. You should ask men of the sea if this ship can ride at anchor in this port for three months without damage. ${ }^{202}$

In another letter Ben Embark complained again about ill treatment in Ceuta: "These Christians do not act justly, for they commit fraud from the beginning and wish only to deprive us and our children of life. We are at your disposal and in your charge; you are the consul and protector of the Moors; you know us, and we know you." 203

In an effort to recover the brigantine, the cargo, and the French crew, Cassen Reisi, ${ }^{204}$ one of its co-owners and "a principal magnate of Rabat," arrived in Cádiz empowered to negotiate "to defend his rights." ${ }^{205} \mathrm{He}$ wished to proceed to the Spanish court but was dissuaded: he should not "doubt our fairness,

202 "[N]os han hecho muchos perjuicios, pues hasta el agua nos la escasean: fui á Casa del Governador, le dixe que éste Puerto era muy malo, y que nos mandara á Algeciras, ó Málaga, u otro Puerto de España; y respondió que no tenia orden, y que esperáramos el Correo, y de correo en correo, nos va deteniendo. Los tres cables únicos que tenemos están en el agua y enteramente hechados a perder pues hace tres meses que trabajan, y yo os lo aviso para que lo sepáis: y estos Cristianos de Ceuta ni nos tratan sobre el pié de guerra, ni de paz y vos lo saveis mejor que ninguno, igualmente nos han quitado nuestro Pasaporte y papeles, incluso en estos las patentes de los Consules, y hasta las cartas particulares de los Peregrinos que iban á Alexandria para la Meca, y también una barrita de oro; quando les pedimos dichos papeles responden que están en Madrid. Lo que Nosotros pedimos es que pongan en Puerto seguro á nuestra Embarcacion, que si fuere buena presa se queden con ella, y si mala, que nos la devuelvan, y no quieren ni uno, ni otro, pero vos podeis preguntar a gente de Mar si este Buque puede quedar, sin perjuicio, fondeado tres meses en éste Puerto": Mohamed Ben Embark to J.M. González Salmón, Ceuta, 4 November 1793, AHN, Estado, leg. 5803 .

203 Ben Embark to J.M. González Salmón, Ceuta, 29 December 1793, A HN, Estado, leg. 5803.

204 He is also called Casem Reissy and, in French sources, Cassen Riya.

205 J.M. González Salmón to Duke of La Alcudia, 18 October 1793, AHN, Estado, leg. 4331. According to the letter Cassen Reisi bore from the French consul M. Mure in Salé, "he 
friendship, and good faith, nor that the king our master will attend to them." He appealed, unsuccessfully, for the brigantine and its whole file created in Ceuta to be taken to Cádiz to be examined by the Naval Court at the Isla de León. He also testified that when the ship's owners learned of its seizure they had tried to appropriate some Spanish ships, but that one co-owner, the governor of Rabat, had convinced them not to. ${ }^{206}$

From Cádiz Reisi wrote to the consul lamenting that "I am sick in bed and write you this letter because I cannot go to see you." He was worried that the brigantine might be lost "because winter has begun and that port is very badly [equipped]," and complained further that "a Christian from Ceuta stabbed my black slave, who is there with my nephew, and the wound leaves little hope that he will live." Since he considered the capture illegitimate he was requesting compensation for the expenses incurred for the vessel and its crew. He therefore asked González Salmón to

attend to my affairs so that in some way or another the ship can leave that port. For this I wish you to write to your king about the expenses and damage the Moors have suffered since being detained there, for these are much increased; and I also wish you to request an indemnity, because the Moors have no one but you to advocate for them. ${ }^{207}$

Cassem Reisi heard from his nephew in Ceuta, Taib Reisi, with the news that Ibn Utman, normally favorable to the Spanish, had told Ben Embark during the latter's eighteen days in Tetouan that Morocco might declare war on Spain: "If they do not do you justice we will make war as surely as there is a God; yet he will be glad if things go well to everyone's satisfaction. Still, he has an order from the king his master to go to war over this matter and to seize the consul no matter what might ensue."

According to Taib, Ben Embark was glad that war had not broken out, believing that "Consul Salmón is working with the greatest zeal to have the court

himself could purchase the ship and its cargo and argue for their rights": 5 October 1793, AHN, Estado, leg. 5803 .

206 J.M. González Salmón to Duke of La Alcudia, 18 October 1793, AHN, Estado, leg. 5803.

207 "[Que] miréis por mis asuntos para que de una manera ú otra salga del referido Puerto la Embarcacion por lo qual quiero que escrivais á vuestro Rey por el Gasto y perjuicios que han tenido los Moros desde que se hallan detenidos allí, que son muy crecidos, y asi quiero que soliciteis la indemnización pues los Moros no tienen mas que vos que miréis por ellos": Cassen Reisi to J.M. González Salmón, Cádiz, 14 November 1793, AHN, Estado, leg. 5803 . 
do justice to you and restore your brigantine." Both Ibn Utman and the captain thought of the consul as the Moroccans' only friend. ${ }^{208}$

González Salmón informed his superior, the Secretary of State, of the complaints from the governor of Rabat, the captain, and Cassem and Taib Reisi. He shared their fear that the brigantine could be ruined "at the present season through the lack of shelter at that anchorage." ${ }^{209} \mathrm{He}$ also agreed with them on the urgent need for a solution so as to

satisfy those people and avoid unpleasant consequences, such as Bargas himself has already suggested, though we are aware that they are in no position to threaten us, nor will this case lead to a breach for the time being. All in all, we should not incommode ourselves in the least in view of the reasons of policy and convenience that prevail in these circumstances. ${ }^{210}$

But the consul did not believe that Muley Sliman would declare war on Spain. ${ }^{211} \mathrm{He}$ assumed it was an exaggeration arising from the unceasing flow of complaints from the merchants of Rabat, who might have "put pressure on the sultan to satisfy them by issuing such an order; especially when, as now, he enjoys the favor of some subjects who support his faction."212 The vice consul agreed: "Prince Muley Soliman has given repeated proofs of his sincere feelings for us and his wish to retain our friendship. It is very doubtful that he has given Ben Otoman the orders that the purser describes in his letter, of which we have heard absolutely nothing here." Still, he tried to find out what orders Ibn Utman might have received. While the affair would not "interrupt the good harmony that now exists between the two nations," there was a risk so long as

208 He added, "Send my greetings to Consul Juan Manuel Salmón”: Taib Reisi to Cassem Reisi, Ceuta, 18 November 1793, AHN, Estado, leg. 4331.

209 J.M. González Salmón to Duke of La Alcudia, Cádiz, 29 November 1793, AHN, Estado, leg. 5803 .

210 “...[dejar] complacidas ha aquellas gentes, y evitar conseqüencias desagradables, como ya las da a entender el mismo Bargas, aunque no se nos oculta de que no se hallan en estado de amenazarnos ni que llegue el caso de un rompimiento por ahora, con todo no nos combiene tampoco indisponernos en lo mas leve por las razones políticas y de combeniencia que militan en las actuales circunstancias": J.M. González Salmón to Duke of La Alcudia, Cádiz, 3 December 1793, AHN, Estado, leg. 5803.

211 J.M. González Salmón to Duke of La Alcudia, Cádiz, 10 January 1794, AHN, Estado, leg. 5803 .

212 J.M. González Salmón to Duke of La Alcudia, Cádiz, 24 December 1793, AHN, Estado, leg. 4331 . 
there was "pressure by the Moorish magnates of Rabat who are concerned with that ship." 213

The consul said of Cassem Reisi that

he displays very good conduct, as befits his birth, rank, and privileges in Barbary. And lately he enjoys much favor in Soliman's eyes, and in his native Rabat great acceptance and influence. All this forces me to keep him as happy as possible through courtesy and blandishments to soften his impatience. I will also do him some favor before he leaves, to maintain his devotion to us and gain the future advantages that his good opinion may bring. ${ }^{214}$

In view of Cassem Reisi's influence in Rabat it was best to keep him as an ally, so that everything possible was done to help him succeed in his suit. ${ }^{215}$ When several months later Reisi planned to go to Madrid to plead his cause, González Salmón repeated that "this Moroccan is one of the most distinguished men of that city [Rabat]," and "through his character and kinship with the chief holy man of that province he enjoys much esteem in Prince Muley Soliman's eyes, while his conduct and good behavior deserve every attention." He recommended that the Secretary of State receive him warmly.216

As we noted above, the consul was in favor of returning the brigantine and its cargo to the Moroccans so as to convince them that, in spite of Spain's "having very just cause for declaring it a legitimate prize, we make them this gift out of pure generosity." He feared, however, that the step would be seen not as deference but as a way to avoid reprisals against Spaniards. Should any take place, a precedent would be established that might recur for any reason, "whenever

213 A. González Salmón to J.M. González Salmón, Tangier, 2 January 1794, AHN, Estado, leg. 5803 .

214 "[S]e maneja con la conducta mas pausible, que esta es proporcionada a su Nacimiento, qualidad, y prerrogativas que obtiene en Berberia, y últimamente que disfruta mucha consideración en el concepto de Soliman, y que en Rebat de donde es natural goza de la mayor aceptación e influxo, todo lo que me obliga a conservarlo gustoso en lo que cabe por medio del buen trato y finezas con que procuro suavizar su impaciencia, y a demás pienso hacerle algún agasajo antes de su partida, a fin de mantenerlo a nuestra devoción, y conseguir las ventajas ulteriores que puede proporcionar su valimiento." Still, he thought that Reissi's complaints about the abuses against the brigantine's crew in Ceuta "may be greatly exaggerated": J.M. González Salmón to Duke of La Alcudia, Cádiz, 29 November 1793, AHN, Estado, leg. 5803.

215 J.M. González Salmón to Duke of La Alcudia, Cádiz, 15 November 1793, AHN, Estado, leg. 5803 .

216 J.M. González Salmón to Duke of La Alcudia, Cádiz, 14January 1794, AHN, Estado, leg. 5803. 
they imagine that they could gain advantage by it." Counter-reprisals against Moroccans in Spain would not work: "this is no way to calm people's spirits, so I believe the best course is to cut off any motive for resentment at its root." A decision should be made quickly: "if [the ship] is to be returned let it happen at once, so the Moors will not think it is the result of their violent protests, but rather a condescension that we wish to offer them."217 While he considered the Moroccans fanatics, he hoped to placate them as far as possible while not bending to their threats:

We shall not tolerate their notions or whims, because otherwise - if they realized that we needed their friendship or were desperate for it - they would become insufferable and would provoke us at every moment. ... The people we are dealing with have a tradition of inconstancy and perfidy. Knowing Muley Soliman's character I do not expect him to declare against us of his own volition, but I do fear that suggestions from his vassals may cause him to act. ${ }^{218}$

As the affair grew more serious the Spanish monarch ordered that the decision taken by the Minister of the Treasury in Ceuta be reviewed by the Council of War, while the Moroccans be informed and made to understand "the fairness and solemnity with which their petitions will be decided."

Meanwhile Sultan Muley Sliman wrote to Vice Consul Antonio González Salmón to express interest in the case. ${ }^{219}$ The recipient, following orders from the Spanish king and his brother the consul, told the ruler that he "may be persuaded of the fairness and seriousness with which his petitions will be

217 J.M. González Salmón to Duke of La Alcudia, Cádiz, 24 December 1793, AHN, Estado, leg. 4331.

218 " $[\mathrm{N}]$ o se les tolerará sus voluntariedades ó caprichos, porque de otra manera, y si comprehendiesen que necesitábamos de su amistad, ó la apetecíamos con ahínco se harían insufribles, y cada instante nos provocarían. ... [S]e trata con unas gentes que son el dechado de la inconstancia y perfidia, bien que no espero del carácter de Muley Soliman se declare contra nosotros de su motu proprio, pero si, recelo que las sugestiones de sus vasallos lo hagan resolver." It was a matter of "avoiding an open breach; and at the same time the Moors must know that their threats do not frighten us nor turn us from what we think right. For to contain the Moors' pride (which they usually possess) it is essential to let them know that while we love peace we do not fear war": J.M. González Salmón to Duke of La Alcudia, Cádiz, 10 January 1794, AHN, Estado, leg. 5803.

219 Muley Sliman to A. González Salmón, 15 December 1793. A. González Salmón to J.M. González Salmón, Tangier, 27 January 1794. J.M. González Salmón to Duke of La Alcudia, Cádiz, 14 February 1794, AHN, Estado, leg. 5803. 
resolved on our side; which has also been hinted to Muley Absalem and the other magnates who surround him, so they will no longer listen to the insidious suggestions that people from Rabat may make against us."220

Muley Sliman wondered whether the seizure "was in accord with the Laws of the Sea observed among all Christian nations, or not." The Spanish reply reassured him: "We knew from your reply that the detention followed the proper rules."221 The sultan rejoiced that the crewmen had been set at liberty, "because you have acted entirely rightly and justly with something that is ours. And this is what you have always observed, while your friendship toward us has been constant since the lifetime of our father (may he rest in God's peace), and now for our part we will continue the same, with God's help."222

We do not know how the affair ended, but the essential point is that channels of communication existed between Moroccan notables (provincial and military governors and merchants) and consular representatives of Spain that allowed for negotiating disagreements. While tensions existed, these channels helped to solve conflicts that arose between the two countries. Each side tried to persuade its own ruler by all possible means to intervene and find a solution satisfactory to all, even while individual interests were fiercely defended in every case.

\subsubsection{Alrahez Ben Alfaraed (1794)}

Alrahez Ben Alfaraed was detained by the governor of Ceuta for an unpaid debt of fifty pesos fuertes. The sultan's brother took an interest in his case and wrote to the governor:

I understand that in that presidio there is a Muslim who wishes to leave in order to live among Muslims, but is detained because he owes a sum of money amounting to fifty pesos fuertes. If this is true I am forwarding a letter from Consul Antonio Salmón, who will arrange to collect that amount from me to put the Muslim at liberty. But if the man does not want to come to this country let his debt not be paid; this is my decision.

220 A. González Salmón to J.M. González Salmón, Tangier, 27 January 1794. Similar sentiments were conveyed to the governor of Rabat: A. González Salmón to J.M. González Salmón, Tangier, 16 February 1794, AHN, Estado, leg. 5803 .

221 Muley Sliman to A. González Salmón, 5 January 1794. J.M. González Salmón to the Duke of La Alcudia, Cádiz, 11 March 1794, AHN, Estado, leg. 5803.

222 Translated letter from Muley Soliman to J.M. González Salmón, 5 February 1594, AHN, Estado, leg. 5803 . 
The Muslim is named Alrahez Ben Alfaraed. For this matter we have sent our interpreter Casem to that presidio [Ceuta]. ${ }^{223}$

His case was not unique, because we know that there were other Moroccans in Ceuta at the time but not why they were living (or held) there. The governor of Tangier told his counterpart in Ceuta that "any Moors who are in that [city] who wish to come here [to Morocco] will be well received; as for those who do not wish it, may God help them."224

\subsubsection{Ziuziu (1795)}

Almost all we know of Ziuziu, a resident of Tetouan, is contained in a letter from his father, Abdelkrim Ziuziu of the same city, to J.M. González Salmón, whom he calls his friend. ${ }^{225} \mathrm{He}$ asks him to forward an attached letter "to my son who is in Cádiz or Madrid, so that by God's grace I may receive an answer by your hand." The father was involved in a lawsuit with Benito Patrón of the Spanish company in Casablanca: it concerned a matter of business in Mazagan that he had been unable to resolve through either the commercial tribunals or the consulate ("I begin to see that I cannot settle it unless the matter reaches the King of Spain"). He claimed to be the victim of an injustice, offering as proof "the documents that show my right against his, signed by our scribes and judge and declared legal by the consuls at Rabat and Salé." He had sent the documents to "my son in Madrid so that he may sue the aforementioned Patrón." The day before leaving for Madrid the son had written two letters. The first was to Hach Mohamet Bel-Larosy, Pasha of Doukkala, asking him to persuade Prince Muley Ychem to write to the Spanish monarch recommending Benito Patrón. The prince refused, because he was displeased with the actions of the Cádiz-based company; but the Pasha sent Ziuziu (the son) the letter in

223 "[T] $]$ engo entendido que hay en esa Plaza un Musulman el qual quiere salir para retirarse a vivir entre los Musulmanes; pero se halla impedido por estar debiendo un cantidad de dinero, eso es cinquanta Pesos fuertes. Si es verdad eso, os remito una Carta del Consul Antonio Salmon, el qual se encarga de tomar de mi el dinero de la dicha cantidad para la libertad de dicho Musulman. Pero si dicho hombre no quiere retirarse a este pays, no se pague por el la citada deuda, pues esta es mi voluntad: El tal Musulman llamase Alrahez Ben Alfaraed. Para estos asuntos hemos embiado a esa Plaza nuestro interprete Casem": translation of an Arabic letter dated 17 July 1794. The translator assumes it comes from Muley Soliman's brother from the initials "L.S.," although he states that the seal is illegible: AHN, Estado, leg. 5807, Exp. 9 .

224 Letter from the governor of Tangier to the Count of Santa Clara, Tangier, 20 July 1794, A HN, Estado, leg. 5807, Exp. 9.

225 They belonged to a prominent merchant family in Tetouan: see a few references in Marín Niño, "Tetuán en la literatura colonial española." 
the prince's name without the latter's knowledge, so the letter was false. Ziuziu accused Patrón of lying: "He simply invents whatever he likes, to deceive and achieve his ends ... while he follows his own ideas, always using falsehoods, toward both the Moorish and the Christian kings." ${ }^{226}$ We know nothing of Ziuziu's efforts at the Court in Madrid, but it seems that matters did not go well for him; perhaps for that reason, his problems after his return to Morocco led to his imprisonment. In early 1797 the Spanish consul in Morocco intervened on his behalf before Muley Sliman, asking that he be set at liberty, and later expressed his thanks "for having the Moor Ziu Zin set free in response to Your Excellency's declaration in his favor."227

\subsubsection{Mohamed Ben Muchafi (1796)}

A merchant from Rabat, Sidi Mohamed Ben Muchafi, ${ }^{228}$ wrote in 1796 to the Secretary of State, who was then Manuel Godoy, "the Prince of Peace." He introduced himself as a resident of Cádiz who had also lived in Seville. He wished to be charged only half of the usual export duties for ten quintales of cochineal, and hoped his request would be granted because "no one of our nation has failed to obtain what favors he asked from that royal court. This fact is well known to our sovereign and the whole royal family, who all praise Your Excellency's generosity." To inflate his own merits he added that in Morocco he had quarreled with a Spanish captain "who, according to the laws of our kingdoms, should have been beheaded; however my sovereign, out of deference to the Spanish nation, did not wish to proceed against him or exile him from his domains." ${ }^{29}$ An Arabic interpreter at court, Elias Sidiac, found Muchafi's letter "very confused and written by an ignorant man; I have barely been able to understand it and extract its meaning." He suggested that the writer "come in person to express himself better."230 We do not know how the story ends, only that the Secretariat of State forwarded the matter to the Treasury - though naming the quantity of cochineal as two hundred quintales rather than ten. ${ }^{231}$

\footnotetext{
226 J.M. González Salmón to the Prince of Peace, Cádiz, 13 November 1795, AHN, Estado, leg. 4335 .

227 J.M. González Salmón to the Prince of Peace, Cádiz, 13 January 1797; Prince of Peace to J.M. González Salmón, San Lorenzo de El Escorial, 31 December 1796, AHN, Estado, leg. 4338.

228 He also appears as Muhamet/Mohamet Ben Majamet Micari.

229 Document dated 22 March 1796, AHN, Estado, leg. 5818.

230 Elias Sidiac, Madrid, 4 April 1796, AHN, Estado, leg. 5818.

231 Report dated 8 April 1796, AHN, Estado, leg. 5818.
} 
We have seen how the ${ }^{1767}$ Treaty of Peace, Friendship, and Trade between Spain and Morocco granted almost total freedom to Moroccan merchants to engage in commerce in Spanish cities and ports. It is also true, however, that such liberty was somewhat limited when Moroccans created problems. Both governments feared damage to the excellent relations between their two countries.

Still, the number and importance of those incidents should not be exaggerated. ${ }^{232}$ The great majority of Moroccan tradesmen presented no difficulties at all and remain undocumented or perhaps mentioned only in passing, a probable sign of good behavior but one that tells us no more about them. The same can be said of Spanish businessmen and sailors who conducted their affairs in Moroccan cities and ports, though we have no monographic study of the subject. 233

Of course the great majority of merchants, both Spanish and foreign, tried to evade the health regulations as often as they could and also engaged in smuggling - in the latter activity Moroccans were frequent "straw men" for European traders. There were numerous incidents of fraud, theft, etc., among this collective as well, whatever their nationality. Bearing this in mind we will avoid the impression that Moroccans were particularly guilty.

It is most important to stress that a merchant colony was formed whose members knew exactly where and to whom to appeal for solutions to their problems, even though many of them claimed ignorance of the Spanish laws, cases, and mechanisms required for negotiation. They appealed to magistrates, governors, admirals, boards of trade, Spanish consuls and vice consuls, ministers, and especially Secretaries of State (who often documented their contacts with Moroccan merchants) and the monarchs themselves, usually through written petitions. They entered into alliances with Spanish and foreign businessmen whose protection could sometimes help them.

Their frequent appeals to the Secretary of State and the monarch implied stays of varying length in Madrid or one of the royal summer residences; that, and Moroccans' insistence that their petitions be heard, developed into a serious problem. Repeated orders that they not come to court proved futile. Local

232 In fact, we have dozens of covers of reports on Moroccans that preserve only the man's name, without any date or place. The cases must have been opened on account of some problem, but for the moment we know nothing more about them.

233 In those cases as well, authorities on both sides limited the damage in any way they could. 
authorities in different cities and ports faced the same issue, including Spain's consul general in Morocco, especially when he traveled to Cádiz. A partial solution began to emerge during Spain's war with England in 1797-1802, as we shall see in the following chapter. 